\title{
Ots
}

\section{Oreshoot Zoning in the Carlin-type Betze Orebody, Goldstrike Mine, Eureka County, Nevada}

By Stephen G. Peters ${ }^{1}$, Gregory C. Ferdock ${ }^{2}$, Maria B. Woitsekhowskaya ${ }^{1}$, Robert Leonardson ${ }^{3}$, and Jerry Rahn ${ }^{3}$

Open-File Report 98-620

1998

This report is preliminary and has not been reviewed for conformity with U.S. Geol ogical Survey editorial standards or with the N orth American Stratigraphic Code. Any use of trade, product, or firm names is for descriptive purposes only and does not imply endorsement by the U.S. Government.

\section{U.S. DEPARTMENT OF THE INTERIOR}

\section{U.S. GEOLOGICAL SURVEY}

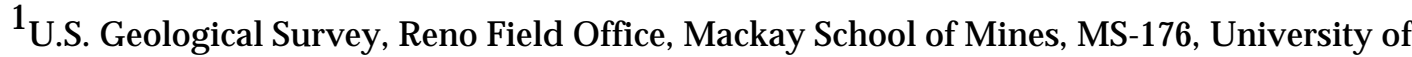
Nevada, Reno, N evada 89557-0047

2Department of Geological Sciences, Mackay School of Mines, University of Nevada, Reno, Nevada 89557-0047

3Mine Geology Department, Barrick Goldstrike Mines, Inc., P.O. Box 29, Elko, Nevada 89803. 


\title{
Oreshoot Zoning in the Carlin-type Betze Orebody, Goldstrike Mine, Eureka County, Nevada
}

\author{
by \\ Stephen G. Peters ${ }^{1}$, Gregory C. Ferdock ${ }^{2}$, Maria B. Woitsekhowskaya ${ }^{1}$, Robert \\ Leonardson ${ }^{3}$, and Jerry $\operatorname{Rahn}^{3}$ \\ ${ }^{1}$ U.S. Geological Survey, Reno, Nevada. ${ }^{2}$ Mackay School of Mines, University of Nevada, \\ Reno, Nevada. ${ }^{3}$ Barrick Goldstrike Mines, Inc., Elko, Nevada
}

\begin{abstract}
Field and laboratory investigations of the giant Betze gold orebody, the largest Carlin-type deposit known, in the north-central Carlin trend, Nevada document that the orebody is composed of individual high-grade oreshoots that contain different geologic, mineralogic, and textural characteristics. The orebody is typical of many structurally controlled Carlin-type deposits, and is hosted in thin-bedded, impure carbonate or limy siltstone, breccia bodies, and intrusive or calc-silicate rock. Most ores in the Betze orebody are highly sheared or brecciated and show evidence of syndeformational hydrothermal deposition. The interplay between rock types and pre- and syn-structural events accounts for most of the distribution and zoning of the oreshoots. Hydrothermal alteration is scale dependent, either in broad, pervasive alteration patterns, or in areas related to various oreshoots. Alteration includes decarbonatization ( decalcification) of carbonate units, argillization (illite-clay), and silicification. Patterns of alteration zoning in and surrounding the Betze orebody define a large porous, dilated volume of rock where high fluid flow predominated. Local restriction of alteration to narrow illite- and clay-rich selvages around unaltered marble or calc-silicate rock phacoids implies that fluid flow favored permeable structures and deformed zones. Gold mainly is present as disseminated sub-micron-sized particles, commonly associated with As-rich pyrite, although one type of oreshoot contains micron-size free gold.
\end{abstract}

Oreshoots form a three-dimensional zoning pattern in the orebody within a WNWstriking structural zone of shearing and shear folding, termed the Dillon deformation zone (DDZ). Main types of oreshoots are: (1) rutile-bearing siliceous oreshoots; (2) illite-claypyrite oreshoots; (3) realgar- and orpiment-bearing oreshoots; (4) stibnite-bearing siliceous oreshoots; and (5) polymetallic oreshoots. Zoning patterns result from paragenetically early development of illite-clay-pyrite oreshoots during movement along the DDZ, and subsequent 
silicification and brecciation, associated with formation of the realgar- and orpiment-bearing, and stibnite-bearing oreshoots. Additional shear movement along the DDZ followed. Polymetallic oreshoots, which contain minerals rich in $\mathrm{Hg}, \mathrm{Cu}, \mathrm{Zn}, \mathrm{Ag}$, and native $\mathrm{Au}$, were the last ores to form and overprint most earlier oreshoots.

Ore textures, gouge, phyllonitic rock, alteration style, and previously documented isotopic and fluid-inclusion data, all indicate a weakly to moderately saline fluid that ascended and cooled during structural displacements. Changing conditions, due to waterwall rock reactions and $\mathrm{P}-\mathrm{T}$ changes during deformation, are probably responsible for fluid variation that resulted in zoning of the different oreshoots during dynamic interaction of the Au-bearing fluid with the wall rock. This investigation indicates that isolated $\mathrm{As}_{-}-\mathrm{Sb}-$, and $\mathrm{Hg}$-rich ores are separate parts of a larger single gold system. This large gold system was contemporaneous with post-Jurassic brittle-ductile deformation, on the basis of deformed mineralized pods of the Jurassic Goldstrike pluton, and large-scale hydrothermal flow, and together they appear to be an integral part of the formation of some Carlin-type gold deposits in north-central Nevada.

\section{INTRODUCTION}

The Betze gold orebody is one of more than 50 gold deposits along the Carlin trend, Nevada (Fig. 1), which together are conservatively estimated to contain more than 100 million oz ( 3,200 tonnes) of gold (Christensen, 1996; Teal and Jackson, 1997). Exploration activity in the Betze area began in 1962 and mining on the Goldstrike property, which took place between 1974 and 1986, exploited oxide gold orebodies in largely siliceous host rocks. The deep hypogene Betze and Deep Post orebodies were discovered in 1987 and production began by Barrick Goldstrike Mines Inc. and Newmont Mining Co. Ltd. shortly thereafter. Over 10 million oz gold ( $\sim 325$ tonnes gold) have been produced to 1998. The Betze orebody contains over 30 million oz ( 1,000 tonnes) gold in hypogene ores averaging about $0.2 \mathrm{oz}$ $\mathrm{Au} / \mathrm{t}(6.4 \mathrm{~g} \mathrm{Au} / \mathrm{t})$. Mining rates at the Goldstrike Mine have been between 300,000 to 500,000 tonnes per day, of which between 30,000 to 60,000 tonnes are ore.

Carlin-type deposits are characterized by relatively uniform, low gold grades (Arehart, 1996); however, recent open pit exposures in deep hypogene parts of the Betze orebody and in other gold deposits along the Carlin trend suggest that some orebodies are composed of distinct high-grade oreshoots that are zoned complexly in three dimensions (Peters, 1996, 1997a). Stratabound, structurally controlled, and complex orebodies were noted along the Carlin trend by Christensen (1993). In structurally controlled type deposits, such as the Betze orebody, oreshoots contain micro- and mesoscopic-scale deformation fabrics and textures that can be linked directly with paragenetic development of the orebody. Geometric and structural characteristics of oreshoots in the Betze orebody indicate that some

parts of the orebody were formed synchronously with deformation and have spatial and genetic relations to folds and faults.

The results presented in this paper suggest that each oreshoot type in the Betze orebody is characterized by a combination of rock type, ore- and alteration-mineral 
assemblage, and structural fabric. Understanding the nature of oreshoots and predicting their location and shape has always been a major concern of economic geologists (Penrose, 1910; Hulin, 1929; Blanchard, 1931; McKinstry, 1941, 1955; Peters, 1993a). Oreshoots usually indicate zones of dilation and high fluid flow, as well as unique rock chemistry. They are characterized by higher metal content than that in adjacent mineralized rocks. The mass of most gold-bearing oreshoots in mesothermal and epithermal vein deposits ranges between 2 x $10^{4}$ and $1 \times 10^{6}$ tonnes with grades generally greater than $0.1 \mathrm{oz} \mathrm{Au} / \mathrm{t}(3.1 \mathrm{~g} \mathrm{Au} / \mathrm{t})$ (Peters, 1993b). Oreshoots generally have a heterogeneous grade distribution, such that they are thicker and richer in the center or in a lobe along one side. Oreshoots rarely terminate abruptly, commonly at geologic features, or their margins may taper in thickness or grade to assay cut-offs. A characteristic feature of many oreshoots is their unique internal geologic complexity and mineralogy that reflect multiple episodes of formation. Oreshoots in the Betze orebody have characteristics similar to most other oreshoots, but the large size of the entire orebody and the multiple types of oreshoots are unusual. Documentation and analysis of this oreshoot variation in the Betze orebody is important to understand Carlin-type deposits because it is the largest gold orebody along the Carlin trend. Differentiating oreshoot types also may prove to be important in ore sorting and mixing prior to processing in underground operations.

\section{PREVIOUS WORK}

Geologic investigations of ore deposits along the Carlin trend and of the Betze orebody have been numerous (Teal and Jackson, 1997), but the origin of these deposits is still in dispute (see Hofstra and others, 1991; Ilchik and Barton, 1997; Arehart, 1996; Peters and others, 1996; Tosdal, 1998). The geology of the Goldstrike Mine area has been described in some detail by Sampson (1993), Volk and Lauha (1993), Campbell (1994), Volk and 
others (1996), Peters (1996, 1997a), and Leonardson and Rahn (1996). Additional documentation and summaries of the geology and ores of the area were given by Bettles (1989), Arehart and others (1993b,c), Lauha and Bettles (1993), Thoreson (1993), and Smith and Sharon (1994). These workers have described a shallow WNW-plunging, structurally complex orebody that is hosted in Paleozoic sedimentary rocks along a diorite contact zone. The gold ores are typified by disseminated gold-bearing arsenian pyrite. Much of the Betze orebody is hosted in breccia (Peters and others, 1997), which is common in many Carlin-type deposits (Williams, 1992, 1993), particularly in orebodies of the north-central Carlin trend (Clode, 1993; Griffin and others, 1993; Leach, 1993).

Paragenetic study of ores in the Betze orebody and its associated orebodies have been conducted by Berry (1992), Bettles and Lauha (1991), Arehart and others (1993a), Lamb (1995), and Ferdock and others $(1996,1997)$, and it contains mineral sequences similar to those proposed for most other Carlin-type deposits (see Radtke, 1985; Kuehn, 1989; Bakken and Einaudi, 1986; Madrid and Bagby, 1986; Kuehn and Rose, 1992, 1996; Groff, 1995). These studies interpreted one or more gold events and recognized mineralogically distinct types of ore, but spatial relations between the various types of ore were not well established. Mineralogically distinct types of ore have been identified in most Carlin-type deposits, and temporal relations among these ore types have been proposed (Hausen and Kerr, 1966, 1968; Madrid and Bagby, 1988); however, the concept of distinct, high-grade, oreshoots in Carlintype deposits and their spatial and genetic relation to one another has not been well understood (see also Radtke and others, 1972a, b, 1974b, 1977; Radtke and Dickson, 1975).

\section{METHODS OF STUDY}

Geologic bench and broken ore pit bottom mapping at 1 in $=50 \mathrm{ft}$ and at 1 in $=5 \mathrm{ft}$ (1:600 and 1:60) scales, supplemented by drill-core and drill-chip logging, provided the basis for observations made in this paper. Blast hole assays that were collected for mine planning and metallurgical purposes on the $4,800 \mathrm{ft}$ elevation level were compiled and were hand contoured. Paragenetic relations in the Betze deposit were determined from mine-scale mapping, from slabbed hand specimens, and from thin section petrology as well as SEM studies. Scanning-electron-microscope work was conducted at the U.S. Geological Survey, Menlo Park, and at the Mackay School of Mines, Reno. XRD analysis was conducted at Barrick Goldstrike and at Mackay School of Mines. Illite crystallinity estimations followed the methods of Kirsch (1991) and used both the half peak width and area measurements of $<2-\mu \mathrm{m}$ clay material. Geochemical modeling was conducted, as part of a larger study (Woitsekhowskaya and Peters, 1998), using the HCh program of Schvarov (1976). Geochemical analysis of ores was done by the U.S. Geological Survey laboratories, Denver, and also was contracted through the Nevada Bureau of Mines and Geology, Mackay School of Mines, Reno.

\section{REGIONAL GEOLOGIC SETTING}




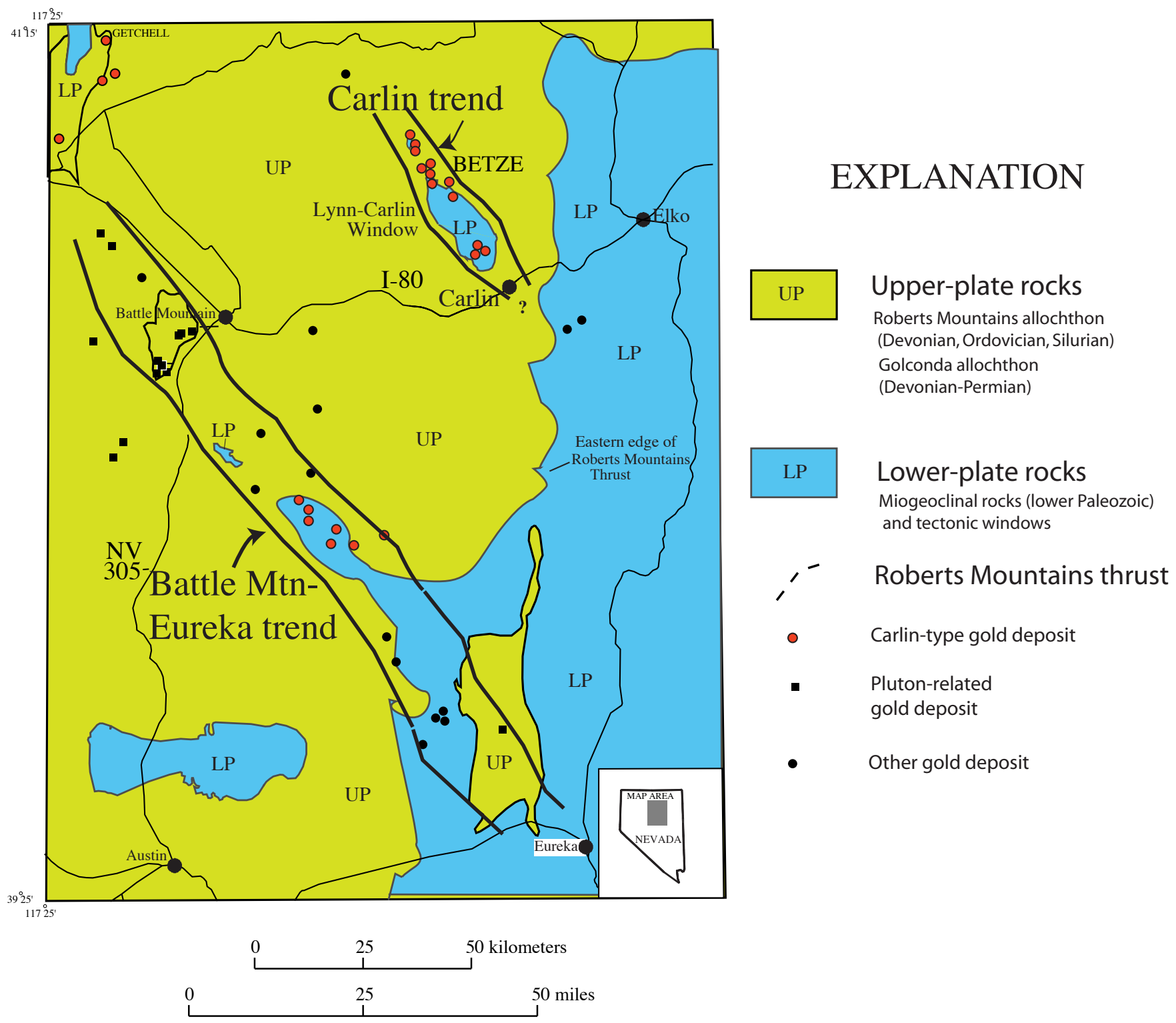

Figure 1. Gold deposits and simplified hypothetical distribution of allochthons and tectonic windows in north-central Nevada. The Carlin trend lies along the Carlin-Lynn window. Other windows through the Roberts Mountains allochthon also have associated gold deposits. Some gold deposits are related to porphyry and gold-skarn deposits (many are called distal-disseminated Ag-Au deposits); others are sedimentary rock-hosted (Carlin-type) gold deposits. Other deposits are volcanic or unclassified sedimentary rock-hosted deposits. Note that Cenozoic and Mesozoic rocks are not shown and Basin and Range tectonism and geomorphology is not portrayed. Modified from Prihar and others (1996) and Lahren and others (1995). 
In the Carlin trend area, northern Nevada, early and middle Paleozoic, deep-water, siliciclastic sedimentary and volcanic rocks were thrust eastward approximately 75 to 200 $\mathrm{km}$ during the Late Devonian to Early Mississippian Antler orogeny (Roberts and others, 1958). These rocks compose the approximately 5-km-thick Roberts Mountains allochthon (Madrid and others, 1992), which lies upon coeval shallow-water, carbonate-rich rocks of the continental platform (Figs. 1 and 2, table 1). The two packages of rocks, the upper and lower plates, are separated by the Roberts Mountains thrust fault. The Golconda allochthon (Silberling and Roberts, 1962), consisting of uppermost Devonian to lower Upper Permian carbonate-rich turbiditic sands and basinal strata, was thrust on top of the continental margin and parts of the Roberts Mountains allochthon during the latest Permian and early Triassic. These tectonic events indicate crustal thickening accompanied by deformation and are generalized and combined with other, subsequent tectonic events in the region on table 1 as deformation events $\mathrm{D}_{0}$ through $\mathrm{D}_{4}$. Gold mineralization in the Carlin trend is interpreted to be either Late Cretaceous or early Eocene (Arehart and others, 1993c; Teal and Jackson, 1997), indicating that it would be synchronous with the Late Jurassic to Early Eocene SevierLaramide $\mathrm{D}_{3}$ tectonic event (table 1). A NE-trending lineament, the Crescent ValleyIndependence Lineament crosses the Carlin trend and is interpreted by Peters (1998) and by Theodore and others (1998) to have had geologic activity along it from the Late Paleozoic to the Middle Cenozoic, which overlaps the gold mineralizing time estimates of the Carlin trend (Fig. 2).

Sedimentary rock-hosted disseminated gold deposits in northern Nevada are spatially associated with tectonic windows through the Roberts Mountains allochthon or with structural highs beneath the allochthon (Roberts, 1960; 1966; Thorman and Christensen, 1991; Peters, 1997b,c). The Carlin trend is a northwest-trending belt of gold deposits near these windows (Fig. 1). The largest window in the Carlin trend area is the northwestplunging Lynn-Carlin window that hosts the Betze orebody and its associated deposits in its northern parts (Figs. 1, 2, 3A, B). Lower-plate rocks exposed in the southern part of the window (see Evans 1974a, b, 1980) consist of Ordovician and Cambrian(?) thick-bedded dolomite and thin-bedded limestone, massive, thick-bedded quartzite, and sandy dolomite (Figs. 3C,D). These rocks are overlain by Ordovician black to dark gray, fine-grained, thickbedded to massive dolomite with bioclastic debris and chert.

Gold deposits mainly are hosted in the three upper units of the lower plate: (1) the Silurian and Devonian Roberts Mountains Formation, a silty laminated dolomitic limestone; (2) the Devonian unnamed limestone (D1) of Evans (1980), locally called the Popovich limestone, composed of platy, laminated, silty dolomitic and micritic limestone; and (3) the locally recognized Devonian Rodeo Creek unit (see Christensen, 1993), which consists of laminated mudstone, siltstone, siliciclastic and cherty rocks, with local limestone. Although gold is hosted in all these rock types, over 90 percent of the gold is present in a 350-m-thick stratigraphic interval encompassing the top and bottom of the Popovich limestone (Fig. 3C, D; see also Armstrong and others, 1997). Upper-plate rocks locally are mineralized and include rocks of the siliceous (western) assemblage of Evans (1980), which are generally assigned to the Ordovician Vinini Formation in the area of the Carlin trend (Madrid, 1987; Madrid and others, 1992), but also include Silurian and Devonian rocks (Barrick, unpub. data, 1996; Cluer and others, 1997). 


\section{Table 1. Generalized and combined tectonic events, Carlin trend area, northern Nevada}

\begin{tabular}{|c|c|c|c|c|c|}
\hline $\begin{array}{c}\begin{array}{c}\text { Deformation } \\
\text { event }\end{array} \\
\end{array}$ & Orogeny & $\begin{array}{l}\text { Approximate } \\
\text { time interval } \\
\end{array}$ & Tectonic activity & Mineralization & References \\
\hline$D_{0}$ & sedimentation & $\begin{array}{l}\text { Early and } \\
\text { Middle } \\
\text { Paleozoic }\end{array}$ & $\begin{array}{l}\text { volcanism, soft } \\
\text { sediment } \\
\text { deformation }\end{array}$ & $\begin{array}{l}\text { sedimentary } \\
\text { exhalative } \\
\text { deposits }\end{array}$ & $\begin{array}{l}\text { Roberts and others } \\
\text { (1958); Emsbo and } \\
\text { others (1997) }\end{array}$ \\
\hline$D_{1}$ & $\begin{array}{l}\text { Antler- } \\
\text { Humboldt }\end{array}$ & $\begin{array}{l}\text { Late Devonian } \\
\text { to earlyPermian }\end{array}$ & $\begin{array}{l}\text { Roberts Mountains } \\
\text { thrust, tight } F_{1} \\
\text { folding, and } \\
\text { subsequent orogeny } \\
\text { and sedimentation, } \\
\text { CVIL }\end{array}$ & $?$ & $\begin{array}{l}\text { Roberts and others } \\
\text { (1958); Madrid } \\
\text { and others (1992); } \\
\text { Saucier (1997); } \\
\text { Theodore and } \\
\text { others (1998) }\end{array}$ \\
\hline $\mathrm{D}_{2}$ & Sonoma-Elko & $\begin{array}{l}\text { Late Permian to } \\
\text { Late Jurassic }\end{array}$ & $\begin{array}{l}\text { Golconda thrust; } \\
\text { abundant } \\
\text { penetrative } \\
\text { shallow-plunging } \\
\text { NE- and } \mathrm{F}_{2} \mathrm{NW} \text { - } \\
\text { trending folds, } \\
\text { CVIL }\end{array}$ & ? & $\begin{array}{l}\text { Silberling and } \\
\text { Roberts (1962); } \\
\text { Silberling (1975); } \\
\text { Tomlinson (1990); } \\
\text { Ketner and Alpha, } \\
\text { 1992, and Ketner } \\
\text { and others, } 1993\end{array}$ \\
\hline$D_{3}$ & Sevier-Laramide & $\begin{array}{l}\text { Middle } \\
\text { Cretaceous to } \\
\text { Early Eocene }\end{array}$ & $\begin{array}{l}\text { WNW-striking } \mathrm{F}_{3} \\
\text { shear zones, } \\
\text { refolding, } \\
\text { plutonism, CVIL }\end{array}$ & $\begin{array}{l}\text { skarn and } \\
\text { mesothermal } \\
\text { veins, Betze } \\
\text { deposit }\end{array}$ & $\begin{array}{l}\text { Ketner (1987); } \\
\text { Thorman and } \\
\text { others }(1991 a, b)\end{array}$ \\
\hline $\mathrm{D}_{4}$ & $\begin{array}{l}\text { Basin and Range } \\
\text { extension }\end{array}$ & $\begin{array}{l}\text { Middle Eocene } \\
\text { to Early } \\
\text { Oligocene }\end{array}$ & $\begin{array}{l}\text { brittle basin and } \\
\text { range faulting, } \\
\text { volcanism, } \\
\text { plutonism, CVIL }\end{array}$ & $\begin{array}{l}\text { hot-spring } \\
\text { deposits }\end{array}$ & Seedorff (1991) \\
\hline
\end{tabular}

Note: The $D_{0}$ to $D_{4}$ designations are greatly simplified and do not represent the entire structural history of northern Nevada. Several orogenies, usually considered separate events, have been combined to reflect one time span. Additional events and structural fabrics, especially cleavages, are present and not noted above. This scheme was constructed to demonstrate fold relations in the Carlin trend and Betze orebody area. Folds interpreted to have taken place during each deformation event are designated in the text by the same subscript, such as $D_{2}$ folding would be $F_{2}$ folds, $D_{3}$ foldiing would be $F_{3}$ folds etc. CVIL, Crescent Valley-Independence Lineament (Peters, 1998). 
Gold mineralized rocks along the Carlin trend are concentrated along a series of NNW- and NE-trending, medium- to high-angle district-scale shear zones and faults (Figs. 2, 3B and 4). In addition, several WNW-striking, medium to shallow, NE-dipping shear folds have been recognized (Peters, 1997a, b, c). In the area around the Carlin trend the strikes of common shallow-plunging $\mathrm{F}_{2}$ (table 1) fold axes in both the lower- and upper-plate rocks can be grouped into two domains. Domain I contains a series of NE-SW-plunging fold axes, and Domain II is a local NNW-SSE-trending belt of fold axes with common NNW strikes (Fig. 4A). Domain I is most common in upper plate rocks outside of the Carlin trend. Domain II roughly coincides with lower-plate "windows," but also contains upperplate rocks, which have NNW-SSE-trending fold axes. This geometry has been interpreted by Peters $(1996,1997 \mathrm{c})$ to result from shear folding, where WNW-ESE-striking Late Jurassic to Early Eocene $\mathrm{D}_{3}$ shear zones (table 1) form $\mathrm{F}_{3}$ shear folds. These shear folds refolded and rotated original $\mathrm{F}_{2}$ folds from NE-SW to NNW-SSE orientations (Figs. 3A, 4B, C). This refolding and rotation resulted in the preponderance of NNW-SSE-plunging fold axes in the mineralized areas in Domain II, because the $\mathrm{F}_{2} \mathrm{NE}$-plunging fold axes were rotated by WNW-ESE-plunging $\mathrm{F}_{3}$ shear folds. The main $\mathrm{F}_{3}$ shear fold in the Goldstrike Mine is the Dillon deformation zone (designated as DDZ; Figs. 3A, 5A, 6A,B, and 7A,B,C), a zone of shallow, NE-dipping, WNW-ESE-striking brittle-ductile shear zones and WNWESE-plunging shear folds, which host the Betze orebody and is described by Peters (1996) and Leonardson and Rahn (1997). The DDZ and other WNW-trending $\mathrm{F}_{3}$ shear folds and shear zones within Domain II in the Carlin trend area (see Figs. 3A and 4C) are important features for interpretation of syndeformational Carlin-type gold ores, because structural fabrics and ore textures in the orebody should be aligned with, and related to, these $\mathrm{F}_{3}$ structures if mineralization were synchronous with $\mathrm{D}_{3}$ deformation.

\section{GEOLOGY OF THE GOLDSTRIKE MINE AREA}

Host rocks in the Betze orebody are altered and deformed. The Betze orebody in the Goldstrike Mine is surrounded by the upper Post and north Betze orebodies on the north and by the Deep Post orebody on the east side (Fig. 5). These contiguous orebodies have NNW trends and shallow SE plunges, parallel to fold axes in the Post anticline. The main Betze orebody, in contrast, has a WNW trend and a near horizontal plunge - parallel to the DDZ and the Betze anticline - although some extensions of the orebody have NNW orientations and the lower parts of the orebody are more irregular.

Rocks in the Goldstrike Mine area are upper-plate Ordovician through Devonian siliciclastic rocks of the Roberts Mountains allochthon, mostly assigned to the Vinnini Formation, and Devonian and Silurian lower-plate carbonate and siliciclastic rocks (Fig. 5). These rocks are in contact with the northern part of the Late Jurassic (158-Ma) Goldstrike stock and sill complex (Fig. 5), which also locally is mineralized (Bettles, 1989; Arehart and others, 1993a). Miocene Carlin Formation rocks and Quaternary alluvium also are present on the north and east sides of the mine (Fig. 5).

Sedimentary Rocks 


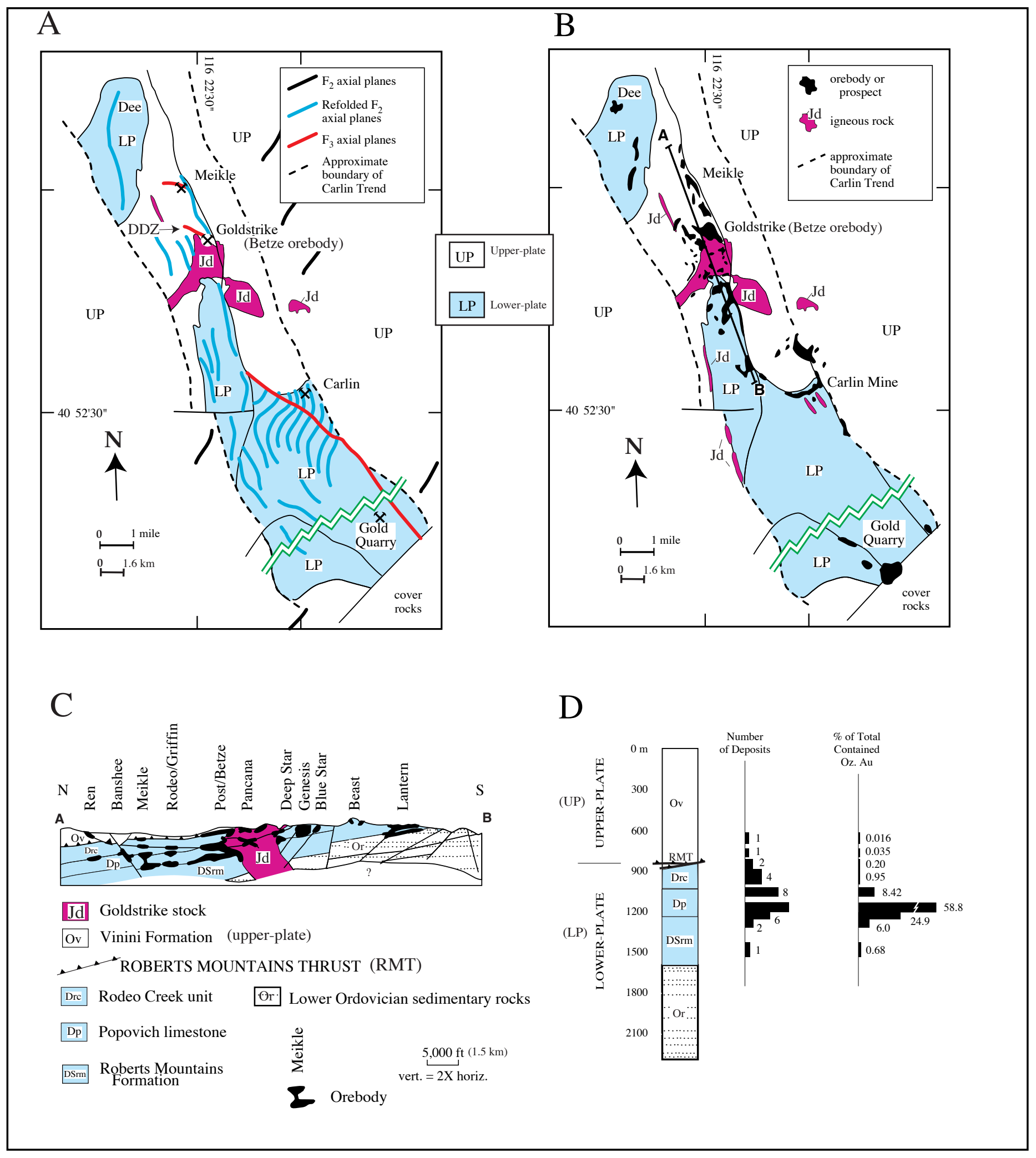

Figure 3. Relation of orebodies to structure and stratigraphy in the Carlin tend. (A) Generalized distribution of fold axial planes along the Carlin trend. The Betze orebody is hosted along a F3 shear fold [the Dillon deformation zone (DDZ)] in the Goldstrike Mine area. (B) Surface projection of grade thickness contours of gold orebodies shows a distribution along F2 axial planes of folds and associated faults, such as the Post Fault, and clusters at four centers: Dee, Meikle-Goldstrike, Carlin, and Gold Quarry Mine areas. (C) Idealized cross section A-A' from 3B, looking easterly, through the Goldstrike cluster of orebodies shows that most deposits are hosted in or near the Popovich limestone. (D) Graphs showing distribution of deposits, ounces of Au, and total contained ounces also showing major concentrations of gold ore near the Popovich limestone. Adapted from Peters and others (1997). 


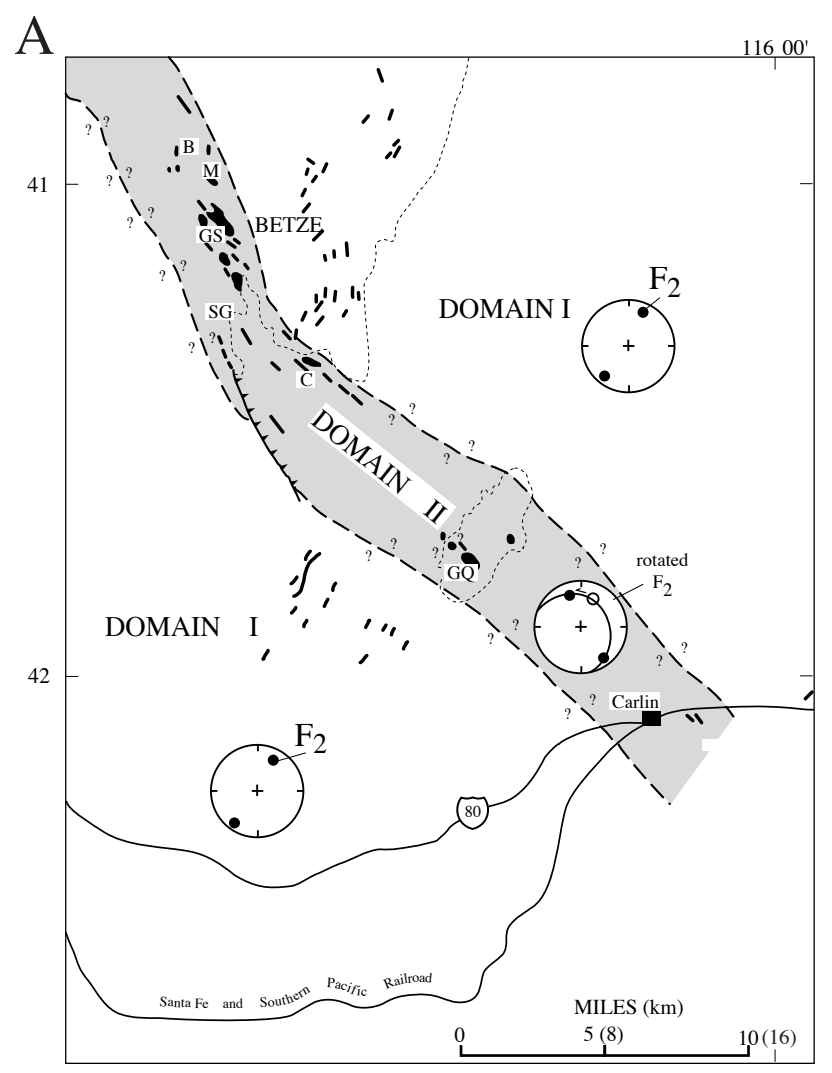

B
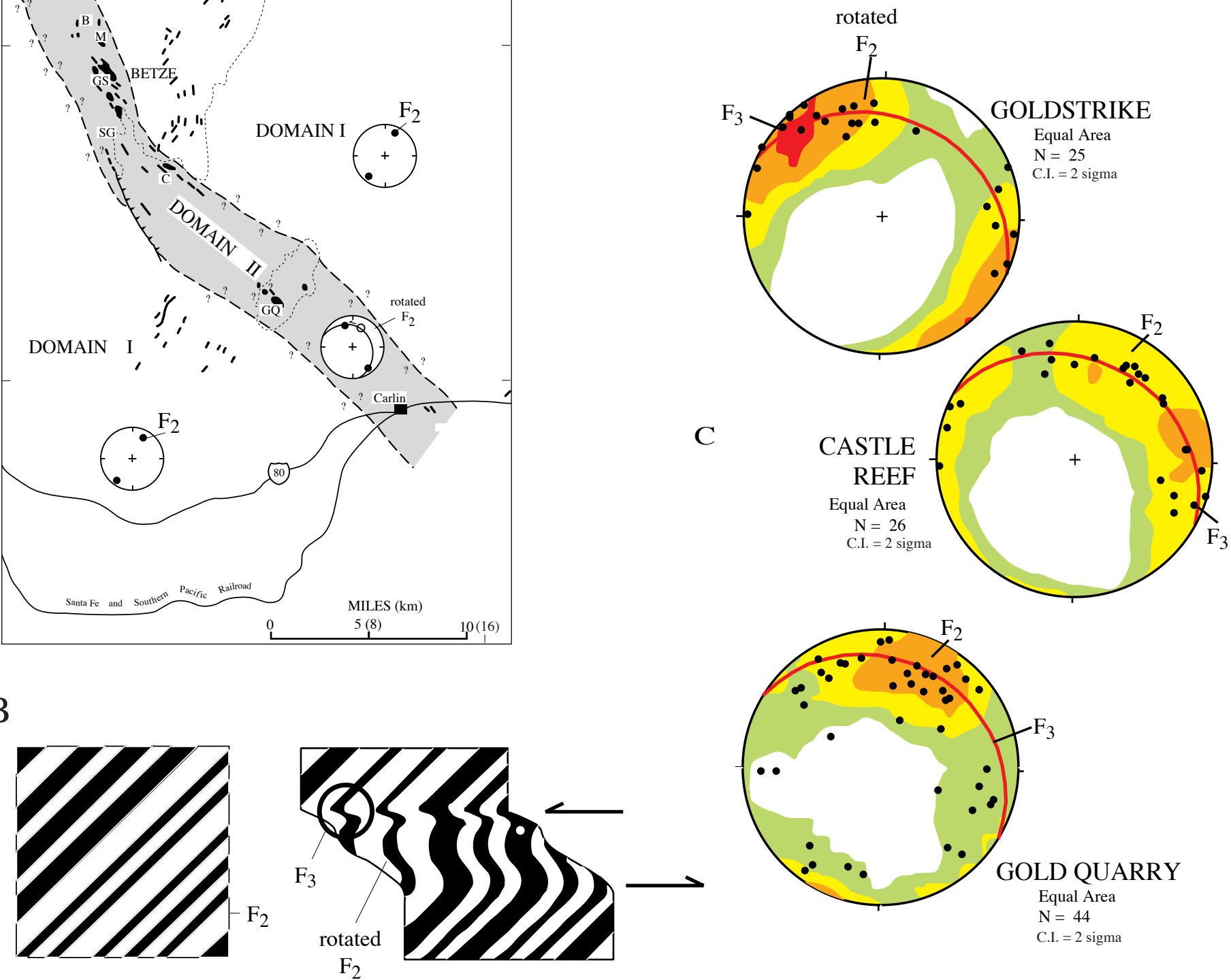

Figure 4. Structural elements and deformation model for the Carlin trend. (A) Structural domain map of the Carlin trend area, based on orientation of fold axes. Strikes of the shallow-plunging fold axes define two Domains: Domain I contains a series of shallow NE-SW-plunging fold axes;

Domain II, a local NW-trending belt of NW-trending fold axes. Domain II roughly coincides with the lower-plate "windows" and the Carlin trend, but some of the upper-plate rocks also are deformed. Small, short lines on map are fold axes from Evans and Theodore (1978). Other data (from S to N) from Dave Cole (oral comm., 1995), Evans and Cress (1972), Radtke (1985), Volk and Lauha (oral comm., 1994), Sampson (1993), and Evans and

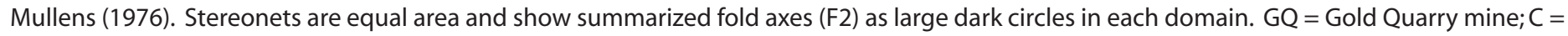
Carlin mine; SG = Star-Genesis mine; GS = Goldstrike Mine; M = Meikle mine; B = Bootstrap mine. Adapted from Peters (1996, 1997a, b, c). (B) Examples of shear zones forming folds. This shear fold model illustrates the deformation style that may have been present in the Carlin trend area, where WNW-striking shear zones form F3 shear folds that refold original F2 folds from NE-SW to NW orientations (adapted from Ramsey, 1980). (C) Stereographic plot of mesoscopic fold axes from the Goldstrike (GS), Castle Reef (south of C, Carlin Mine), and Gold Quarry area, Carlin trend, superimposed on Kamb contours of fold axes. Most NE-plunging fold axes are interpreted as F2, NW-plunging fold axes may be F2 that have been rotated by shear folding, which generated WNW-plunging F3 shear folds, like the Dillon deformation zone (DDZ). Plane approximate the F3 fold axis in each area. Contour values from Kamb contour plot indicated as C.I. $=2.0$ sigma from Stereonet v. 4.9.5, Absoft Corp. 


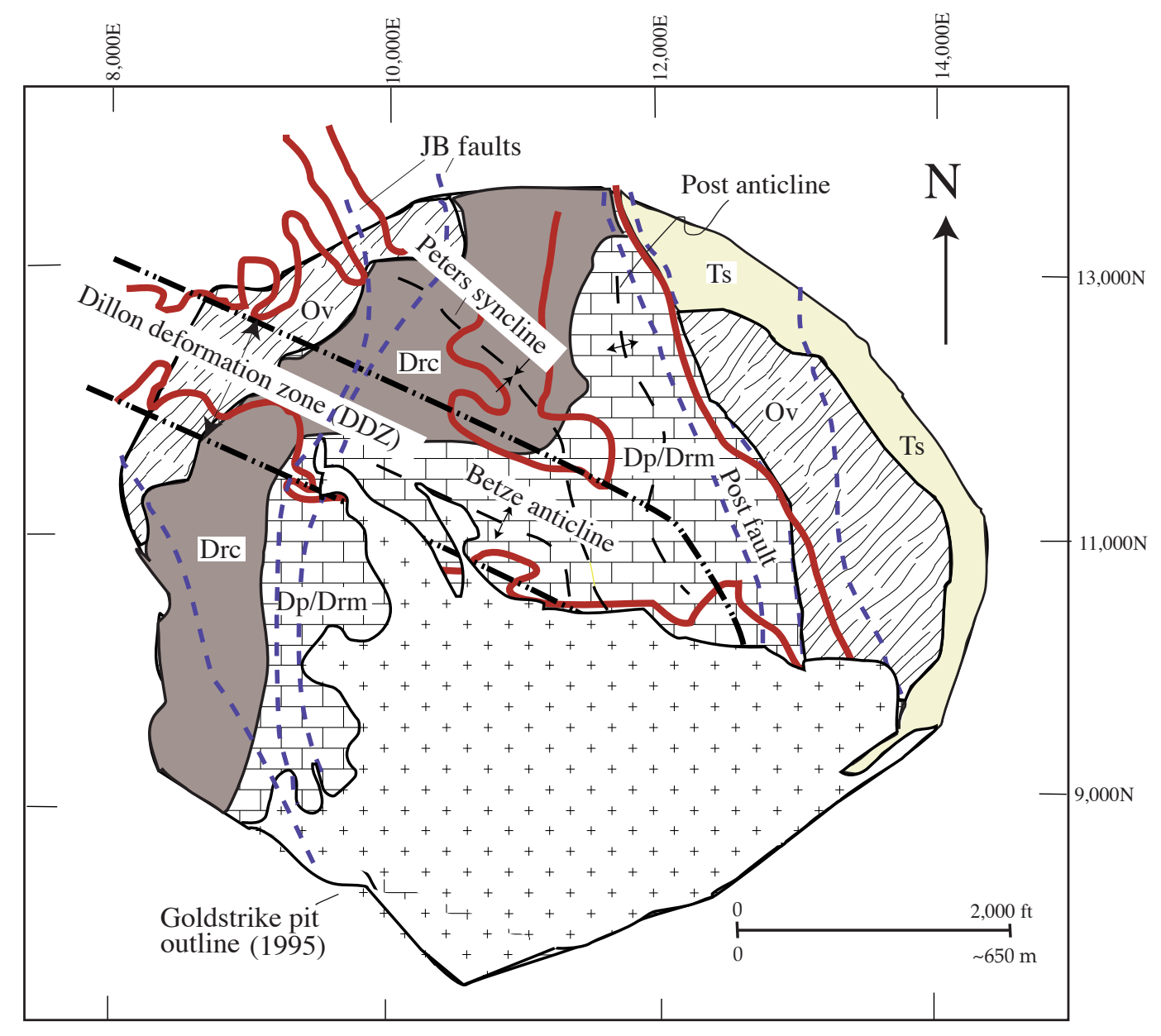

\section{EXPLANATION}

\begin{tabular}{|c|l}
\hline Ts & $\begin{array}{l}\text { Carlin Formation } \\
\text { (Tertiary) }\end{array}$ \\
\hline$+\mathrm{Jd} \cdot$ & $\begin{array}{l}\text { Goldstrike stock } \\
\text { (Jurassic) }\end{array}$ \\
\hline $\mathrm{Drc}$ & $\begin{array}{l}\text { Rodeo Creek unit } \\
\text { (Devonian?) }\end{array}$ \\
\hline Dp/Drm & $\begin{array}{l}\text { Popovich limestone and } \\
\text { Roberts Mountains Formation } \\
\text { (Devonian?) }\end{array}$
\end{tabular}

VOv' Vinini Formation

(Ordovician) (upper-plate)

A Anticline

* Syncline

1 Fault

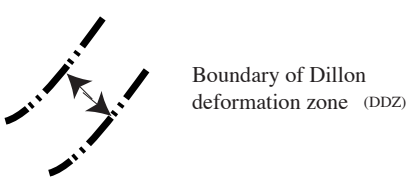

$2<\begin{aligned} & \text { Outline of }>10 \text { grade } \mathrm{X} \text { thickness } \\ & \text { contour }(\mathrm{Au})(\sim 0.3 \mathrm{oz} / \mathrm{t}) /\end{aligned}$

North Betze

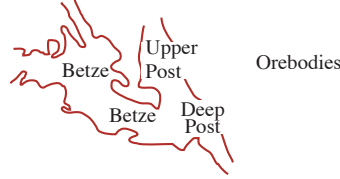

Figure 5. Schematic geology and outline of Betze and associated orebodies in the Goldstrike Mine area. Modified from Leonardson and Rahn (1996). Approximate longitude and latitude of center of map is $4058^{\prime} 30^{\prime \prime} \mathrm{N}, 11622^{\prime} 45^{\prime \prime} \mathrm{E}$. 
Sedimentary host rocks of the Betze orebody are lower-plate rocks of the lower Rodeo Creek unit, Popovich limestone, and upper Roberts Mountains Formation (Fig. 5). These units are composed of limestone, dolomite and siliciclastic material and also contain rare sedimentary breccias. These three units served, not only as host rocks for the Betze orebody, but also as conduits for migrating fluids and as host rocks for other orebodies along most of the north-central Carlin-trend (Fig. 3B).

The Rodeo Creek unit is composed of locally carbonaceous, bedded, siliciclastic mudstone (locally termed argillite), chert, and calcareous rocks. The hanging wall or northeastern part of the upper central Betze orebody is located along a deformed transitional contact between the Rodeo Creek unit and the underlying Popovich limestone. The transitional zone is composed of bedded siltstone, sandstone, chert, argillite, slaty mudstone, phyllonitic rock, fossiliferous massive muddy limestone, limy mudstone, and red knobby breccia bodies, across an interval of 20 to $40 \mathrm{~m}$. The transitional contact zone also contains intricate flow-like folding of white, gray and black, clay-rich siltstone (decalcified limestone) that locally is structurally interleaved with white to creamy, tan, and black, pyritic cataclastic pods composed of deformed massive to laminated argillite, and decalcified limestone and mudstone. Local dismembered phyllonitic bodies in the transitional sequence suggest that early deformation - possibly of Antler age $\left(\mathrm{D}_{1}\right.$, table 1$)$ - took place along this transitional contact zone, prior to $\mathrm{D}_{2}$ folding and was followed by $\mathrm{D}_{3}$ shearing and mineralization (Peters, 1997a).

The Popovich limestone is host rock for much of the Betze orebody and commonly is present as phacoidal-shaped, gray limestone and white to green-gray crystalline marble blocks that are surrounded by gray and black decalcified, clay-altered, deformed seams and breccia layers. Unaltered upper strata of the Popovich limestone are medium- to thin-bedded to massive, carbonaceous, micritic, and dark gray to black with local carbonate veinlets and diagenetic pyrite. The lower parts of the Popovich limestone and upper parts of the Roberts Mountains Formation contain horizons composed of both planar- and wispy-laminated, sandy, bioclastic dolomitic limestone. Local horizons are accompanied by soft-sediment deformation.

Sedimentary breccias in these host rocks are stratabound, lenticular facies composed of rip-up breccia, debris flow breccia, and fossil hash breccia (Griffin and others, 1993; Peters and others, 1997). Rip-up breccia bodies, along the transitional contact between the Rodeo Creek unit and the Popovich limestone, contain 0.5- to 2-cm-diameter laminated, angular clasts of siliciclastic argillite and shell fragments cemented by a fine-grained, sandy to silty matrix of similar material. Near the Betze orebody, these rip up breccia bodies are silicified. Debris flow breccia bodies and fossil hash breccia horizons are common in the middle and lower parts of the Popovich limestone and in the upper parts of the Roberts Mountains Formation over a 100- to 230-m-thick interval. Fossil hash beds are 0.5 to $3 \mathrm{~m}$ wide and contain whole or fragmented shells and fossil debris. These zones of sedimentary breccia constitute large parts of the Betze orebody and have been contact metamorphosed, decalcified, collapsed, and structurally deformed, which allowed them to provide ready passage to flow of hydrothermal fluids. 


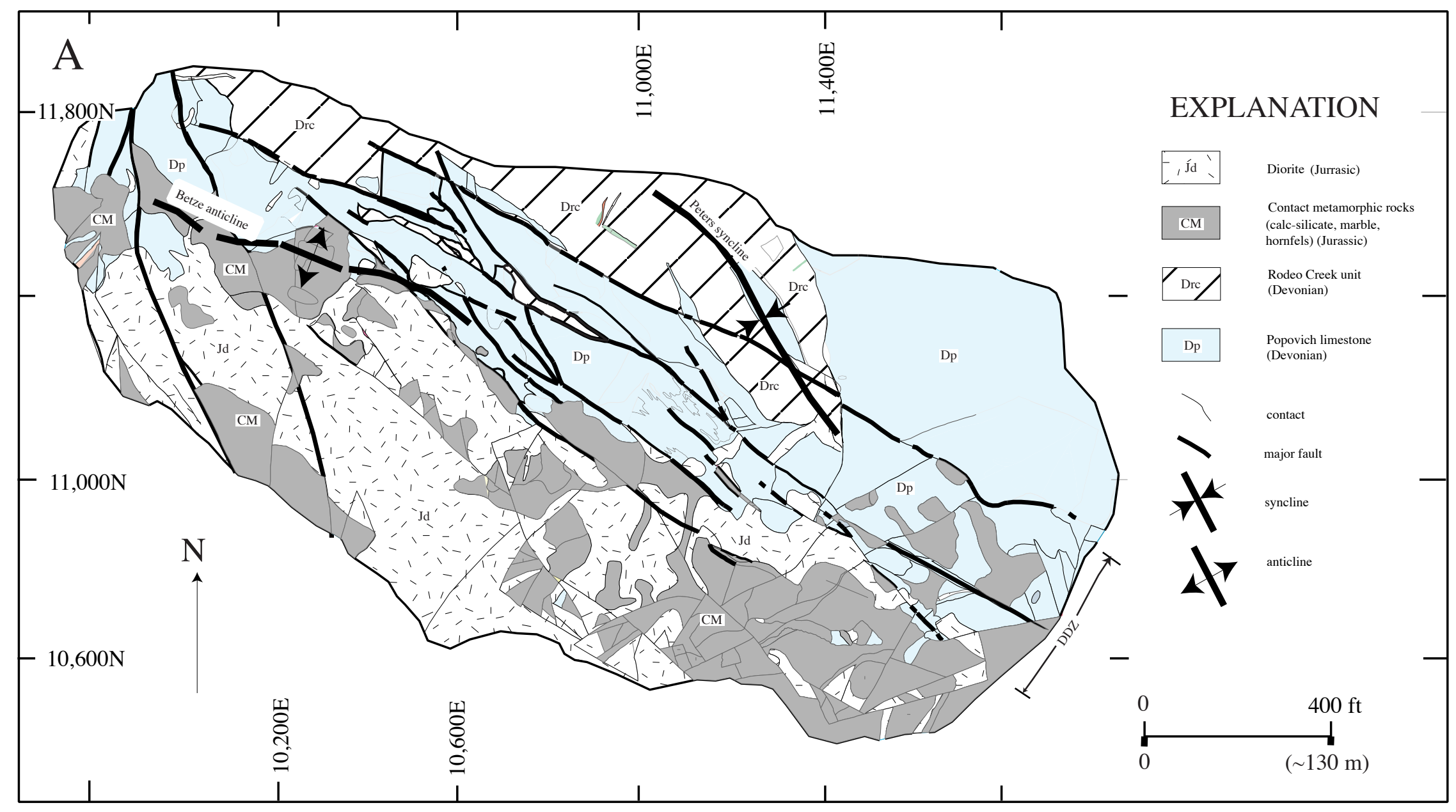




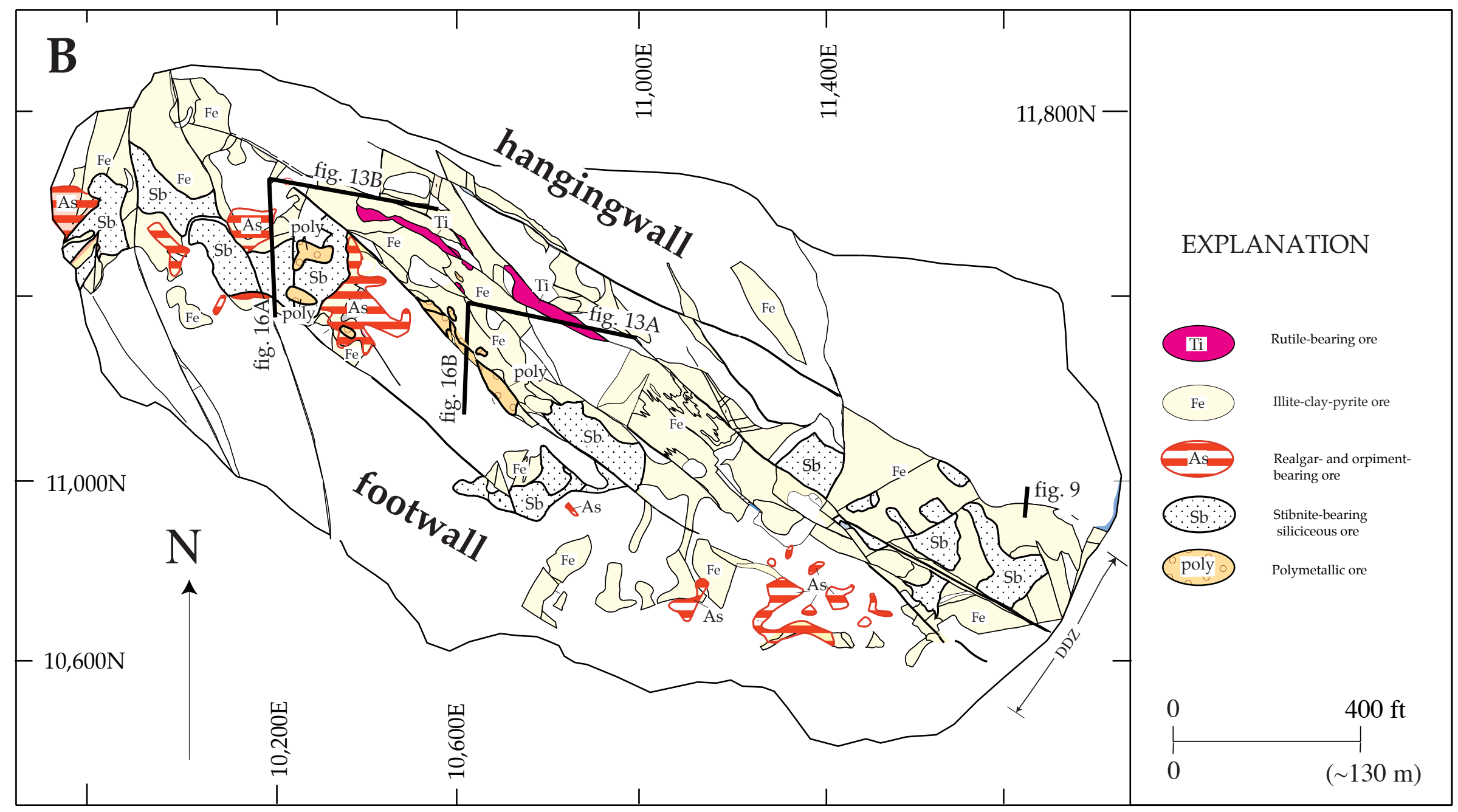

Figure 6. Geology of the 4,800 ft level Goldstrike Mine, showing distribution and zoning of oreshoots in the Betze orebody. (A) Distribution of main rock units, diorite, contact metamorphic rocks, Popovich limestone, and Rodeo Creek unit. (B) Location of oreshoots and alteration zones. Note also location of anticlines, DDZ, and bench sketch Figures. Approximate longitude and latitude of center of map is $4058^{\prime} 30^{\prime \prime} \mathrm{N}, 11622^{\prime} 45^{\prime \prime} \mathrm{E}$. 


\section{Igneous and Metamorphic Rocks}

The footwall or southwest part of the Betze orebody is hosted in the contact metamorphic zone of the Goldstrike stock (Figs. 5, 6A,B), which has intruded the Rodeo Creek unit, the Popovich limestone, the Roberts Mountains Formation, and rocks lower in the stratigraphic section. The stock is composed of homogenous, medium-grained and locally siliceous, biotite- and hornblende-bearing, gray diorite to tan quartz diorite and minor granodiorite with sills, dikes, and apophyses that extend into the hornfels and calc-silicate contact zone forming thin, irregular shapes (Fig. 6). Dikes and small intrusions of Late Jurassic lamprophyre and Eocene intermediate composition dikes also are present in the diorite and in the wall rocks (Leonardson and Rahn, 1996).

Contact metamorphism near the Goldstrike stock consists of pyroxene-biotite and silica hornfels and marble. These rocks locally are overprinted by diopside-grossular, diopside-grossular-vesuvianite, and tremolite-epidote-calcite $\mathrm{K}$-feldspar-diopside skarn (Walck, 1989), and by sericite alteration in the intrusive rocks. These contact metamorphic and metasomatic rocks are most common in a 230-m-wide zone adjacent to the main contact and near apophyses and epiphysis of the stock, along NNW-SSE-striking faults, as 300-mwide inliers in the diorite, and in structurally isolated blocks (Fig. 6A). The northeast contact of the Goldstrike stock parallels the WNW-ESE oriented trend of the Betze orebody. Textures and structural analysis of phacoids of diorite, calc-silicate rock, and marble indicate that the diorite-Popovich limestone contact has been deformed by $F_{3}$ (table 1) shear folding along the DDZ. Apophyses of diorite have been dismembered and isolated into phacoidal shapes along phyllonitic seams. Bodies of $15-$ to $70-\mathrm{m}$-thick metamorphosed and metasomatized rock provided large areas of mottled, brittle rock and protobreccia that subsequently were fractured and brecciated, and commonly were surrounded and isolated by illite-clay phyllonitic seams. Field relations strongly suggest that the main gold mineralization post-dates the Goldstrike stock (see also Arehart and others, 1993c; Leonardson and Rahn, 1996).

\section{Structure}

Most orebodies in the north-central part of the Carlin trend are associated with NNW-striking faults, such as the gouge-filled Post and JB faults, or with NNW-trending folds, such as the Post anticline and Peters syncline (Fig. 5) (see also, Resnell (1990). The most important NNW-SSE-striking fold in the Betze orebody is the pointed synclinal keel of the Peters syncline that contains rocks of the Rodeo Creek unit in contact with the more competent underlying rocks of the Popovich limestone (Fig. 5). The deformed transitional sequence in this keel between the two units acutely crosses and is deformed by shear folding in the WNW-ESE-striking upper central Betze orebody and these transitional sequence rocks in the orebody are further brecciated and show evidence of dissolution, shearing, decalcification, fluid flow, and folding. In lower parts of the orebody, the Roberts Mountains Formation is broadly folded below these units in the synclinal keel. 
The WNW-ESE orientation of the Betze orebody is anomalous when compared to the NNW-SSE orientation of the Carlin trend and its parallel faults and folds. These two orientations are separated by 40 to 50 degrees of strike (Fig. 4C). This consistent horizontalplunging WNW-ESE orientation of the Betze orebody has been attributed by several workers (Peters, 1996, 1997a; Leonardson and Rahn, 1996) to be related to the DDZ (Figs. 5, 6 and 7). Folds in the Goldstrike Mine all contain NNW-striking fold axes and axial planes outside the orebody, but contain WNW-ESE-striking orientations ( $\mathrm{F}_{3}$ folds?) inside the orebody (Fig. 4B). All WNW-ESE-striking fold axes in and proximal to the Betze orebody lie along a great circle that approximates a plane dipping $27^{\circ} \mathrm{NE}$ and striking 300û (Fig. 4B), parallel to the DDZ. The Betze anticline also lies in and is parallel to the DDZ (Fig. 5). Kinematic indicators of symmetry in the DDZ show both right lateral and left lateral movement, and displacement across the zone is equivocal, which suggests that deformation is restricted to a volume that closely approximates the Betze orebody and is consistent with non-steady ductile flow in shear zones as described by Dazhi and White (1995).

As interpreted by Peters (1996, 1997a) at the district scale in defining Domains I and II (Fig. 4A), the NNW-SSE-trending Post anticline and Peters syncline, are specific examples of originally NE-SW-trending regional-scale $\mathrm{F}_{2}$ folds, that have been refolded and rotated through shearing and refolding on WNW-ESE-striking $\mathrm{F}_{3}$ shear zones (in this case the DDZ) to their present NNW-ESE- and NW-SE-trending orientations. Some of this refolding can be seen in the change in strike of the axial planes of these folds as shown on Figure 5. Additional evidence of refolding can be seen as 100-m-wide internal fold closures on the western limb of the Post anticline. An alternative interpretation is that these NNWSSE-trending folds could be due to folding related to strike-slip faulting along the Post and JB fault systems. This last possibility is compatible with the conclusions of Evans and Theodore (1978) that these NNW-SSE-trending folds along the Carlin trend were generated by Jurassic tectonism.

Thick zones of tectonic breccia also serve as host rocks for much of the Betze orebody and are most common in the DDZ. These breccia zones are present in or related to shear zones, brittle faults, and associated folds and contain rock types with textures such as breccia, cataclasite, gouge, and phyllonite that have characteristics of fault zone rocks described by Sibson (1997), Ramsey (1980a) and Tanaka (1992). The main types include: (1) breccia formed along the Popovich limestone-Rodeo Creek unit contact; (2) cataclastic zones and fault gouge; and (3) breccia and phyllonite associated with strands of the DDZ. Mineralized, silicified, 20-m-thick, white to black, locally pyritic, cataclastic, breccia bodies consist of broken and crushed argillite, decalcified limestone, and mudstone. Breccia and phyllonite in the central parts of the DDZ consist of undeformed phacoidal clasts, slabs, and blocks present in sheared pelitic zones, which anastamose around them. Brecciation in the DDZ postdates the igneous apophyses and dikes of the Goldstrike stock and fragments of igneous rocks are present in many of the breccia bodies.

Strain in the DDZ was partitioned differently in each rock type. For example, pervasively sheared, $1-$ to 10-m-thick, phyllonitic strands are common locally, but elsewhere undeformed phacoidal clasts, slabs, and blocks lie in sheared, pelitic layers that anastamose around them. Breccia bodies are surrounded by seams of sheared, carbonaceous, illite-clay- 
rich phyllonite. This structural isolation of individual altered and mineralized cataclastic pods indicates multiple movements along individual fault planes. Deformation styles throughout the DDZ also indicate that products of processes of dissolution, transport, fluid flow, plucking, decalcification, and high strain are spatially coincident with gold and its associated geochemical elements and further suggests that the hydrothermal and deformational events may have been linked in time and in space, such that mineralization and deformation were, at least in part, synchronous.

\section{Mineralization}

The Betze orebody is surrounded by as many as twenty smaller contiguous and noncontiguous orebodies in an approximate 3,000 by $1,200 \mathrm{~m}$ area over a $700 \mathrm{~m}$ vertical extent. Mine-scale mapping and drilling has defined an ore outline as a $0.035 \mathrm{oz} / \mathrm{t}(\sim 1.0 \mathrm{~g} / \mathrm{t}) \mathrm{Au}$ contour line (Fig. 5) that has an average thickness of $170 \mathrm{~m}$, an average width of $200 \mathrm{~m}$, and a strike length of over $1.5 \mathrm{~km}$ (Bettles and Lauha, 1991; Leonardson and Rahn, 1996). Patterns of alteration zoning in and surrounding the Betze orebody define a large, porous, dilated zone where fluid flow was high. Several different ore types and ore grades are distributed in discrete oreshoots. A central 0.3 by $2 \mathrm{~km}$ core of high-grade gold-associated illite-clay and silica alteration in and adjacent to the high-grade oreshoots is surrounded by 500-m-thick lower-grade zone of decalcification and weak illite-clay. Contours of gold and sulfide sulfur content in the orebody (Figs. 7A, and B) indicate that most oreshoots are concentrated along the WNW-ESE-trending diorite- Popovich limestone contact, the NNWSSE-striking Popovich limestone-Rodeo Creek unit contact in the keel of the Betze syncline, individual strands of the WNW-ESE-striking DDZ, and along ENE-WSW-striking fault zones (not shown on Fig. 5) that cross cut the DDZ.

Oreshoots contain cataclastic mixtures of crushed, altered, and brecciated wall rock, gouge, and phyllonite that are spatially related to host rock types and to faults and folds. The oreshoots cluster in a zonal pattern in plan from the hanging wall to the footwall of the orebody and in section with pyrite- and arsenic-rich ores on the top or outside of the orebody and quartz (antimony)-rich ores in the bottom and center parts. Analysis of mesoscopic distribution and crosscutting relations between these oreshoots indicates an orebody-scale paragenesis that can be used with other microscopic and geochemical tools and methods to interpret the timing and genesis of the orebody. Because much of the Betze orebody is structurally controlled, the relation of ore deposition to the host breccia, phyllonite and folds determines processes of ore genesis in terms of the regional tectono- paleo-thermal history.

\section{Hydrothermal Alteration}

Alteration types associated with gold mineralized rocks in the Betze orebody include: carbonation (carbon introduction), decarbonatization (decalcification), argillization (illiteclay), and silicification, similar to alteration types in other Carlin-type ore deposits described by Radtke (1985), Bakken and Einaudi (1986), Kuehn and Rose (1992), and Arehart (1996). 


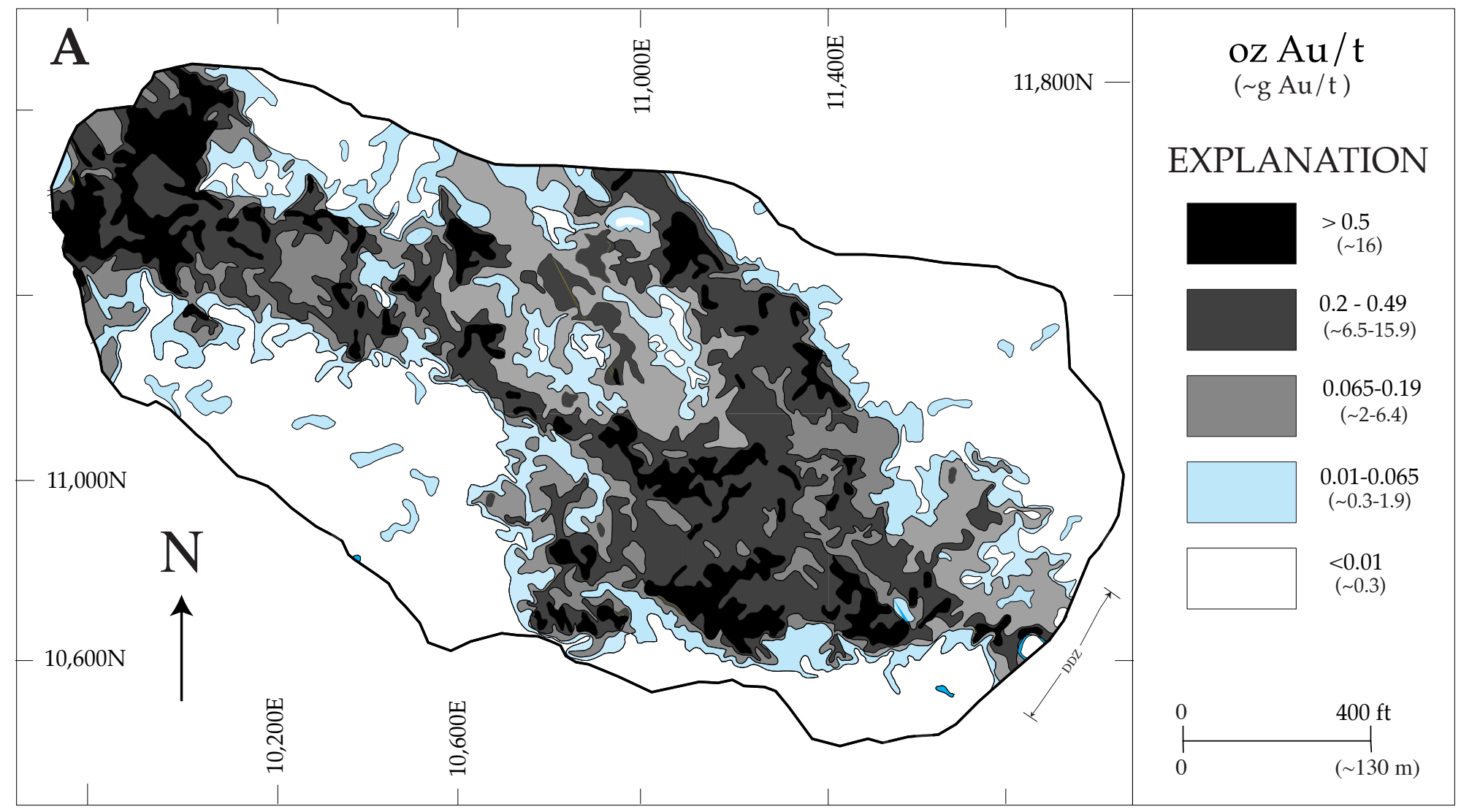




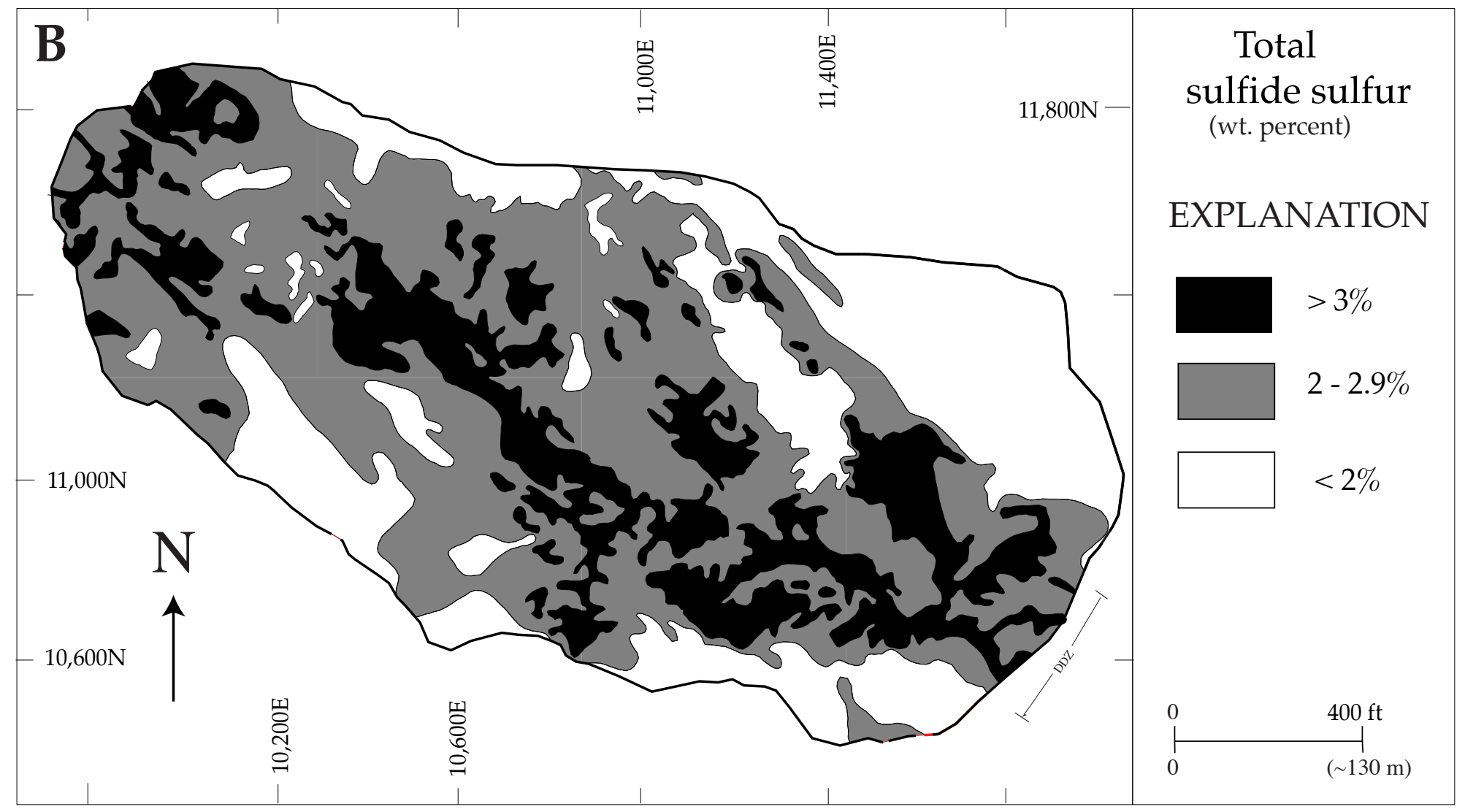




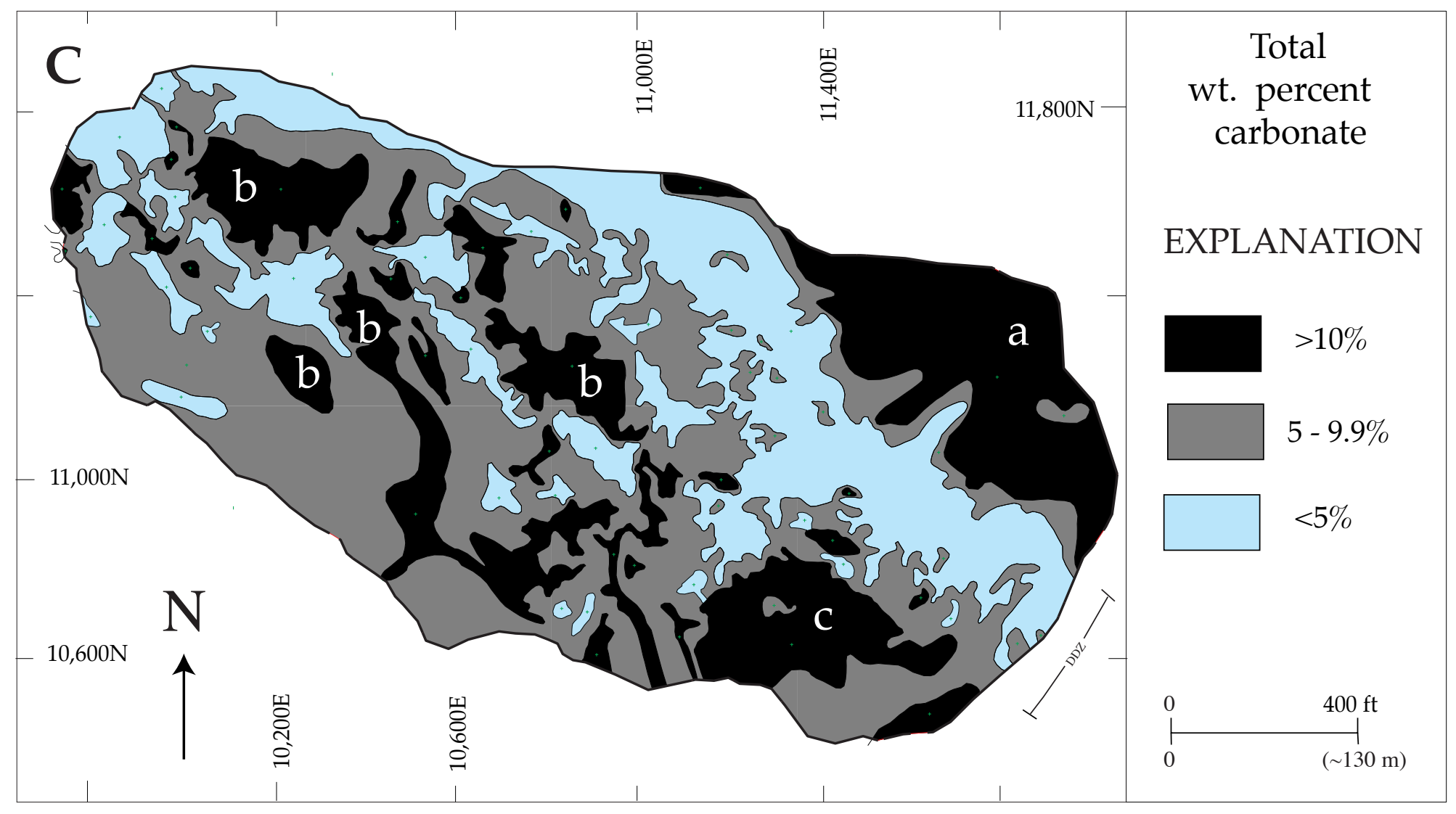

Figure 7. Contour maps of blasthole assays for (A) gold, oz/t, (B) total wt. percent sulfur as sulfide, and (C) total wt. percent carbonate, Betze orebody, Goldstrike Mine. Areas noted in text as a (unaltered Popovich limestone; areas b (calc-silicate phacoids); and c (areas of realgar and orpiment with calcite blebs and veining. See Figures 5 and 6 for geology. Blast holes are $20 \mathrm{ft}(6.5 \mathrm{~m})$ deep and spaced on a $20 \mathrm{ft}(6.5 \mathrm{~m})$ grid. Approximate longitude and latitude of center of map is $4058^{\prime} 30^{\prime \prime} \mathrm{N}, 11622^{\prime} 45^{\prime \prime} \mathrm{E}$ 


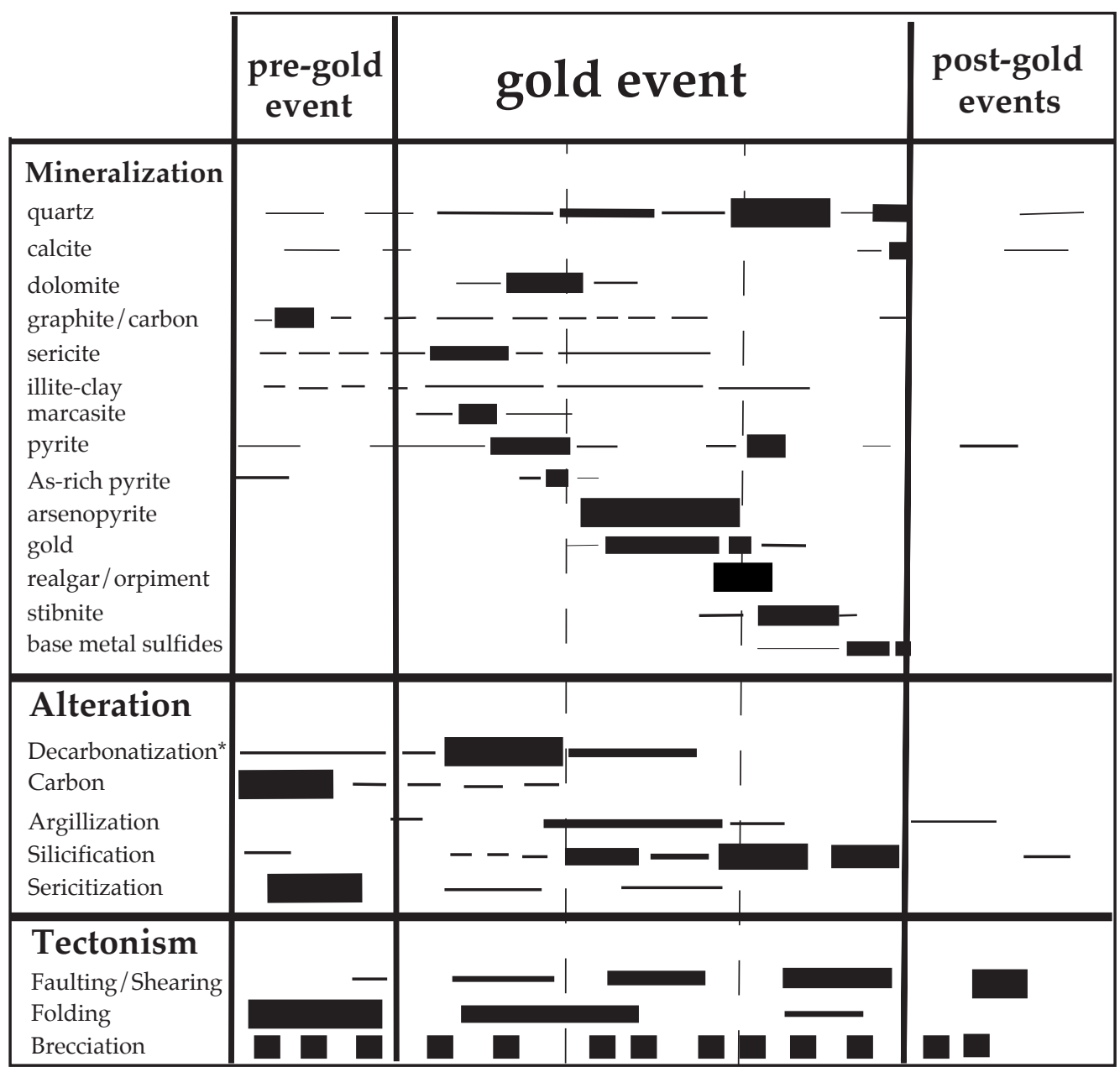

*includes decacification

Figure 8. Summary of paragenesis of minerals and events in the Betze orebody. Hydrothermal mineral associations overlap from one stage to another, such that different stages of mineralization formed both sequentially and simultaneously, depending on fluid flow pathways and location in the ore body. Adapted from Ferdock and others (1997) where additional minerals, such as barite, are discussed. 


\section{NORTH}

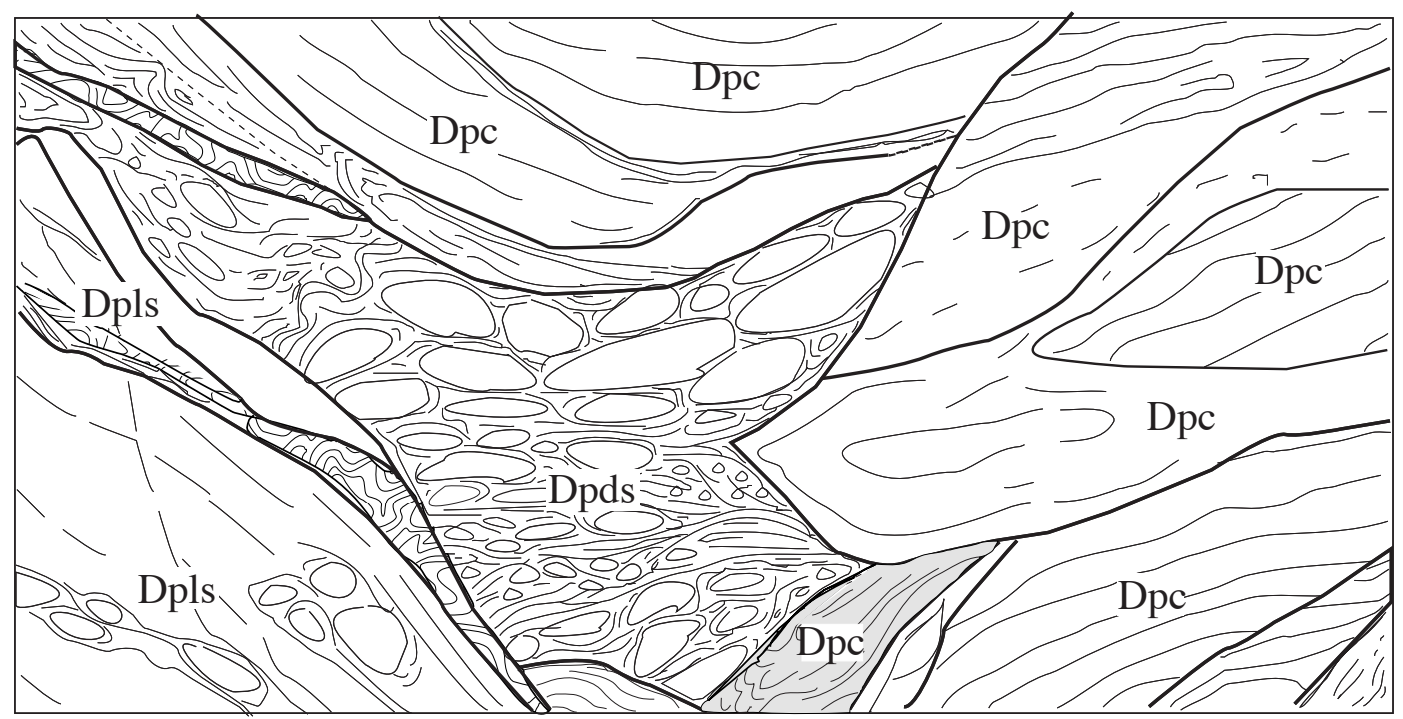

\section{EXPLANATION}

Dpls Popovich limestone (Devonian) (unaltered)

Popovich limestone (Devonian) (clay-altered and mineralized)

Popovich limestone (Devonian) (mixture of unaltered phacoids and decalcified, tectonized clay seams showing dissolution textures)

$0 \quad 5 \quad 10 \mathrm{~m}$

Figure 9. Example of mesoscopic dissolution textures in a multiple bench sketch on the 4,800 level (bottom of sketch), looking southeast (see Fig. 6B for location). Form lines show deformation and dissolution (decarbonatization and decalcification) in the Popovich limestone.

Southern part of sketch is gold-bearing. The north and central parts of the sketch are unmineralized. The phacoidal-shaped textures in the center part are interpreted as a dissolution front adjacent to the orebody. 
Pre-gold alteration assemblages include syngenetic or diagenetic minerals in Paleozoic sedimentary rocks, as well as contact metamorphic and metasomatic mineral associated spatially with the contact of the Goldstrike diorite. Post-gold alteration effects are related to supergene processes and locally to Miocene hot-spring related events associated with Basin and Range development (Fig. 8). The high-grade, upper $30 \mathrm{~m}$ of the Betze orebody contains an alteration assemblage of illite-clay minerals, whereas the lower parts of the orebody generally are silicified. The outer alteration zone, outward from the $0.035 \mathrm{oz} / \mathrm{t}$ Au contour (Fig. 5), has an irregular shape and is composed of non-contiguous, black, carbonaceous bodies of weak illite-clay alteration and silicification. The difference between alteration in the Betze orebody system and those in other Carlin-type deposits is (1) the large area of alteration and (2) the superposition of the alteration on zones of contact metamorphism and metasomatism, as well as intense structural deformation at Betze.

Carbonation as pre-gold carbon (Fig. 8) is present in large masses of black, sooty sedimentary rocks that surround and lie in the orebody, and is similar to carbon associated with most Carlin-type deposits (see Radtke and Scheiner, 1970a, b; Kuehn, 1989). Carbon content in the main orebody is generally less than $1 \mathrm{wt}$. percent, whereas areas surrounding the northern parts of the orebody contain carbon contents in excess of $10 \mathrm{wt}$. percent. This distribution of carbon away from the main orebody has been attributed by Leonardson and Rahn (1996) to be caused by the mobilization of carbon outward from the Goldstrike stock during intrusion, and the tendency for gold to be precipitated proximal to the Goldstrike stock contact inside this mobilized carbon front. The carbon usually takes the form of $2-$ to $15-\mu \mathrm{m}$-size platy crystals and aggregates away from ore and is present as angular grains of less well-crystallized graphite or carbon in the ore. Carbon may also have been remobilized during gold deposition (Ferdock and others, 1997), as suggested by bitumen-calcite veinlets. Carbon is present in illite-clay altered sedimentary horizons, in phyllonitic sheared seams in the hanging wall of the upper central orebody, along high-angle fault zones above ore, and in beds of the Rodeo Creek unit and Popovich limestone-particularly the Post anticlineabove the orebody (Peters, 1997a). Local areas of carbon inside the orebody may have been important in the deformation history of the Betze deposit, because they represent areas of low shear strength and were therefore commonly areas of high strain.

Decarbonatization, and decalcification, have affected large parts of the Popovich limestone and to a lesser extent the Rodeo Creek unit and Roberts Mountains Formation, along a 100-m-wide zone in the central part of the orebody (Fig. 7C). Decarbonatization has removed carbonate minerals and much of the $\mathrm{Fe}, \mathrm{Mg}$, and $\mathrm{Ca}$. Decalcification refers to the removal of calcite and is the general term used in field mapping. Leonardson and Rahn (1996) indicate that decalcification expanded vertically along fractures into tabular, beddingparallel layers, and therefore collapse breccia bodies are most common as stratabound zones in the central parts of the orebody. During decarbonatization and decalcification the carbonate content in limestone decreased from 30 to $40 \mathrm{wt}$. percent to as much as less than 1 wt. percent. Carbonate content in the orebody is spatially variable, but a relatively uniform central zone of generally less than $10 \mathrm{wt}$. percent carbonate lies along the central part of the DDZ (Fig. 7C). Magnesium content in dolomitic rocks and lamprophyre dikes follows a similar pattern. Several discrete areas in this WNW-trending central low carbonate zone 
(Fig. 7C) have higher carbonate contents: (1) northeastern areas coincide with dark gray, unaltered, relatively undeformed Popovich limestone (area a, Fig. 7C); (2) southwestern and northwestern areas coincide with unmineralized and unaltered marble along the dioritePopovich limestone contact (areas marked b, Fig. 7C); and (3) the southeastern area represents seams of high-grade realgar-orpiment ore with calcite veining surrounding barren marble phacoids (area c, Fig. 7C).

Decarbonatized collapse breccias contain 30 to 50 vol. percent, centimeter-size, anhedral clasts of multicolored rock fragments, contained in a 50 to 70 vol. percent finegrained matrix of small, millimeter-scale rock fragments and illite-clay minerals (Fig. 9). Contact metamorphism, illite-clay alteration, silicification, and deformation have overprinted early-formed collapse breccias, which may themselves have been superimposed over sedimentary breccia (Peters and others, 1997). Decarbonatization of the limestone and marble resulted in increased permeability that provided conduits for gold-bearing fluids. Volume loss and collapse most likely accompanied phyllonite development and was associated closely in time with a hydrothermal event. Many collapse- and tectonic-related megabreccias have oriented fabrics defined by illite-clay-rich brecciated fragments and phyllonite seams that surround phacoidal-shaped blocks of limestone or marble (areas A, B and $\mathrm{C}$ on Fig. $7 \mathrm{C}$ ), indicating that fluid pathways were along these phyllonitic zones and that much of the dissolution and collapse was synchronous with strain (Fig. 9).

Argillization as illite-clay alteration is pervasive forming soft, elongate, pervasively altered masses of rock in the upper $30 \mathrm{~m}$ of the Betze orebody. Illite-clay alteration also is present as widespread mesoscopic stratabound layers and microscopic inter-layers with quartz, especially in the lower parts of the orebody. Illite-clay alteration commonly is associated with gold in the north-central Carlin trend (see Drews-Armitage and others, 1996), where illite is the dominant clay mineral phase, although, dickite, smectite, and kaolinite locally are present separately in the rock or are interlayered in the illite crystals. Diorite is transformed to soft, white- to green- to tan-colored rock with relict igneous textures. Beds of dark gray Popovich limestone are altered to soft, creamy white, gray and black layers rich in clay, sulfide and carbon. Altered parts of the Popovich limestone commonly are sheared or folded and these softer areas surround unaltered, hard, phacoidal or round 1- to 10-m-size blocks of undeformed massive limestone, marble, or calc-silicate rock. Crystallinity of illite in the Betze orebody is similar in phyllonite $\left(0.36^{\circ}\right.$ to $\left.0.54^{\circ} 2 \theta\right)$, in clay fault gouge $\left(0.38^{\circ}\right.$ to $\left.0.41^{\circ} 2 \theta\right)$, in decalcified rock $\left(0.38^{\circ}\right.$ to $\left.0.57^{\circ} 2 \theta\right)$ and in illite-clay altered silty limestone $\left(0.39^{\circ}\right.$ to $\left.0.53^{\circ} 2 \theta\right)$. The range of $0.2 \Delta 2^{\circ} \theta$ in these rocks is close the minimum value $\left(0.1^{\circ}\right.$ $2 \theta$ ) for the degree of confidence of illite crystallinity measurements discussed by Robinson and others (1990). This suggests that clay minerals in these rocks at some time reached similar temperatures and is compatible with synchronous deformation and hydrothermal alteration. Crystallinities of illite in altered diorite and calc-silicate rock $\left(0.73^{\circ}\right.$ to $\left.1.05^{\circ} 2 \theta\right)$, suggest that either lower temperatures were reached in these rocks or may indicate addition clay minerals, such as smectite, that are interlayered with the illite.

Silicification is present in isolated breccia bodies-and to a lesser extent in unbrecciated rock - in the hanging wall and footwall parts of the upper orebody and 
increases in the lower parts of the orebody (Fig. $11 \mathrm{~B}$ ). Silicification mainly consists of cryptocrystalline and microcrystalline quartz between and replacing breccia clasts, but also is present as $1-$ to $2-\mathrm{mm}$-thick veinlets that cut breccia clasts. Multiple stages of silicification are common in local areas; for example, fine-grained quartz replaces breccia clasts and coarse-grained quartz replaces or forms the matrix of the breccia. Leonardson and Rahn (1996) record at least five stages of silicification, some of which are similar to the quartz veinlet stages recorded by Bakken and Einaudi (1986) and Kuehn and Rose (1995) in the Carlin deposit. Quartz veinlets containing As-rich, gold-stage pyrite commonly parallel phyllonitic foliation and are broken and fractured, indicating shear zone movement during or after silica emplacement. Silicified breccia bodies and cataclastic zones commonly are isolated structurally, surrounded by phyllonitic illite-clay seams or by fault gouge, also indicating post-silicification shear zone movement. In some siliceous breccias, parts of the matrix are not filled or replaced by quartz but consist of angular voids, similar to crackle breccia. Silicified areas contain both micro- and mesoscopic-scale mixed zones of illite-clay that alternate with bands of silica along bedding planes or along deformation fabric layers. Silicification of diorite, hornfels and calc-silicate rock is rare; however, residual, pre-gold, microcrystalline silica in subsequently altered contact metamorphic and metasomatic rocks forms the protolith for most breccia fragments in the silicified oreshoots.

\section{Paragenesis}

Mineral deposition stages in the Betze orebody are designated as pre-gold, syn-gold and post-gold stages on the basis of field mapping and crosscutting relations determined microscopically (Fig. 8). The syn-gold stage also has been divided into three substages by Ferdock and others (1997). Pre-ore stages are: (1) Paleozoic detrital or diagenetic events; (2) contact metamorphic, metasomatic or hydrothermal base metal-dominated mineral deposition associated with the Late Jurassic Goldstrike stock; and (3) early hydrocarbon mobilization. Post-gold ore mineral development consisted of minor hypogene and supergene events (Fig. 8).

Gold-stage ore deposition in the Betze orebody started with disseminated pyrite, followed by As-rich pyrite (Fig. 10A) with micron-scale gold deposited as a separate phase or contained in As-rich rims grown on early pyrites, similar to those described by Wells and Mullen (1973), Arehart and others (1993a,b), Fleet and Hamid (1997), and Bakken and others (1989) in other Carlin-type deposits. Temporal relations between mineral phases is indicated by most workers to start with the deposition of pyrite with gold-rich, As-rich rims, followed by ore rich in orpiment-realgar, barite, stibnite, and mercury. This paragenetic sequence also is the same as that produced by geochemical modeling of typical Carlin-type systems due to fluid-rock interaction and to cooling of the hydrothermal system from $210^{\circ}$ $200^{\circ} \mathrm{C}$ to $180-150 \mathrm{C}$, at moderate salinity ( $<10$ wt. percent $\mathrm{NaCl}$ equivalent) (Hofstra and others, 1991; Woitsekhowskaya and Peters, 1998).

Geochemical modeling also indicates that the hydrothermal fluid contained gold complexed as $\mathrm{Au}(\mathrm{HS})_{2}{ }^{-}$, whereas the dominant arsenic complex was $\mathrm{H}_{3} \mathrm{AsO}_{3}$, and antimony 

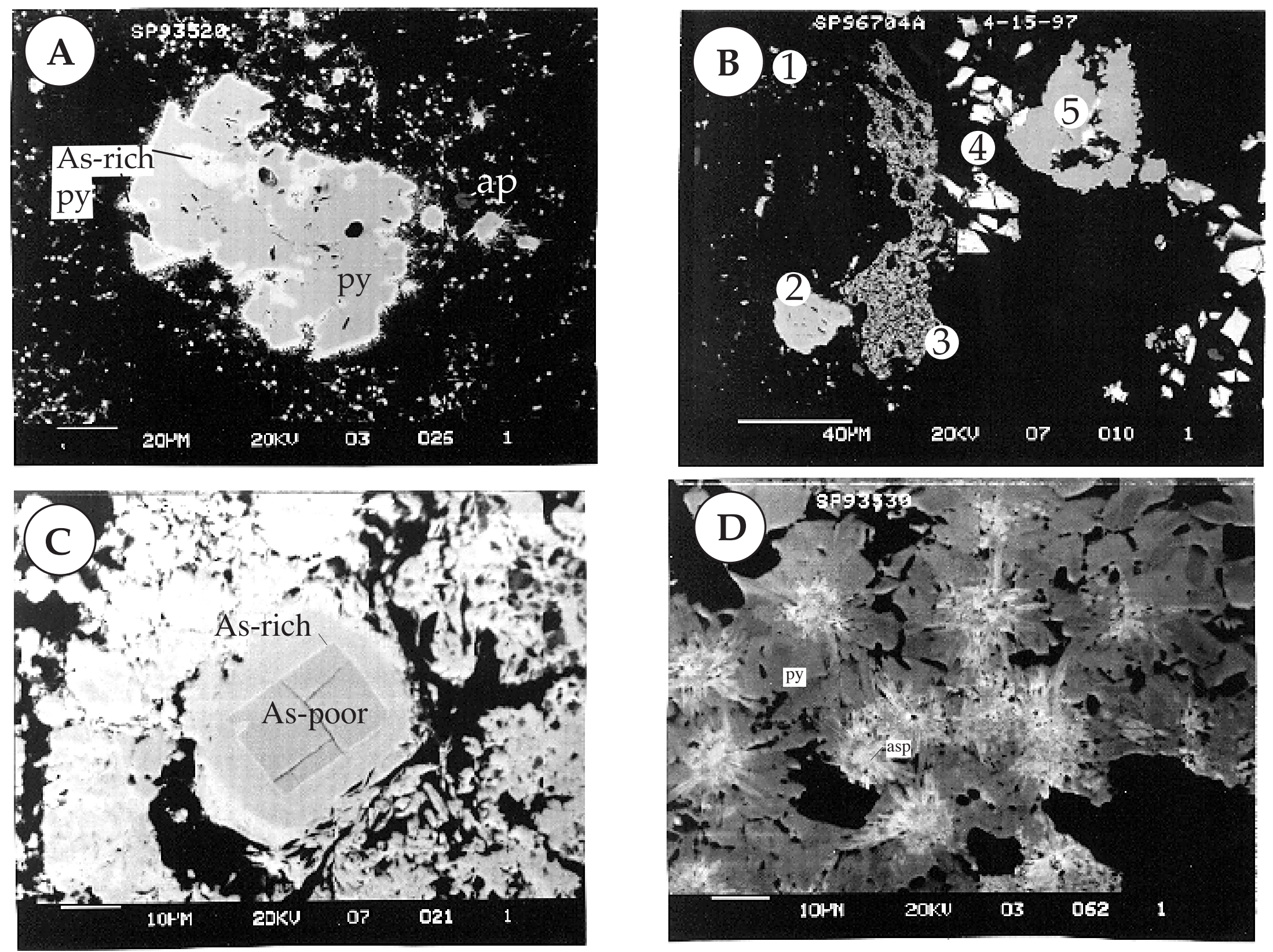

Figure 10. Photomicrographs of different textures and morphologies of pyrite in the Betze orebody. (A) As-rich rims on subhedral pyrite with hair-like growths in matte of illite-clay, quartz and local apatite. (B) Five separate pyrite textures in 200-mm-wide field, 1 - disseminated, 2 - brecciated, round, 3 - spongy, 4 - brecciated, angular, and 5 - zoned with As-rich rims. (C) Oscillatory zoned pyrite (light areas As-rich; dark areas As-poor) around fractured euhedral pyrite. (D) Rare reverse-zoned pyrite with arsenopyrite cores (bright dots), As-rich radiating central parts, and As-poor rims. These reverse-zoned pyrites are in altered contact metamorphosed rocks. 


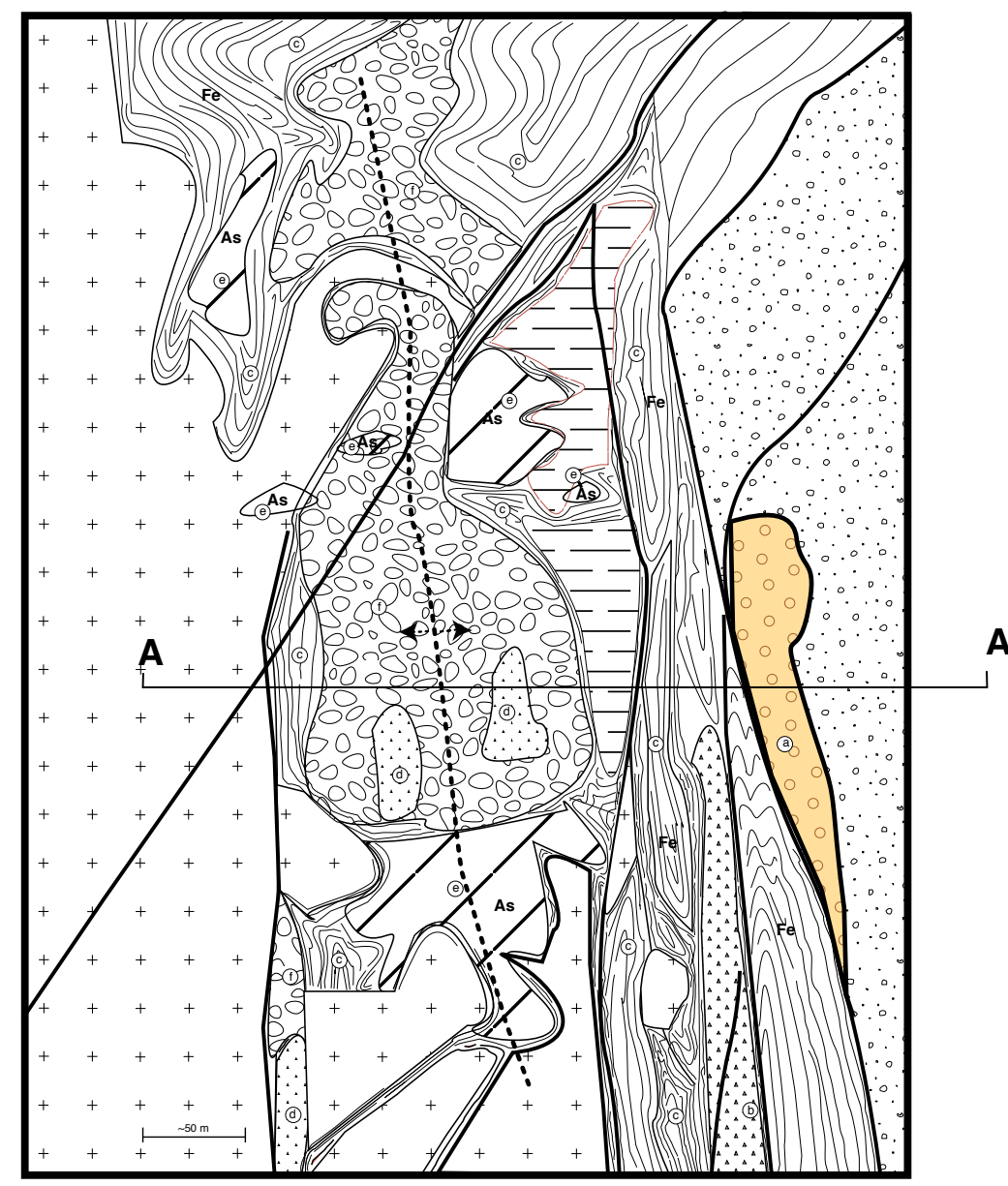

EXPLANATION

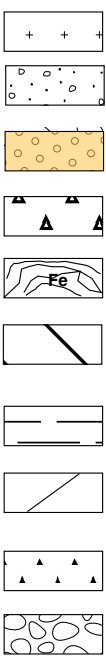

(C)

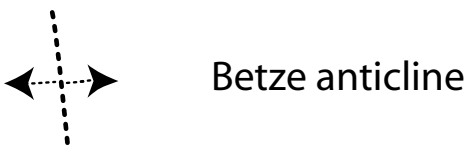

Diorite and marble and marble

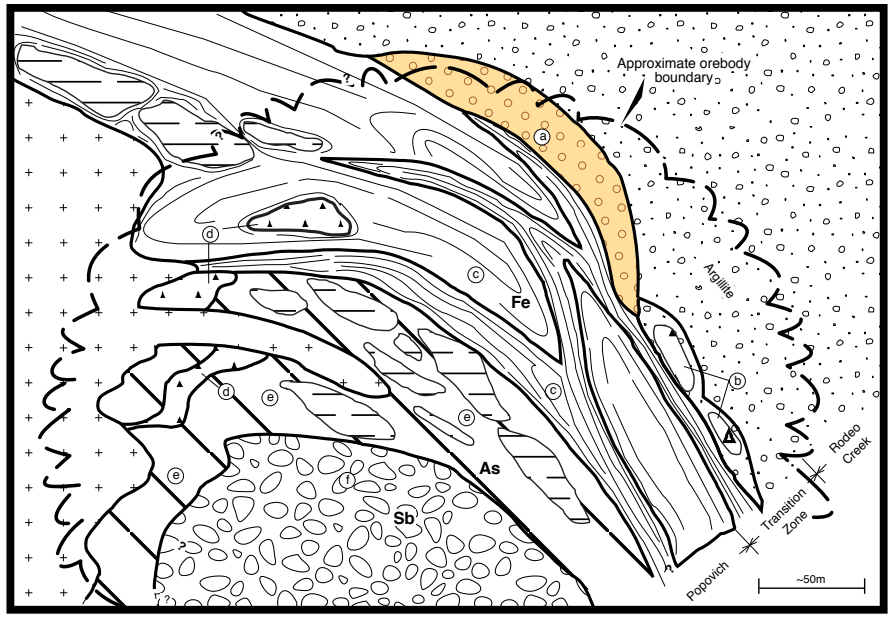

Rodeo Creek unit, argillite

Cataclastic breccia

Siliceous breccia pods

Carbonaceous tectonite

Decalcified limestone

Remnant limestone

Arsenic-rich breccia

Polymetallic breccia

Siliceous breccia

Ore type of Peters (1996)

A

$\mathbf{A}^{\prime}$

Figure 11. Generalized diagrammatic plan and section of zoned oreshoots in the upper central Betze orebody (A) Idealized plan view of components of the Betze orebody hosted in Popovich limestone between diorite (left) and Rodeo Creek unit (right). (B) Section A-A'. Idealized projected sketch through the upper central Betze orebody, looking WNW (approximate match to A-A' on Figure 11A). General zoning in the orebody is illite-clay-pyrite, Fe-rich ores on the top, realgar- and orpiment-bearing As-rich ores in the central parts, and stibnite-bearing (Sb-rich) siliceous ores at the bottom. (adapted from Peters, 1996, 1997). 
was complexed as $\mathrm{Sb}(\mathrm{OH})_{3}$ (Woitsekhowskaya and Peters, 1998). Gold, arsenic, antimony and other components in ore were transported by these chemical complexes to the depositional sites from outside the orebody at initial total pressures of approximately 1,200 bars (Lamb and Cline, 1997). The major features of the alteration zonation pattern observed in the orebody resulted from the reaction of the ore fluid with host rocks as the system cooled and pressure decreased. During dissolution-precipitation reactions, including carbonate dissolution, both silica-leaching and silica-fixation, and sulfide mineral precipitation controlled mass transfer in the Betze orebody. Mass transfer calculations (Woitsekhowskaya and Peters, 1998) indicate that gold precipitation was associated with sulfidation of reactive iron in the system. This sulfidation further created higher hydrogen and lower sulfide sulfur activities in the system, which then destabilized the $\mathrm{H}_{3} \mathrm{AsO}_{3}$ and $\mathrm{Au}(\mathrm{HS})_{2}{ }^{-}$complexes, and caused gold precipitation in association with As-rich pyrite. This model is similar to precipitation mechanisms suggested for Carlin-type systems in general by Rytuba (1985), Hofstra and others (1991), and Stenger and others (1998) and confirms that sulfidation of host rock iron, during reaction of the ore fluid with host rock, was the primary gold precipitation mechanism.

Combinations of different minerals, such as As-pyrite, orpiment and realgar, stibnite, quartz calcite and other minerals help distinguish different types of ore on a mesoscopic scale, although microscopic assemblages are not always definitive. For example, at least five types of pyrite (Fig. 10B) in the Betze orebody, including oscillatory zoned (Fig. 10C) and rare reversibly zoned pyrite (Fig. 10D), suggest local complex paragenesis. The As-rich pyrite was followed and over-printed by realgar, orpiment and calcite, and coeval-but spatially separate - quartz, barite, stibnite, and sphalerite (Fig. 8). These gold-stage assemblages have similar form, shape and style in the orebody, but are present in separate areas along the DDZ, where they are isolated from each other in separate masses by fault gouge and phyllonitic seams. Structural and geometric similarity of each ore type suggests that they formed in a similar structural environment rather than from multiple mineralizing systems or events punctuated by time intervals.

The evolving stages of hydrothermal mineral development associated with gold ore deposition overlapped due to cycling of the circulating hydrothermal fluid, such that different mineral assemblages formed both sequentially and simultaneously, depending on fluid-flow pathways through the orebody (Ferdock and others, 1997). The gold mineralizing events evolved from initial preparation of an environment conducive to early gold deposition to a dominant gold-depositing event, which was followed by late deposition of calcite and quartz (Fig. 8). Most hydrothermal gangue minerals were formed late and represent concentration and deposition of the elements remaining in solution, principally $\mathrm{Sb}, \mathrm{As}, \mathrm{Ba}, \mathrm{Fe}, \mathrm{S}$ and lesser amounts of $\mathrm{Zn}, \mathrm{W}$, In, Co, Cd, Se, Cs, Tl, and Hg. Some sulfate minerals (barite and gypsum) and some carbonate minerals (calcite, dolomite, and siderite) precipitated late.

\section{Zoning and Control of Oreshoots}

Distribution of different ore mineral associations and alteration types in the Betze

orebody is dependent on structural setting, host rock, and location in the orebody. On the 
basis of morphology, mineralogy, and geologic setting, several spatially distinct styles of ore are recognized and cluster into elongate oreshoots, separated from one another by waste or low-grade rocks. These oreshoots constitute three-dimensional geochemical, mineralogical, geological, and metallurgical zoning in the orebody. Separate ore control mechanisms of individual oreshoots correlate with individual strands of the DDZ and with local shear folding in the Betze anticline. Local control of the location and shape of the oreshoots also is due to features in the keel of the Peters syncline, petrology of the sedimentary rocks, and geometry and thickness of the diorite contact (Figs. 6A,B).

Classification and discrimination of different oreshoots is made on the basis of previous studies of the different ore types and host rock types in the orebody. Six distinct ore types were recognized in the Betze orebody by Peters $(1996,1997 a)$ and by Leonardson and Rahn (1996). These ore types and their related rock types roughly correlate with oreshoot types and are portrayed on Figures 11 and 12. Breccia is the most common host rock type in the oreshoots and breccia types were differentiated by Peters and others (1997) on the basis of geologic setting, mineralogy, geochemistry, and morphology.

In addition to distinct petrologic features related to breccia type, oreshoots also are characterized by variable geometry, mineralogy, geochemistry, structural style, and location in the orebody. None of these features are distinct for all oreshoots. Oreshoots consist of five main types: (1) rutile-bearing siliceous oreshoots; (2) illite-clay-pyrite oreshoots; (3) realgar- and orpiment-bearing oreshoots; (4) stibnite-bearing siliceous oreshoots; and (5) polymetallic oreshoots (Figs. 11 and 12). Characteristics of these oreshoot types are given on table 2. Geochemical analyses of representative samples from each oreshoot type is given in table 3. The following summary of the characteristics of the oreshoots is given from the hanging wall to the footwall of the orebody, or from the northeast to southwest parts (see Fig. $6 \mathrm{~B}$ ) and roughly coincides with the older to younger paragenetic development of the orebody. About three dozen distinct oreshoots are present on the 4,800-foot elevation in the upper central Betze orebody and at least 60 percent of the orebody can be viewed as occurring in oreshoots.

\section{Rutile-Bearing Siliceous Oreshoots}

Rutile-bearing siliceous oreshoots (hanging wall siliceous breccia bodies of Peters, 1996, 1997a) are present along a 300-m-long zone at the transitional contact between the Rodeo Creek unit and Popovich limestone. They are characterized on a mesoscopic scale as 6- to 40-m-long, 2- to 25-m-wide, knobby, red to dark gray, shallow-dipping, lenticular pods (Figs. 5, 6B, 11; table 2). These oreshoots are further characterized on a microscopic scale by mm-size or smaller mottled-textured, pisolitic, millimeter- to micron-scale grain aggregate intergrowths of different combinations of ilmenite, titanite, magnetite, pyrite, rutile, sphalerite, and pisolitic apatite (Fig. 14). These oreshoots typically are anomalous in $\mathrm{Zn}, \mathrm{Ni}, \mathrm{V}, \mathrm{P}$, and $\mathrm{Tl}$ (table 3 ) and have gold grades between 0.5 and $2.0 \mathrm{oz} \mathrm{Au} / \mathrm{t}$ ( 15.5 to 64 $\mathrm{g} \mathrm{Au} / \mathrm{t})$. Detrital minerals in the transitional sequence of rocks between the Rodeo Creek unit and Popovich limestone account for local minerals high in Ti, U, and REE. Some zircon grains also are present intergrown with REE minerals, or with $\mathrm{Ti}$ minerals in 


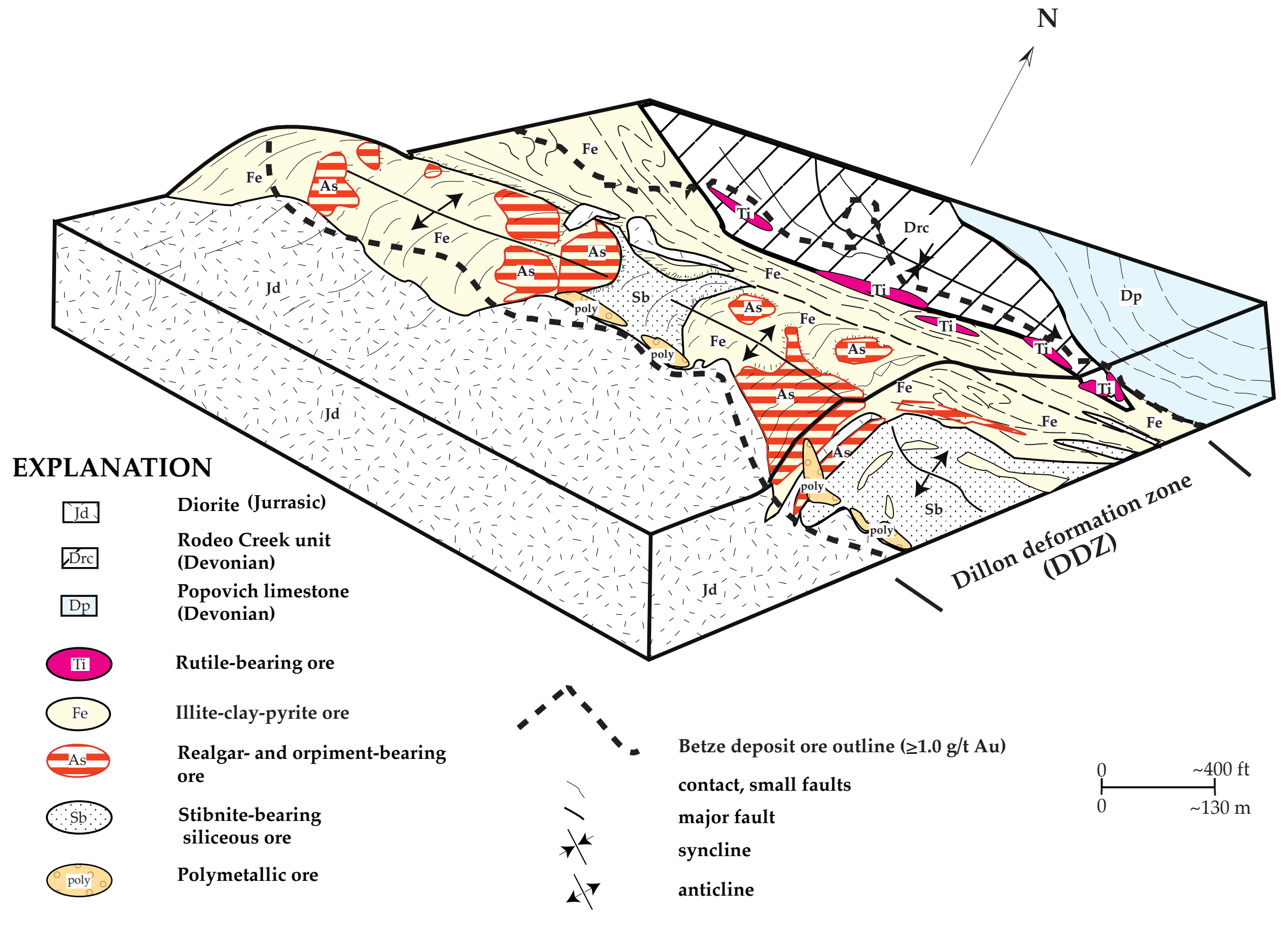

Figure 12. Diagrammatic block diagram of the Betze orebody at about the 4,600 to 5,000 ft. Elevation showing the spatial distribution and zoning of types of oreshoots and their relation to the DDZ, Betze anticline and Peters syncline. Illite-clay-pyrite ores also have internal pod-like geometries, but are not shown. Note that contact metamorphic and metasomatic rocks are not shown. 

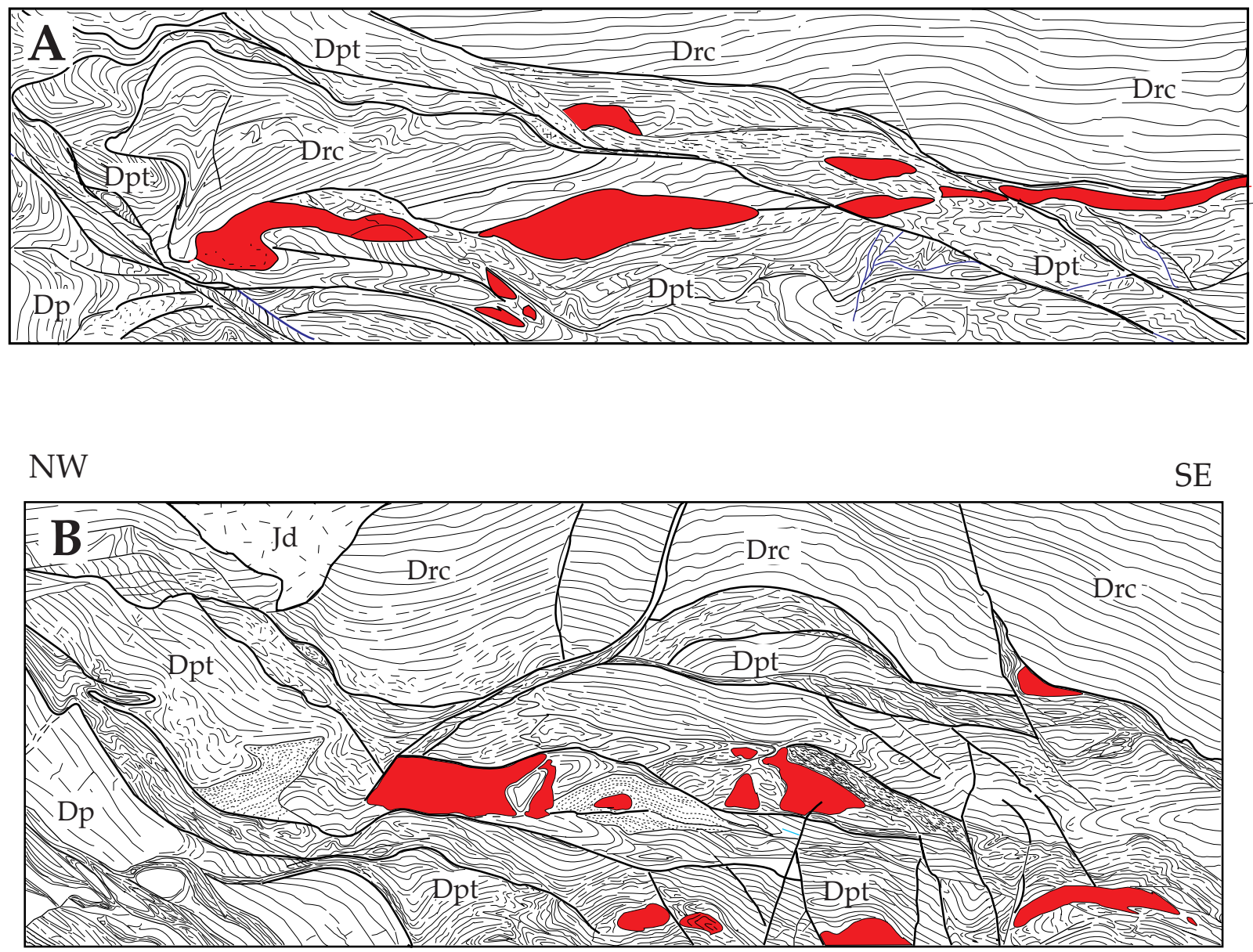

\section{EXPLANATION}

\begin{tabular}{ll}
\hline Jd & Diorite (Jurassic) \\
\hline Drc & Rodeo Creek unit (Devonian) \\
\hline Dpt & Transitional zone at Drc-Dp contact \\
\hline Dp & Popovich limestone (Devonian) \\
\hline
\end{tabular}

Rutile-bearing siliceous oreshoots form lines

(bedding and foliation)

fault and major contacts

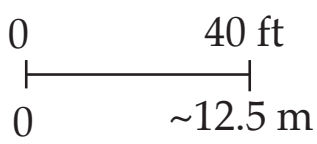

Figure 13. Bench sketches of the transitional contact between the Rodeo Creek unit and Popovich limestone, upper central Betze orebody between 4,800 and 4,900 ft levels, showing location of rutile-bearing siliceous breccia oreshoots. Sketches are roughly parallel with the WNW strike of the orebody (see Fig. 6B for locations). Main strand of the Dillon deformation zone (DDZ) is in lower left corner of sketches. Dark pods are rutile-bearing siliceous breccia pods, which contain Ti, P, REE, and U minerals. Modified from Peters (1996, 1997a). 

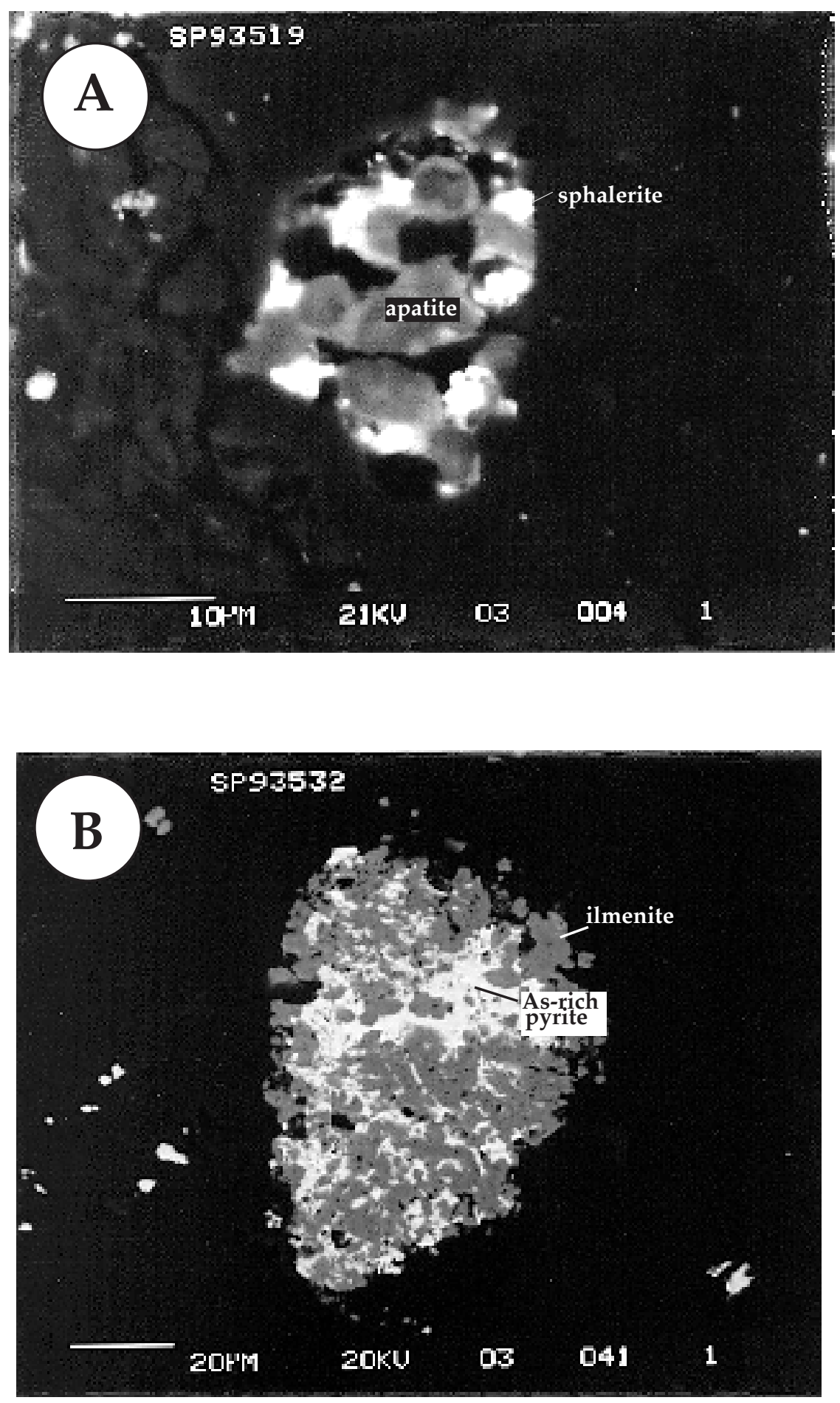

Figure 14. Scanning-electron-microscope back scatter images of some sulfide mineral textures in rutile-bearing siliceous breccia pods. The mottled, spongy textures with pyrite, sphalerite and Ti or $\mathrm{P}$ minerals are common in the siliceous breccia pods, but are rare elsewhere in the orebody. (A) Sphalerite (bright mineral) over-growing pisolitic phosphate mineral. (B) Pyrite (bright) and rutile (gray) intergrowths. 
Table 2. Characteristics of oreshoots, Betze orebody, northern Nevada

\begin{tabular}{|c|c|c|c|c|c|c|c|c|c|c|}
\hline $\begin{array}{l}\text { Oreshoot } \\
\text { type }\end{array}$ & $\begin{array}{l}\text { Position } \\
\text { in orebody }\end{array}$ & $\begin{array}{l}\text { Main host } \\
\text { rocks }\end{array}$ & Sizes & $\begin{array}{l}\text { Texture, } \\
\text { rock type }\end{array}$ & Shape & $\begin{array}{l}\text { Typical } \\
\text { minerals }\end{array}$ & $\begin{array}{l}\text { Pyrite } \\
\text { types }\end{array}$ & Qtz types & $\begin{array}{c}\text { Cross- } \\
\text { cutting } \\
\text { relations }\end{array}$ & $\begin{array}{l}\text { Geochemici } \\
\text { signature } \\
\text { [Grade] } \\
\end{array}$ \\
\hline $\begin{array}{l}\text { Rutile-bearing } \\
\text { oreshoots }\end{array}$ & $\begin{array}{l}\text { hangingwall, } \\
\text { upper central, } \\
300-\mathrm{m} \text {-long zone }\end{array}$ & $\begin{array}{l}\text { transitional } \\
\text { contact } \\
\text { between Drc } \\
\text { and Dp }\end{array}$ & $\begin{array}{l}40 \text { to } 6 \mathrm{~m} \\
\text { long, } 2 \text { to } 15 \\
\mathrm{~m} \text { wide }\end{array}$ & $\begin{array}{l}\text { rip up, } \\
\text { collapse, } \\
\text { tectonic } \\
\text { brx and } \\
\text { fossil hash }\end{array}$ & $\begin{array}{l}\text { oblate pods } \\
\text { in clusters }\end{array}$ & $\begin{array}{l}\text { qtz, zircon, } \\
\text { ilmenite, titanite, } \\
\text { pisolitic magnetite, } \\
\text { ilmenite, rutile, } \\
\text { apatite, REE } \\
\text { minerals, py, As- } \\
\text { rich py, rutile }\end{array}$ & $\begin{array}{l}\text { disseminated } \\
\text { radiating As- } \\
\text { rich py }\end{array}$ & $\begin{array}{l}\text { cryptocrystalline } \\
\text { groundmass and } \\
\text { flooding, } 0.5 \text { to } \\
1.0 \mathrm{~mm} \text { thick } \\
\text { veinlets }\end{array}$ & $\begin{array}{l}\text { possibly } \\
\text { cross cuts } \\
\text { illite-clay } \\
\text { py ores, or } \\
\text { may be } \\
\text { coeval }\end{array}$ & $\begin{array}{l}\mathrm{Au}, \mathrm{Fe}, \mathrm{P} \\
{[0 . .5 \text { to } 2.0 \mathrm{o}:} \\
\mathrm{Au} / \mathrm{t}][15.5 \\
64 \mathrm{~g} / \mathrm{t} \mathrm{Au}]\end{array}$ \\
\hline $\begin{array}{l}\text { Illite-clay pyrite } \\
\text { oreshoots }\end{array}$ & $\begin{array}{l}\text { central upper } \\
\text { DDZ, main ore } \\
\text { type }\end{array}$ & $\begin{array}{l}\text { Dp, (Drc, Drm, } \\
\text { Jd) }\end{array}$ & $\begin{array}{l}2 \text { to } 10 \mathrm{~m} \\
\text { thick, } 5 \text { to } \\
50 \mathrm{~m} \text { long }\end{array}$ & $\begin{array}{l}\text { brx and } \\
\text { phyllonite, } \\
\text { folding }\end{array}$ & $\begin{array}{l}\text { elongate, } \\
\text { planar, } \\
\text { beds, gouge } \\
\text { zones }\end{array}$ & $\begin{array}{l}\text { illite, qtz, clay } \\
\text { minerals, As-rich } \\
\text { py, carbon }\end{array}$ & $\begin{array}{l}\text { disseminated } \\
0.01 \text { to } 2 \mathrm{~mm} \\
\text { euhedral to } \\
\text { subhedral } \\
\text { grains and } \\
\text { grain } \\
\text { aggregates }\end{array}$ & $\begin{array}{l}1 \mathrm{~mm} \text { to } 1 \mathrm{~cm} \\
\text { thick crystalline } \\
\text { veinlets, some } \\
\text { silica flooding }\end{array}$ & $\begin{array}{l}\text { cross cut } \\
\text { by all other } \\
\text { ore types }\end{array}$ & $\begin{array}{l}\mathrm{Hg}, \mathrm{Cr}, \mathrm{Zn}, \\
\mathrm{Cu}, \mathrm{Ba}, \mathrm{Ni}, \mathrm{\prime} \\
(\mathrm{Cr}, \mathrm{P}, \mathrm{Ti}) \\
{[3.2 \text { to } 7.8 \mathrm{~g} \text { / }} \\
\mathrm{Au}]\end{array}$ \\
\hline $\begin{array}{l}\text { Realgar- and } \\
\text { orpiment- } \\
\text { bearing } \\
\text { oreshoots }\end{array}$ & $\begin{array}{l}\text { footwall, Jd } \\
\text { contact, above } \\
\text { stibnite- barite- } \\
\text { rich ores }\end{array}$ & $\begin{array}{l}\text { contact zone of } \\
\text { Jd, brx hornfels, } \\
\text { Dp }\end{array}$ & $\begin{array}{l}150 \text { to } 6 \mathrm{~m} \\
\text { long, } 30 \mathrm{~m} \\
\text { thick }\end{array}$ & $\begin{array}{l}\text { phyllonite, } \\
\text { brx, folding }\end{array}$ & $\begin{array}{l}\text { domal, } \\
\text { stratabound }\end{array}$ & $\begin{array}{l}\text { realgar, orpiment, } \\
\text { py, marcasite, } \\
\text { calcite, apatite }\end{array}$ & $\begin{array}{l}\text { disseminated } \\
\text { both low and } \\
\text { high As py }\end{array}$ & $\begin{array}{l}\text { qtz hornfels brx } \\
\text { fragments, local } \\
\text { microcrystalline- } \\
\text { textured qtz } \\
\text { flooding }\end{array}$ & $\begin{array}{l}\text { cross cuts } \\
\text { illite clay } \\
\text { ores }\end{array}$ & $\begin{array}{l}\text { As, } \mathrm{Au}, \mathrm{Sb} \\
0.1 \text { to } 1 \mathrm{oz} \\
\mathrm{Au} / \mathrm{t}][<32 \mathrm{~g} \\
\mathrm{Au}]\end{array}$ \\
\hline $\begin{array}{l}\text { Stibnite- } \\
\text { bearing- } \\
\text { oreshoots }\end{array}$ & $\begin{array}{l}\text { central lower } \\
\text { parts, below } \\
\text { realgar- orpiment- } \\
\text { rich ores }\end{array}$ & $\begin{array}{l}\text { Dp, Drm, } \\
\text { contact zone } \\
\text { of Jd }\end{array}$ & $\begin{array}{l}70 \times 200 \mathrm{~m}, \\
1,000 \mathrm{~m} \text { long } \\
\text { zone }\end{array}$ & $\begin{array}{l}\text { crackle, } \\
\text { collapse } \\
\text { and } \\
\text { tectonic } \\
\text { brx }\end{array}$ & $\begin{array}{l}\text { domal, } \\
\text { arcuate, } \\
\text { irregular, } \\
\text { stratabound }\end{array}$ & $\begin{array}{l}\text { qtz, stibnite, barite, } \\
\text { boulangerite, } \\
\text { sphalerite. }\end{array}$ & $\begin{array}{l}\text { pre-silica As- } \\
\text { rich py, post- } \\
\text { silica } \\
\text { marcasite-qtz } \\
\text { veinlets }\end{array}$ & $\begin{array}{l}\text { intense silica } \\
\text { flooding, } \\
\text { microcrystalline } \\
\text { texture; } 2 \text { to } 3 \\
\text { additional } \\
\text { episodes of both } \\
\text { clear and milky } \\
\text { veining }\end{array}$ & $\begin{array}{l}\text { cross cuts } \\
\text { illite-clay } \\
\text { py ores; in } \\
\text { contact } \\
\text { with } \\
\text { realgar- } \\
\text { orpiment- } \\
\text { rich ores }\end{array}$ & $\begin{array}{l}\mathrm{Au}, \mathrm{Sb}, \mathrm{Ba} \\
(\mathrm{Zn}, \mathrm{Hg}, \mathrm{Tl}, \\
\mathrm{As}) \\
{[<0.1 \mathrm{oz} \mathrm{Au}} \\
{[3.2 \mathrm{~g} / \mathrm{t} \mathrm{Au}]}\end{array}$ \\
\hline $\begin{array}{l}\text { Polymetallic } \\
\text { oreshoots }\end{array}$ & $\begin{array}{l}\text { footwall, adjacent } \\
\text { to Jd contact }\end{array}$ & $\begin{array}{l}\mathrm{Dp} \text {, contact } \\
\text { zone of Jd }\end{array}$ & $\begin{array}{l}10 \text { to } 30 \mathrm{~m} \\
\text { long } 5 \text { to } 10 \\
\mathrm{~m} \text { wide }\end{array}$ & sulfidic brx & $\begin{array}{l}\text { irregular } \\
\text { pods }\end{array}$ & $\begin{array}{l}\text { cinnabar, } \\
\text { sphalerite, } \\
\text { chalcopy, galena, } \\
\text { silver minerals, } \\
\text { apatite, Fe oxide } \\
\text { minerals in } \\
\text { microvugs. }\end{array}$ & $\begin{array}{l}\mathrm{Hg}-\mathrm{Cu}-\text {, } \\
\text { and } \mathrm{Pb}-\mathrm{rich} \\
\text { rimmed py, } \\
\text { remnant As- } \\
\text { rich py }\end{array}$ & $\begin{array}{l}\text { some silica } \\
\text { flooding, veinlets } \\
\text { rare }\end{array}$ & $\begin{array}{l}\text { cross cuts } \\
\text { illite clay } \\
\text { py, } \\
\text { realgar- } \\
\text { orpiment- } \\
\text { rich, and } \\
\text { stibnite- } \\
\text { barite-rich } \\
\text { ores } \\
\end{array}$ & $\begin{array}{l}\mathrm{Au}, \mathrm{Ba}, \mathrm{Cu}, \\
\mathrm{Hg}, \mathrm{Zn}, \mathrm{Ni}, \\
\mathrm{Ag}, \mathrm{As},(\mathrm{P}, \\
\mathrm{REE}, \mathrm{U}, \mathrm{Se},] \\
\mathrm{Cd}, \mathrm{Tl}) . \\
{[>0.5 \mathrm{oz} \mathrm{Au}} \\
{[15.5 \mathrm{~g} / \mathrm{t} \mathrm{Al}}\end{array}$ \\
\hline
\end{tabular}

Drc - Rodeo Creek unit; Dp - Popovich limestone; Drm - Roberts Mountains Formation; Jd - Goldstrike Jd; brx - breccia; py - pyrite; qtz - quartz. DDZ - Dillon deformation zone. 
cryptocrystalline groundmass. These pre-gold minerals were common nucleation sites for As-rich pyrite and sphalerite during the main gold event.

Individual rutile-bearing siliceous oreshoots consist of tectonic breccia, fossil hash, or sedimentary breccia and contain collapse features present in an interval about $1 \mathrm{~m}$ above the oreshoots. Silicification consists of a pervasive dark, cryptocrystalline groundmass and replacement of clasts, and late 0.5 - to $10-\mathrm{mm}$-thick, clear or opaque quartz veinlets. Pyrite is present as disseminations throughout the cryptocrystalline quartz and in veinlets as elongate vein-parallel aggregates of As-rich pyrite and hydrothermal rutile. The rutile is presumably derived from the local detrital ilmenite in the wall rock.

\section{Illite-Clay-Pyrite Oreshoots}

Illite-clay altered rocks with disseminated pyrite and carbonaceous material comprise the largest volume of ore in the upper central Betze orebody (Fig. 12). They form as locally siliceous, brecciated, illite-clay-pyrite bodies mainly present in the DDZ. The lower parts of the orebody have less abundant illite-clay alteration and are more typically silicified breccias. This type of ore predates all but the rutile-bearing siliceous oreshoots. Because illite-claypyrite alteration and mineralization are paragenetically early, this type of ore forms a mesoscopic and microscopic matrix oreshoots that were superimposed over the illite-claypyrite ores. Pods of illite-clay-pyrite ores that were not replaced by later ores have been locally structurally isolated along strands of the DDZ and form individual oreshoots. Other illite-clay-pyrite bodies commonly wrap around the other oreshoots in gouge-filled or phyllonitic seams. Most illite-clay-pyrite oreshoots contain 0.10 to $0.25 \mathrm{oz} \mathrm{Au} / \mathrm{t}(\sim 3.2$ to 7.8 $\mathrm{g} \mathrm{Au} / \mathrm{t})$. Geochemically this ore type has high values of $\mathrm{Cr}, \mathrm{Zn}, \mathrm{Fe}, \mathrm{Ba}, \mathrm{Ti}$, and $\mathrm{Cu}$ with local $\mathrm{Ba}, \mathrm{Ni}$, and $\mathrm{V}$ (table 3 ). The oreshoots commonly are isolated from one another, and from other oreshoot types low-grade zones (Figs. 6A,B and 11; table 2). Three main textural types include: (1) disseminated As-rich pyrite in relatively undeformed, unbrecciated decalcified limestone and silty limestone (Fig. 15A); (2) tectonized, phyllonitic rock, with disseminated gold-bearing As-rich pyrite contained in and peripheral to broken quartz veinlets (Fig. 15B); and (3) structurally complex isolated, commonly silicified, polygenetic breccia (Figs. 15C and D). The ores typically are tectonized, dark, black, sulfide- and carbon-bearing, and are locally but intensely phyllonitic. Where bedding is recognizable, intense folding is common. Black and gray, 10- to 50-cm-thick illite-clay-rich oreshoots contain soft dense gouge and breccia that commonly parallel the phyllonitic fabric or bedding on the flanks of isoclinal folds. Sedimentary bedding slip zones are common and are filled with phyllonitic gouge.

Pyrite is disseminated throughout the illite-clay-pyrite oreshoots in several textural forms and generations, including $0.01-$ to $2-\mathrm{mm}$-size euhedral crystals, anhedral grains and grain aggregates (Figs. $10 \mathrm{~A}, \mathrm{~B}$, and 15A, B, C). Pyrite is closely related to $1-\mathrm{mm}$ to $1-\mathrm{cm}-$ thick cryptocrystalline quartz veinlets that typically parallel the phyllonitic matrix and are typically broken or dismembered. Arsenic-rich pyrite is present as felt-textured grains in the quartz veinlets and as $<0.01-\mathrm{mm}$-diameter disseminated grains and aggregates in phyllonitic wall rock. Gold is micron sized and commonly is contained in 1- to 10- $\mu$ m-thick As-rich rims on pyrite (Arehart, 1993a). Gold distribution in these oreshoots is not uniform. 
Illite-clay-rich, cataclastic, pyritic, gold-rich zones and breccia pods are common constituents of illite-clay-pyrite oreshoots in the hanging wall of the orebody in the DDZ; whereas in the footwall, unmineralized marble and limestone form mesoscopic phacoids that are separated by conjugate and anastamosing, gray, illite-clay seams. These breccia bodies represent silicified end members of dissolution and collapse, cataclasis, fossil hash, sedimentary breccia and combinations of these primary breccia types that have been dismembered and isolated by shearing and folding in the DDZ. These features are compatible with significant movement during formation of illite-clay-pyrite oreshoots, but prior to the formation of some other oreshoots.

\section{Realgar- and Orpiment-Bearing Oreshoots}

Realgar- and orpiment-bearing oreshoots (arsenic seam ore of Peters, 1996, 1997a) contain abundant masses of realgar and orpiment, but also contain disseminated pyrite and marcasite and some apatite (table 2). This ore type result from deposition of these minerals on earlier formed zones of illite-clay-pyrite ore. The oreshoots were most common in the upper central Betze orebody in a 30- to 50-m-size zone away from the diorite contact, spatially associated with diorite apophyses or with contact metamorphic or metasomatic zones, or surrounding and lying above domal-shaped siliceous stibnite-bearing siliceous oreshoots (Figs. 11, 12, and 16A). The realgar- and orpiment-bearing oreshoots are composed of dark gray to black, decalcified, tectonized seams of sheared limestone and calcsilicate rock that surround unmineralized undeformed phacoids of crystalline, white limestone and marble (Fig. 17A, B). In the southeastern upper central Betze orebody, realgar-and orpiment-bearing oreshoots average about $1 \mathrm{oz} A u / t ~(\sim 32 \mathrm{~g} \mathrm{Au} / \mathrm{t})$. The unmineralized nature of the limestone phacoids, which are 40 to 60 percent of the volume, suggest that the realgar-orpiment seams average greater than 2 oz Au/t ( 64 g Au/t) (Fig. $17 \mathrm{~B}$; table 2). Realgar- and orpiment-bearing ores peripheral to the main orebody have low or trace amounts of gold, suggesting that much of the gold may be contained in illite-claypyrite ores that were overprinted by the later realgar and orpiment.

Realgar usually is stratabound, but has a tendency at hand specimen-scale to form cross-cutting textures - especially in siliceous zones or in breccia fragments-which indicate small-scale injection or veining, whereas orpiment masses generally have more conformable replacement-style textures (Fig. 17C). Realgar also is present as 0.5 - to 5-cm-thick seams replacing bedding planes and phyllonitic layers and as $0.1-$ to $0.5-\mathrm{mm}$-diameter disseminated crystals. Disseminated realgar also is present as 1 - to 5-mm-diameter aggregates, as inclusions inside orpiment crystals, as replacements of fossil shells, and as rims on orpiment. Orpiment is more commonly associated with calcite than realgar and typically is present as rounded, more massive, 0 . 5- to 1-cm-diameter radiating crystals; it also is present as disseminated $0.01-$ to $0.1-\mathrm{mm}$-diameter crystal aggregates, as interstitial crystals in calcite masses, in 1- to 10-mm-thick veinlets, as growths around low-As pyrite, and as growths around breccia clasts. 

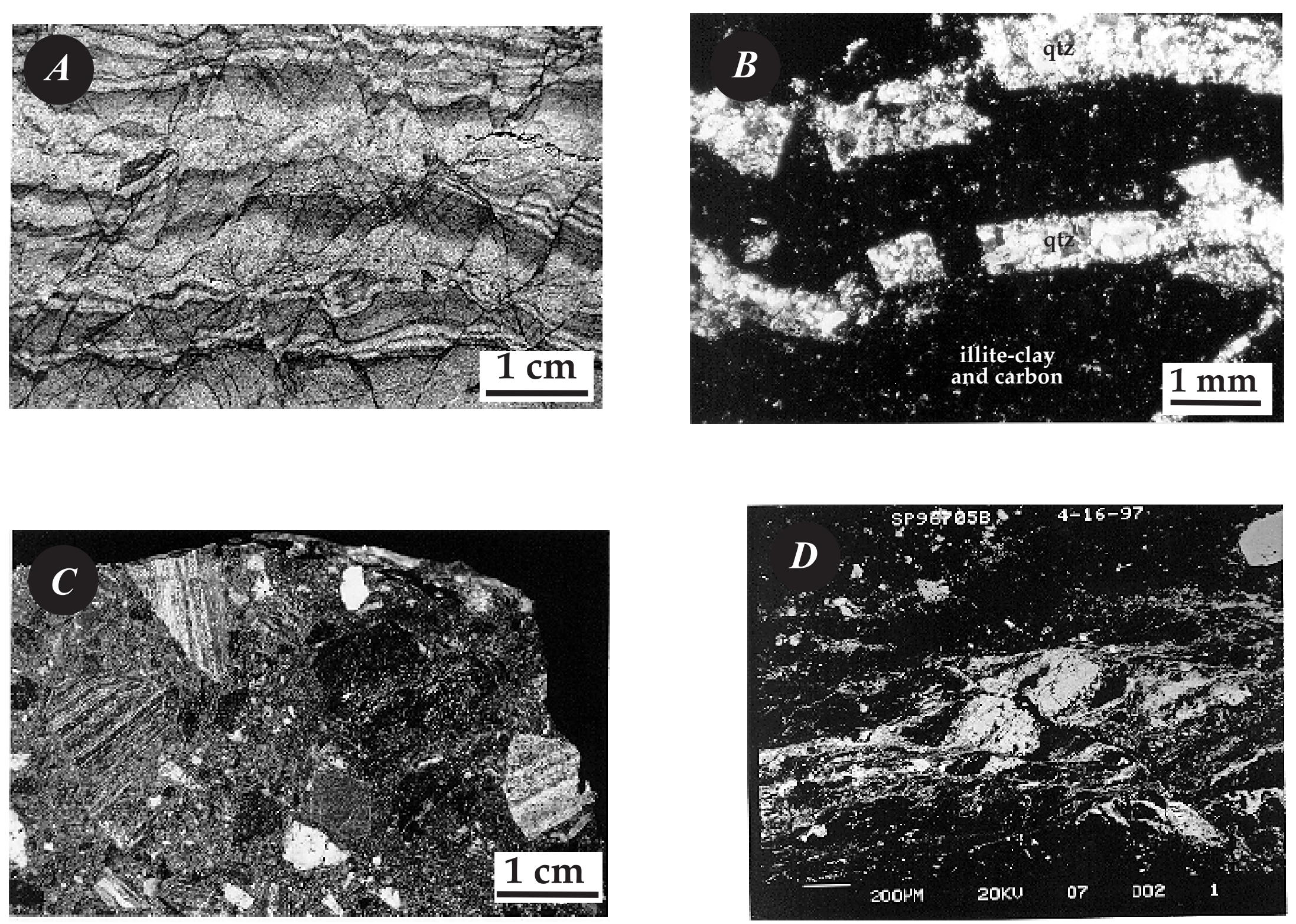

Figure 15. Variety of ore textures in illite-clay-pyrite oreshoots (Fe-rich) in the main parts of the Betze orebody. (A) disseminated As-rich pyrite in relatively undeformed, laminar Popovich limestone. (B) Broken 1.5-mm-thick main gold-stage quartz veinlets parallel to phyllonitic fabric in carbonaceous shear zone that contains disseminated micron-scale As-rich pyrite. (C) Heterolithic breccia. As-rich pyrite is present both in clasts and matrix. Breccias may be the result of primary debris flows, dissolution and collapse, or tectonism (see Peters and others, 1997). (D) Syndeformational As-rich, brecciated pyrite deposited along phyllonitic illite-clay seam in oriented matrix between clasts of brecciated and altered lamprophyre. Arsenic-rich rims on brecciated pyrite show oscillatory zoning. 



\section{EXPLANATION}

Jd Diorite (Jurassic)

ls Limestone or marble (Devonian and Jurassic)

In: Illite-clay-pyrite, carbonaceous tectonized ores

CSbo Stibnite- and barite-

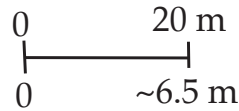
rich breccia

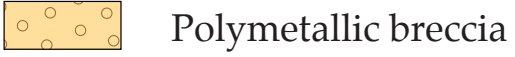

Figure 16. Bench sketches parallel to strike of the Betze orebody showing section of vertical zoning of oreshoots between 4,800 and 4,900 levels. (A) 10,200E, showing realgar- and orpiment-bearing ores associated with diorite apophyses. These As-rich ores overprint and lie below illite-clay-pyrite ores. Stibnite-bearing siliceous breccia ores lie below the As-rich ores. (B) 10,600 E, showing polymetallic breccia ores along the contact of the diorite. These ores overprint other ore types. See Fig. $6 \mathrm{~B}$ for locations. 

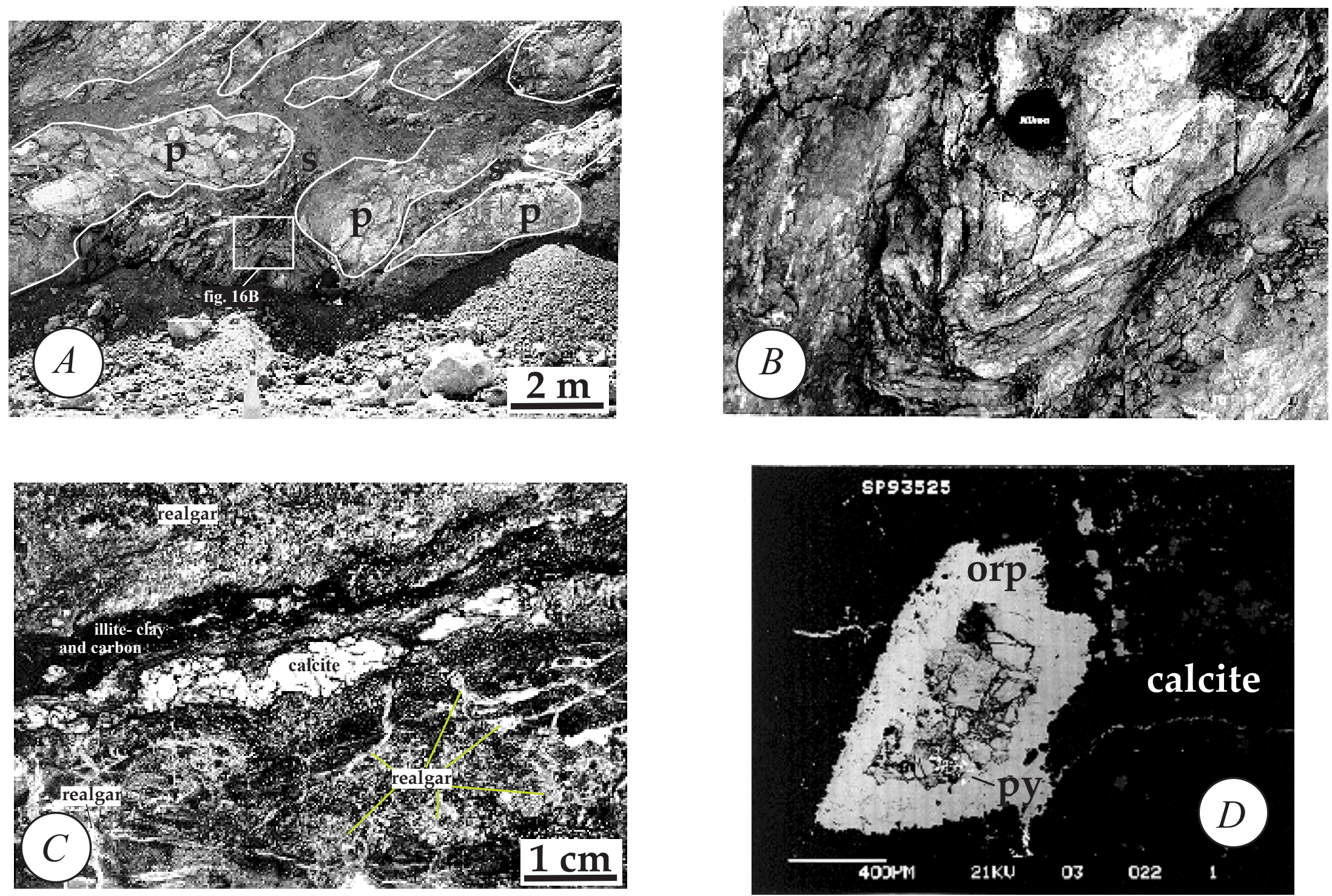

Figure 17. Textures and morphology of realgar-and orpiment-bearing ore at different scales. (A) Seams that assay greater than $1 \mathrm{oz} / \mathrm{t} \mathrm{Au}$, filled with realgar and orpiment, surrounding barren phacoids of marble. P - phacoid; S - seam. (B) Close up of folded realgar- and orpiment-bearing ore [from inset (A)]. (C) Phyllonitic seams of carbonaceous illite-clay, quartz, realgar and cross-cutting veinlets of orpiment. Field of view $7 \mathrm{~cm}$. (D) Scanning-electron-microscope back scatter image of low-arsenic pyrite crystals (small bright dots) encased in an orpiment crystal. 
Table 3. Selected elements in types of oreshoots, Betze deposit, northern Nevada

Analysis conducted by strong 4-acid digestion followed by ICP determination of 35 elements (ACME Laboratories) and andoxidized HCL digestion with organic solvent extraction with ICP and GFFAA analysis, $\mathrm{U}$

\begin{tabular}{|c|c|c|c|c|c|c|c|c|c|c|c|c|c|c|c|c|c|c|c|c|c|c|c|c|c|}
\hline $\begin{array}{l}\text { imple } \\
\text { Imber }\end{array}$ & $\begin{array}{c}\mathbf{A u} \\
\text { ppb }\end{array}$ & $\begin{array}{c}\text { As } \\
\text { ppm }\end{array}$ & $\begin{array}{c}\text { Ba } \\
\text { ppm }\end{array}$ & $\begin{array}{c}\mathbf{F e} \\
\text { ppm }\end{array}$ & $\begin{array}{c}\text { Sb } \\
\text { ppm }\end{array}$ & $\begin{array}{l}\mathrm{Hg} \\
\text { ppm }\end{array}$ & $\begin{array}{l}\mathbf{S} \\
\%\end{array}$ & $\begin{array}{c}\mathbf{Z n} \\
\text { ppm }\end{array}$ & $\begin{array}{c}\mathbf{P b} \\
\text { ppm }\end{array}$ & $\begin{array}{l}\mathbf{T i} \\
\%\end{array}$ & $\begin{array}{c}\mathbf{P} \\
\mathbf{p p m}\end{array}$ & $\begin{array}{l}\mathrm{Cu} \\
\text { ppm }\end{array}$ & $\begin{array}{l}\mathrm{C} \\
\%\end{array}$ & $\begin{array}{c}\mathrm{Cr} \\
\text { ppm }\end{array}$ & $\begin{array}{l}\text { Co } \\
\text { ppm }\end{array}$ & $\begin{array}{c}\mathrm{Ni} \\
\mathrm{ppm}\end{array}$ & $\begin{array}{l}\mathbf{C a} \\
\%\end{array}$ & $\begin{array}{l}\mathbf{K} \\
\%\end{array}$ & $\begin{array}{c}\mathbf{M g} \\
\%\end{array}$ & $\begin{array}{c}\text { Ag } \\
\text { ppm }\end{array}$ & $\begin{array}{c}\text { Cd } \\
\text { ppm }\end{array}$ & $\begin{array}{c}\text { TI } \\
\text { ppm }\end{array}$ & $\begin{array}{l}\overline{T h} \\
\text { pm }\end{array}$ & $\begin{array}{c}\mathbf{U} \\
\mathbf{p p m}\end{array}$ & $\mathbf{V}$ \\
\hline \multicolumn{26}{|c|}{ Rutile-bearing ores } \\
\hline & 9200 & 3100 & 32 & 34 & 310 & 300 & 3.43 & 47 & 7 & 0.04 & 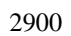 & 21 & 003 & 24 & 200 & 360 & & & & & 4 & 35 & & $<100$ & \\
\hline & $1 \zeta$ & 530 & 630 & 9300 & 110 & 3. & 0.27 & 18 & & 0.02 & 1500 & 13 & 0.3 & 1 & 1 & 6 & & & & 0. & 1 & 3.8 & & $<100$ & \\
\hline 3 & 2500 & 330 & 3600 & 11000 & 50 & 2.2 & 05 & 300 & 6 & 0.12 & 2400 & 23 & 1.33 & 44 & 14 & 75 & 0.14 & 0.8 & 0.09 & 0.9 & 2 & 2.1 & & 100 & \\
\hline 93542 & 500 & 90 & 3400 & 2700 & 32 & 1.2 & 0.14 & 43 & 9 & 0.007 & 600 & 23 & 0.05 & 8 & 0.1 & 16 & 0.31 & 0.07 & 0.03 & 0.14 & 11 & 0.4 & 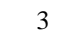 & $<100$ & \\
\hline 893545 & 50 & 420 & 2200 & 25000 & 120 & 1.2 & 0.16 & 330 & 22 & 0.09 & 1400 & 48 & 0.05 & 110 & 62 & 220 & 0.18 & 1.7 & 0.25 & 0.07 & & 2.2 & 5 & $<100$ & \\
\hline
\end{tabular}

\section{Illite-clay-pyrite ores}

\begin{tabular}{|c|c|c|c|c|c|c|c|c|c|c|c|c|c|c|c|c|c|c|c|c|c|c|c|c|c|}
\hline \multicolumn{26}{|c|}{ Illite-clay-pyrite ore } \\
\hline SP9401 & 19600 & 710 & 100 & 9400 & 36 & 260 & 0.77 & 133 & 6 & 0.03 & 390 & 19 & 0.2 & 280 & 1 & 15 & 0.28 & 0.1 & 0.07 & 1.6 & 1.1 & NA & 1.5 & $<0.6$ & 25 \\
\hline P9404 & 180 & 1700 & 870 & 17900 & 170 & 16 & 1.9 & 4456 & 11 & 0.19 & 4420 & 48 & 0.1 & 250 & 25 & 431 & 89 & 0.2 & 6 & 2.9 & 36.8 & NA & 6.1 & 78 & 3813 \\
\hline $9406 f$ & 25600 & 1200 & 310 & 14900 & 100 & 98 & 1.08 & 1272 & 12 & 0.1 & 2460 & 78 & 1.8 & 250 & 14 & 199 & 75 & 0.53 & 14 & 3.1 & 10 & NA & 7 & 22 & 750 \\
\hline $99406 \mathrm{E}$ & 12600 & 500 & 170 & 9400 & 94 & 87 & 0.86 & 3689 & 13 & 0.09 & 3560 & 54 & 0.6 & 290 & 6 & 92 & 1 & 0.26 & 0.07 & 2 & 10.5 & NA & 2.7 & 45 & 318 \\
\hline 99407 & 6420 & 250 & 330 & 10800 & 92 & 15 & 0.04 & 716 & 5 & 0.05 & 7360 & 26 & 0.4 & 370 & 5 & 147 & 1.97 & 0.11 & 0.07 & 3.8 & 1.6 & NA & 2.2 & 34 & 102 \\
\hline 994013 & 1970 & 300 & 400 & 13400 & 330 & 0.1 & 1.29 & 63 & 5 & 0.17 & 740 & 49 & 5.4 & 190 & 4 & 54 & 23 & 1.38 & 0.2 & 2 & 4.9 & NA & 5.9 & 33 & 638 \\
\hline 994014 & 1780 & 250 & 410 & 12900 & 350 & 5 & 1.16 & 79 & 9 & 0.16 & 620 & 52 & 5.8 & 200 & 4 & 60 & 19 & 1.3 & 0.28 & 1.4 & 3.7 & NA & 4.8 & 38 & 626 \\
\hline 994015 & 123 & 470 & 260 & 30900 & 150 & 9 & 2.89 & 33 & 15 & 0.25 & 930 & 69 & 6.4 & 190 & 8 & 139 & 0.32 & 0.56 & 0.26 & 2 & 0.6 & NA & 9.1 & 64 & 776 \\
\hline 93514 & 4300 & 200 & 85 & 9500 & 60 & 20 & 1.16 & 3600 & 1 & 0.14 & 1200 & 140 & 29 & 150 & 3 & 210 & 0.24 & 0 & 1 & 2.4 & 39 & 6.8 & 4 & 100 & 3800 \\
\hline 8 & 50 & 2800 & 150 & 25000 & 130 & 7.5 & 1.89 & 390 & 7 & 0.37 & 1200 & 53 & .26 & 100 & 13 & 93 & 8.1 & 1.8 & 3.7 & 0.3 & 1 & 8.4 & 14 & 100 & 270 \\
\hline 93518 & 800 & 540 & 140 & 8900 & 29 & 3.4 & 0.39 & 110 & 3 & 0.05 & 3200 & 10 & 7.7 & 24 & 4 & 19 & 15 & 0.14 & 0.61 & 0.07 & 1 & 2. & 3 & $<100$ & 86 \\
\hline \multicolumn{26}{|c|}{ Realgar- and orpiment-bearing ore } \\
\hline 24 & 37000 & $2 \mathrm{E}+05$ & 15 & 14000 & $>1500$ & 0.5 & 10.9 & 490 & 7 & 0.09 & 1100 & 44 & 1.49 & 37 & 3 & 37 & 5.1 & 0.25 & .09 & 0.07 & 16 & 70 & 3 & $<100$ & 89 \\
\hline 93 & 64000 & $1 E+05$ & 73 & 30000 & 00 & 300 & 11.7 & 110 & 17 & 0.12 & 400 & 200 & & 48 & 4 & 57 & 0.14 & 0.5 & 0.11 & 07 & 1 & 150 & 5 & $<100$ & 170 \\
\hline 93526 & 2800 & $4 \mathrm{E}+05$ & 26 & 5400 & 1500 & 300 & 29.6 & 9 & 5 & 0.07 & 200 & 12 & 0.3 & 28 & 0.1 & 12 & 4 & 0.2 & 0.1 & 0.0 & 1 & 15 & 3 & $<100$ & 62 \\
\hline P93527 & 3400 & $4 \mathrm{E}+05$ & 32 & 11000 & 1500 & 300 & 21.4 & 19 & 13 & 0.15 & 700 & 18 & 0.5 & 40 & 3 & 22 & 0.46 & 0.54 & 0.22 & 0.07 & 1 & 20 & 6 & $<100$ & 61 \\
\hline 94103 & 610 & $3 E+05$ & 0 & 5200 & 00 & 62 & 9.51 & 16 & 5 & 0 & 770 & , & 0.2 & 1 & $<1$ & 7 & 0.66 & 0.1 & 2 & $<0.4$ & $<0.5$ & NA & $<0.4$ & $<6.2$ & 10 \\
\hline 994104 & 8420 & $2 \mathrm{E}+05$ & 2800 & 11800 & 1700 & 110 & 8.5 & 23 & 6 & 0.08 & 280 & 18 & 1. & 180 & 4 & 13 & .63 & 0.42 & & 0.4 & $<0.5$ & NA & $<0.4$ & $<6.2$ & 19 \\
\hline 94106 & 5170 & 43000 & 70 & 4700 & 62 & 29 & 2.76 & 59 & 5 & 0.02 & 820 & 5 & 2.2 & 170 & $<1$ & 6 & 6.95 & 0.09 & .25 & $<0.4$ & $<0.5$ & NA & $<0.6$ & $<2.1$ & 15 \\
\hline \multicolumn{26}{|c|}{ Stibnite-bearing siliceous ores } \\
\hline 93534 & 000 & 410 & 230 & 7700 & 500 & 3.2 & 1.66 & 110 & 3 & 0.04 & 400 & 15 & 0.05 & 32 & 3 & 12 & 0.2 & 0.4 & & 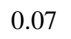 & 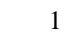 & & 3 & $<100$ & 44 \\
\hline 93535 & 4200 & 3100 & 1 & 1400 & 1500 & 5.3 & 7.89 & 5 & 3 & 0.005 & 60 & 0.1 & 0.0 & 20 & 7 & 1 & 0.01 & 0.14 & .04 & 0.07 & 3 & 1.8 & 18 & $<100$ & 10 \\
\hline P93536 & 1600 & 470 & 0.5 & 300 & 1500 & 5.5 & 7.07 & 10 & & 0.005 & 40 & 5 & 0.0 & 4 & 5 & & 0.005 & 0.03 & .01 & 0.07 & 1 & 6.1 & 16 & $<100$ & 3 \\
\hline P93540 & 11000 & 2300 & 130 & 18000 & 300 & 13 & 1.77 & 60 & 21 & 0.04 & 300 & 37 & 1.08 & 23 & 3 & 54 & 0.11 & 0.62 & 0.08 & 0.39 & 1 & 15 & 3 & $<100$ & 160 \\
\hline \multicolumn{26}{|c|}{ Polymetallic ore } \\
\hline 93519 & 5800 & 300 & 190 & 14000 & 54 & 300 & 1.38 & 480 & 15 & 0.27 & 900 & 69 & 0.0 & 91 & 23 & 96 & 17 & 0.59 & 12 & 0.36 & 1 & 45 & 8 & $<100$ & 190 \\
\hline 93520 & 13000 & 1300 & 270 & 13000 & 46 & 300 & 1.35 & 360 & 10 & 0.18 & 2700 & 29 & 0 & 56 & 22 & 72 & 0.29 & 0.19 & 8 & 0.27 & 1 & 40 & 7 & $<100$ & 140 \\
\hline 1 & 11000 & 920 & 140 & 6100 & 20 & 300 & 0.73 & 900 & 5 & 0.04 & 500 & 20 & 0.0 & 28 & 6 & 24 & 0. & 0.1 & 0.06 & 0.14 & 1 & 25 & 3 & $<100$ & 170 \\
\hline 94100 & 3530 & 300 & 00 & 9300 & 140 & 13 & 0.78 & 60 & 6 & 0.11 & 1360 & 13 & 0 & 30 & 5 & 40 & & 0.8 & 7 & 1.6 & 0.5 & NA & 5.2 & 10 & 80 \\
\hline & 5600 & 730 & 3000 & 10500 & 200 & 1 & 0.84 & 52 & 11 & 0.16 & 1700 & 25 & 0.5 & & 5 & 51 & & 0.7 & & 6.7 & 0.5 & NA & 6.9 & 9.3 & 63 \\
\hline P94102 & 14800 & 140 & 270 & 4400 & 75 & 250 & 0.1 & 216 & 6 & 0.05 & 11860 & 167 & 1 & 340 & 4 & 31 & 2.81 & 0.36 & 0.06 & 13.8 & 0.9 & NA & 3.3 & 15 & 310 \\
\hline
\end{tabular}


Pyrite in realgar and orpiment-bearing oreshoots is present in several textural habits that suggest most of it preceded realgar-orpiment-calcite precipitation. Pyrite ranges from 2 to 15 vol. percent in most ores as fine-grained disseminations in illite-clay- and silica-rich parts, as both euhedral and subhedral shapes, and as both low-As and high-As types. Coarse euhedral pyrite also is present locally. Pyrite and rare stibnite also are present as inclusions in orpiment and in vugs (Fig. 17D).

Quartz is present as blue- to gray-colored, rounded, centimeter-scale breccia fragments of silica hornfels in a matrix of orpiment, realgar, and calcite, and as microcrystalline matrix and fine-grained crystals in millimeter-scale veinlets in local siliceous breccia. Calcite is white, coarse-grained, in euhedral to subhedral crystals in veinlets and in matrix fill, and may occupy up to 10 vol. percent of the ore. Calcite typically cross cuts realgar veinlets and masses. Realgar-and orpiment-bearing oreshoots also contain local pre-gold, syn-diorite(?) scheelite as inclusions in orpiment, and locally abundant finegrained apatite near the diorite contact. Antimony and $\mathrm{Tl}$ contents locally are enriched in these oreshoots (table 3), but $\mathrm{Sb}$ and $\mathrm{Tl}$ minerals are rare, because they are possibly overprinted by realgar and orpiment, or they may also be due to the enrichment of these elements in orpiment and realgar mineral structures (see Radtke and others, 1973, 1974).

\section{Stibnite-Bearing Siliceous Oreshoots}

Stibnite-bearing siliceous oreshoots (siliceous breccia bodies of Peters, 1996, 1997a) are arcuate, homogeneous, hard, dark-gray bodies that occupy local areas in the orebody along 1,000 m of strike length (Figs. 6A, 11, 12). Gold contents of these ores is generally less than $0.1 \mathrm{oz} \mathrm{Au} / \mathrm{t}(\sim 3.2 \mathrm{~g} \mathrm{Au} / \mathrm{t}) \mathrm{Au}$, and together with the restriction of most As-rich pyrite to pre-silica clasts, suggests that these oreshoots may have overprinted the illite-claypyrite ores. The northwest end of the orebody contains a discontinuous area of stibnitebearing siliceous breccia, approximately 70 by $200 \mathrm{~m}$, surrounded on its sides and top by realgar- and orpiment-bearing ore (Fig. 6B). This stibnite-bearing siliceous breccia is in contact with diorite on its western margin, decalcified clay-altered limestone on its northwest margin, and phacoidal blocks of limestone separated by carbonaceous shear strands of the DDZ on its eastern margin. The domal shape of the tops of these oreshoots roughly conforms to bedding in the Betze anticline (Figs. 11, 12, 6A). Two other stibnite-bearing siliceous oreshoots lie in or adjacent to the DDZ in the central and southeastern parts of the upper central Betze orebody (Fig. 6B).

Textures in siliceous stibnite-bearing oreshoots resemble both crackle breccia and silicified collapse breccia and contain both hard, dense zones of silicification, and porous zones with irregular 0.1 - to $1-\mathrm{cm}$-wide voids with 0.2 - to $5-\mathrm{cm}$-diameter angular to partly rounded clasts. Silica constitutes more than $70 \mathrm{wt}$. percent of the rock and is composed of several quartz types: (1) massive cloudy, white, tan, or gray microcrystalline groundmass quartz and clast replacement quartz, possibly related to siliceous contact metamorphism or metasomatism; (2) 5- to 15-mm-thick cryptocrystalline quartz veinlets and void fillings containing pyrite; (3) veinlets of euhedral clear comb quartz containing stibnite, barite and some pyrite; and (4) late quartz veinlets with marcasite. Brecciation commonly caused 
fracturing of contact metamorphic microcrystalline quartz fragments and early quartz-pyrite veinlets.

Pyrite is present as disseminated, 0.01- to 0.3-mm-size, As-rich pyrite in quartz veinlets, cut by late gold-stage stibnite-quartz veinlets, and as euhedral to anhedral, low-As pyrite that also is coeval with barite- and stibnite-quartz. Low-As pyrite also is present as inclusions in stibnite. Some pyrite is zoned with internal layers rich in $\mathrm{Sb}$ and As and contains As-rich inner cores. Stibnite is most common in the upper 10 meters of the stibnitebearing siliceous oreshoots in subhorizontal $30-$ by $10-\mathrm{m}$-size zones. Stibnite, calcite, and barite are coarse-grained, grow into vugs among breccia fragments, and also line fractures as striated, euhedral needles. Stibnite occupies both clasts and matrices in dense silica. Stibnite also is present in clear quartz veinlets in $\mathrm{mm}-$ to $\mathrm{cm}-$ scale irregular masses and as micronscale inclusions in pyrite, as well as massive coatings or growths on euhedral pyrite crystals. Boulangerite $\left(\mathrm{Pb}_{5} \mathrm{Sb}_{4} \mathrm{~S}_{11}\right)$ and sphalerite are common $10-\mu \mathrm{m}$-size inclusions in stibnite. Planar marcasite-quartz veinlets crosscut the silica-stibnite stage. Geochemically, the ore is rich in $\mathrm{Sb}$ and $\mathrm{As}$ and moderately rich in $\mathrm{Hg}, \mathrm{Tl}, \mathrm{Ba}$, and $\mathrm{Zn}$ (table 3). The occurrence of stibnite-bearing siliceous oreshoots spatially separate from realgar- and orpiment-bearing oreshoots and the lack of cross cutting relations between them suggests that these two types of ore may be products of late zoning, which may be approximately coeval.

\section{Polymetallic Oreshoots}

Polymetallic oreshoots (sulfidic breccia pods of Peters, 1996, 1997a) form high-grade oreshoots along the diorite contact. Polymetallic oreshoots are black to dark gray, hard, irregularly shaped, $10-$ by $30-\mathrm{m}$-sized pods and siliceous breccia bodies localized by steeply-dipping, narrow, phyllonitic faults, and contain illite-clay, decalcified limestone, and silica hornfels fragments (Fig. 16). The pods are located between and over print both the upper realgar- and orpiment-bearing oreshoots and the lower siliceous stibnite-bearing oreshoots. They also cross cut the earlier illite-clay ores (Figs. 6B, 11, 12; table 2). This ore type have relatively high gold contents $[>0.15 \mathrm{oz} \mathrm{Au} / \mathrm{t}(5 \mathrm{~g} \mathrm{Au} / \mathrm{t})]$, which is due to the presence of native gold in the oxidized micro vugs, and high-sulfide content; realgar, orpiment, and stibnite are generally absent, except as earlier formed minerals that have been overprinted. These polymetallic ores are distinct from pre-gold base metal occurrences associated with diorite emplacement and clearly cross cut earlier stages of gold mineralized rocks.

Many polymetallic oreshoots coincide with high sulfide sulfur contents in blast hole assays (Figs. 6B and 7B) and commonly account for high $\mathrm{Zn}$ and $\mathrm{Cu}$ contents in the mill circuit (Barrick Goldstrike, unpub. data, 1997). Polymetallic oreshoots are typified by 10 - to 100- $\mu \mathrm{m}$-size, late gold-stage sulfide mineral aggregates containing $\mathrm{Hg}, \mathrm{As}, \mathrm{Cu}, \mathrm{Sb}, \mathrm{Zn}$, and $\mathrm{Ag}$ associated with pyrite, although the geochemical expression of these aggregates is weak (table 3). Most common are aggregate sulfide grains composed of pyrite, $\mathrm{Hg}$-rich sphalerite, chalcopyrite, and cinnabar. 

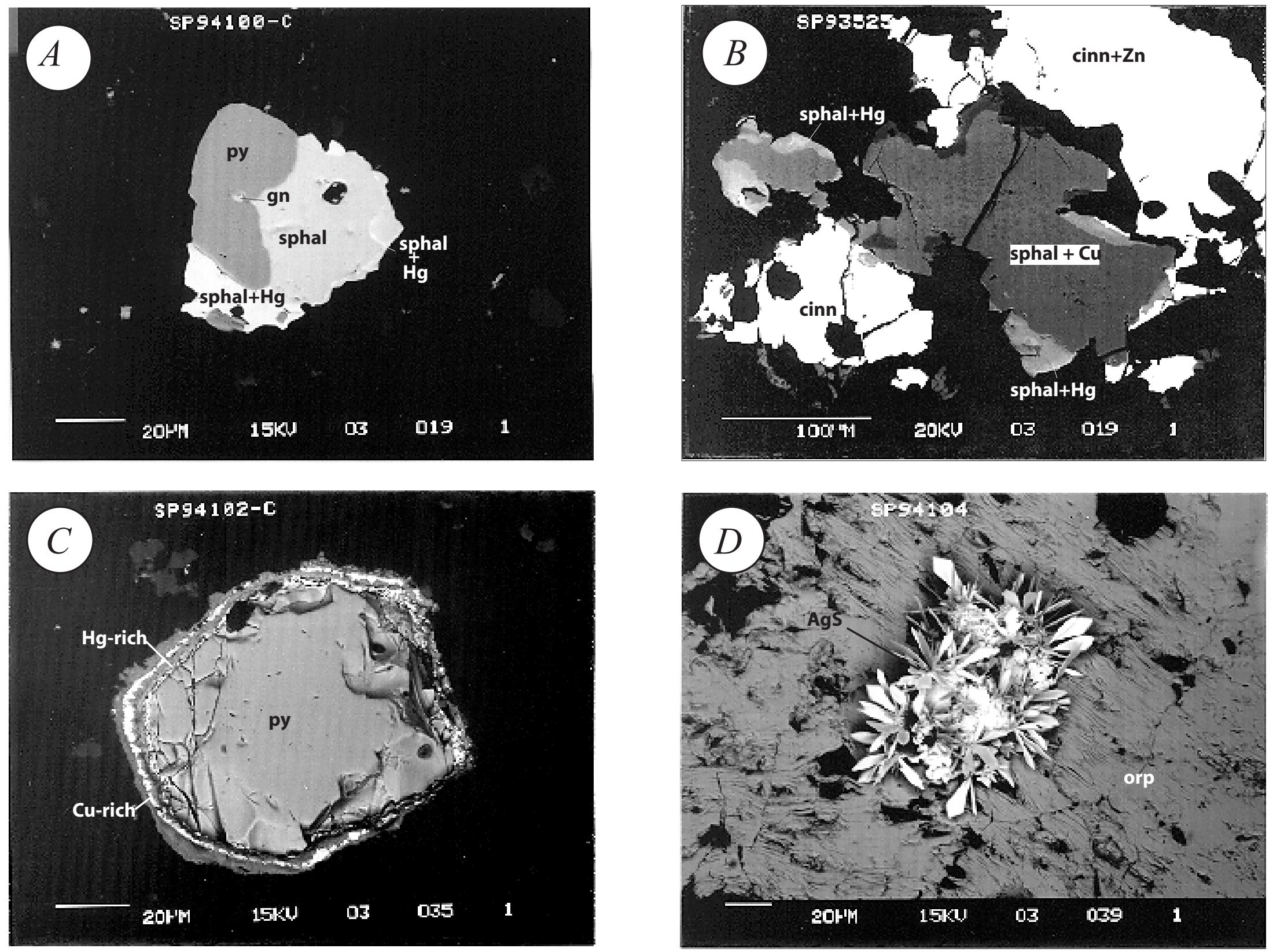

Figure 18. Scanning-electron-microscope back scatter images of typical sulfide minerals in polymetallic breccia ore. (A) Composite grain of sphalerite, $\mathrm{Hg}$-rich sphalerite, pyrite, Zn-rich cinnabar, and galena surrounded by micro-scale As-rich pyrite. (B) Composite grain of Cu-rich sphalerite, cinnabar, and pyrite. (C) Pyrite grain rimmed with chalcopyrite and cinnabar. (D) Silver sulfide in vug in realgar. Crystallinity may be due to oxidation of polished thin section. 
The variety of minerals and elements present, their the proximity to the diorite contact, and their late paragenesis are important features of the polymetallic oreshoots. These oreshoots contain the main $\mathrm{Hg}$ minerals in the Betze orebody and may be similar to the mercury ores in the Carlin deposit noted by Radtke and others (1972a,b). Cinnabar is present between crystals of realgar and as $1-$ to $2-\mu \mathrm{m}$-size rinds on pyrite-chalcopyrite grain aggregates (Figs. 18A and B). Chalcopyrite is common as disseminated euhedral to subhedral 0.1 - to $0.5-\mathrm{mm}$-diameter grains associated with illite-quartz microveinlets. Pyrite is present as anhedral, ragged $10-$ by $50-\mu \mathrm{m}$-size grains interstitial to quartz and apatite fragments in microbreccia. Arsenic-rich $1-$ to $50-\mu \mathrm{m}$-diameter, euhedral pyrite contains $\mathrm{mm}$-scale inclusions of cinnabar, fluorite, galena and sphalerite. Some pyrite contains $\mathrm{Pb}-$, $\mathrm{Hg}-$, and $\mathrm{Cu}-$ rich rims (Fig. 18C). A common feature of this ore type includes local, oxidized, 100- $\mu \mathrm{m}$-size microvugs that contain mm-size Ag sulfide (Fig. 18D), Ni and Fe

oxide minerals, $\mathrm{Cu}, \mathrm{Hg}$, Se minerals, and native $\mathrm{Au}$. Disseminated apatite is abundant in parts of the breccia bodies as 5- to 20- $\mu$ m-diameter, round crystals with cinnabar inclusions. Other trace minerals are phosphates of $\mathrm{Ce}, \mathrm{La}, \mathrm{Nd}$, and $\mathrm{U}$, abundant Ti oxide minerals, and local micron-size $\mathrm{Cd}$ and Te minerals. Geochemically, the ore is rich in $\mathrm{Ba}, \mathrm{Cu}, \mathrm{Hg}, \mathrm{Zn}, \mathrm{Ag}$, and moderately rich in As (table 3).

\section{DISCUSSION AND CONCLUSIONS}

The precise nature of oreshoot control and genesis in ore deposits, as Bateman (1942) discussed, is unsolved in most cases; however, interpretation of the detailed geology of oreshoots and comparison of characteristics of oreshoot types to one another, and to the main orebody, can shed light on how oreshoots, and the orebody as a whole, formed. Textural relations among gangue and ore minerals, wall rock alteration assemblages, and zoning characteristics of the mineralized rocks indicate reaction of ore fluid with wall rocks through time (see Ferdock and others, 1997; Woitsekhowskaya and Peters, 1998). Therefore, spatial zoning of mineralogically distinct oreshoots in the orebody is likely to be related to geologic events that were present during the evolution of this fluid and together represent the oreforming process.

Strong field and laboratory evidence exists at Betze for the introduction of Aubearing fluid during deformation, not unlike interaction of fluids with localized deformation events in the upper crust that have been documented elsewhere (McClay, 1977; Henley, 1973; Henley and Ethridge, 1994; Hickman and others, 1994; Logan and Decker, 1994). These events commonly are regarded as extensions of deep crustal fluid-deformation interactions in the ore-forming environment (see Fyfe and others, 1978; Ethridge and others, 1983; O’Hara, 1998; Hyndman, 1994). The Betze orebody most likely formed during a tectonic event after the Late Jurassic $\left(\mathrm{D}_{3}\right.$, table 1$)$ that was accompanied by significant fluid flow. Faulting, shearing, and gouge development along less competent illite-clay altered and decalcified zones - followed by continued hydrothermal alteration-increased porosity further and enhanced fluid flux along the DDZ, and may also have developed zones of hydrofracture (Byerlee and Brace, 1972; Phillips, 1972, 1986; Engelder, 1974). Fluctuations in pressure and temperature also caused variation in fluid chemistry across the DDZ. 
Ore textures in the orebody also indicate ore formation under elevated fluid pressures in a dynamic environment. The illite-clay-pyrite oreshoots contain As-rich pyrite, illite and quartz gangue along bedding planes or phyllonitic seams. Veins and veinlets are rare and open-space-filling textures-more typical of shallow, low-pressure environments (Bodnar and others, 1985; Berger and Bethke, 1985) — are generally lacking. Fibrous textures and pointed terminations of veinlets - such as are locally present in the realgar- and orpimentbearing oreshoots - are characteristic of crack-seal mechanisms (Secor, 1965; Beach, 1977; Ramsay, 1980b) that formed in deep settings under high fluid pressures in the ductile-brittle environment (Sibson and others, 1988; Sibson, 1990). The oreshoots contain, or are separated by, complex cataclastic mixtures of crushed and brecciated wall rock, gouge, phyllonite, illite-clay seams, and altered wall rock, all of which indicate a complex dynamic ore forming system. Textural variations among the oreshoots along the host DDZ conduit also suggest that local pressure and temperature fluctuations in the ore fluid may have occurred in conjunction with deformation and dilation.

Patterns of alteration zoning in the orebody define a large zone where fluid flow was high defined by a central high-grade core of gold-associated illite-clay and silica alteration in and adjacent to the high-grade oreshoots that is surrounded by lower-grade zone $\mathrm{s}$ of decalcification and weak illite-clay alteration. Restriction of alteration to narrow illite-clayrich selvages around unaltered marble or calc-silicate rock phacoids implies that fluid flow favored permeable deformed zones in the DDZ. Alternating complex layers of illite-clay alteration and silicification may be due to: (1) distinct, separate hydrothermal events; (2) mixing of multiple fluids; (3) evolution of a single fluid through fluid-rock interaction; or most likely (4) strong lithologic or deformation fabric control of fluid movement and hydrothermal alteration and mineralization.

Gold deposition in the Betze orebody resulted from hydrothermal fluid reactions with the host lithologies, starting with decarbonatization, which resulted in increases in porosity and permeability. Alteration proceeded through time from fresh, unaltered rock, through progressive decarbonatization, then to argillic alteration, and finally to silicification. The main gold deposition stage involved iron sulfide and arsenic deposition, a transition from illite to kaolinite deposition with pulses of quartz deposition. These events were accompanied by phyllonite development, fault gouge, dissolution-collapse, and tectonic brecciation.

Pre-ore deformational fabrics or textures, such as broad folding, and formation of sedimentary and collapse breccias, can be thought of as structural ground preparation, whereas syn-ore forming deformational textures, such as phyllonite development and mesoscopic shear folding, were due to conduit-fluid interaction, similar to processes in kinetic oreshoots proposed by Poulsen and Robert (1989). The stages of ground preparation present in textures in the oreshoots are: pre-ore stage deformation $\left(D_{1}\right.$ to $D_{2}$, table 1$)$, decalcification, and chemical preparation of sheared rocks in the DDZ, and syn- and post-ore shearing, shear folding and faulting $\left(\mathrm{D}_{3}\right.$, table 1$)$ that resulted in development of complex ore deposition sites. Interaction of the syndeformational shear folding with the evolving fluid 
and resulting paragenesis was responsible for the distribution and zoning of the various types of oreshoots as well as the surrounding ore.

Zones of illite-clay alteration in the upper parts of the Betze orebody played an important role in development and distribution of the oreshoots. Many illite-clay-pyrite ores contain phyllonitic seams and breccias accompanied by tight, mesoscopic folds that parallel the strike of the DDZ, suggesting that deformation accompanied or closely followed alteration and mineralization. Similar illite crystallinity indices of illite in phyllonite, fault gouge zones, and undeformed altered sedimentary beds and phacoids suggest that these rocks may all have been altered under similar P-T conditions (see also Pollastro, 1993), which also is compatible with interaction between wall rock and the hydrothermal fluid during deformation. It is likely that these hydrated minerals in the shear zones and faults enhanced shearing. Argillization also may have influenced the evolution of the fluid by releasing or absorbed saline fluids, and planar illite-clay phyllonitic zones may have formed local pressure seals that affected channeling of fluids (Wang and Mao, 1979; Wang and others, 1979; Moore and others, 1989).

Although local offset can be demonstrated inside the deformed, WNW-trending zone that contains the Betze orebody and the DDZ, evidence of major throw and shear sense across this zone are equivocal. Lack of significant offset across this intensely deformed zone indicates that a direct correlation between the thickness of the zone and displacement does not exist (see Robertson, 1983; Hull, 1988; Walsh and Watterson, 1988, 1989). This suggests that deformation, and accompanying hydrothermal alteration and mineralization, were confined to a finite volume adjacent to the contact of the Goldstrike stock and that folding and shearing were accommodated by dissolution, collapse, and brecciation within this volume of intensely disturbed rock.

Lithologic contacts influenced development and distribution of oreshoots. Many oreshoots are present on both sides of contacts between the Rodeo Creek unit and Popovich limestone and the Popovich limestone and Goldstrike diorite. The plunge of the illite-claypyrite, realgar- and orpiment-bearing and stibnite-bearing siliceous oreshoots coincides with the intersection of the DDZ and these lithologic contacts, similar to lithologic control discussed by Reid and others (1975) and Treagus (1988). Intersection of the DDZ and the keel of the Peters syncline is spatially associated with rutile-bearing siliceous oreshoots that plunge parallel to the intersection of these structures. Deformation and rotation of the previously deformed keel $\left(\mathrm{D}_{1}\right.$ or $\mathrm{D}_{2}$ ?) of the Peters syncline by the $\mathrm{DDZ}\left(\mathrm{D}_{3}\right)$ caused an increase in porosity and fracture density, thereby providing conduits for ore fluids.

Permeability and dissolution in the DDZ are inferred to have been similar to that documented and discussed for most common shear zones by Brace (1980), Bell (1981), Logan and Decker (1994), and Scholz and Anders (1994). Porosity networks in shear zones usually take the form of cracks or tubes along the volume of rock in the shear zone (Gerraund and others, 1995), and these networks may be partially manifested by the geometry of the oreshoots in the Betze orebody. Secondary faulting in the DDZ during the mineralizing event also may have generated tensional fields that localized oreshoots, because geometric complexity and multiple movement in splayed areas can result in local tensile stresses 
(Lajtai, 1969; Gamond, 1987). This may have caused fluid pressure and stress gradients to develop throughout the fault network, especially in the competent stibnite-bearing siliceous oreshoots hosted mainly by calc-silicate rocks, enhancing permeability and channeling fluids of variable composition through breccia and interconnected parts of the fault network.

Fluid-wall rock interaction affected fluid flux and fluid chemistry along the DDZ that caused chemical gradients between calcareous, siliceous, carbonaceous and dioritic rocks that further produced chemical changes in the ascending fluid that crossed these lithologic contacts (see also Fyfe and Kerrich, 1984). Chemical reactions, pH, and temperature changed around individual oreshoots as the fluid flowed into the adjacent rocks. Channeling of fluid into separate, permeable structural zones and wall rock types isolated pockets of fluid and caused them to evolve independently due to separate wall rock interaction and local temperature and pressure conditions.

Gold deposition and decarbonatization resulted from fluid-rock reactions between the ore fluid and the host rock as small changes occurred in temperature and rock-fluid ratio, according to geochemical modeling by Woitsekhowskaya and Peters (1998). This modeling shows that chemical reactions accompanied strain and consisted of (1) dissolution of diagenetic clay minerals, (2) silica-leaching and silica-fixation, and (4) carbonate dissolution. Fluid-rock interaction under strain led first to volume loss and formation of early kaolinite+pyrite+graphite and late illite-clay-pyrite mineral assemblages, which further weakened the rock mass, providing the favorable sites where major phyllonite seams could form and propagate. The relatively low $\mathrm{pH}$ of the reactions and accompanying dissolution produced an aqueous phase with $\mathrm{Si} / \mathrm{Al}$ ratios higher than those in the dissolving host rock, and therefore, aqueous silica concentration increased due to alteration of primary clay minerals in the host rock. This finally led to clay mineral deposition, predominantly illite, dissolution and concurrent precipitation of quartz, which strengthened the rock mass, producing late brittle brecciation in the silicified parts and late gouge development in the unsilicified illite-clay rich parts of the orebody.

The deposition of $\mathrm{Au}, \mathrm{Fe}, \mathrm{As}$, and $\mathrm{Sb}$ minerals during the later stages of mineralization require that the ore fluid reacted at relatively high aqueous silica values with already formed alteration-mineral assemblages (see Woitsekhowskaya and Peters, 1998). Silica-leaching reactions did not result in saturation of the system with respect to quartz, because the bulk of the host rocks are relatively silica-poor. Gold that remained in the fluid and was not depleted during formation of As-rich pyrite also precipitated in the realgar- and orpiment-bearing and stibnite-bearing siliceous oreshoots and was accompanied by the replacement of calcite by quartz. Gold and arsenic were consistently depleted from the inflowing fluid as it reacted with altered wall rock. Realgar and orpiment precipitated at the lower temperatures, and eventually stibnite precipitated due to decrease in sulfur activity and temperature. Leaching reactions were not important during development of the realgar- and orpiment-bearing and stibnite-bearing siliceous oreshoots and the mineralizing process was not chemically aggressive. This enabled a preservation of textures in undeformed areas during the course of replacement. The geologic expression of these relations is the interplay between changing mineral solubility and depletion of metals in the system. Late deposition of native gold, mercury, base-metals and silver minerals precipitated in the polymetallic 
oreshoots. Zoning of the oreshoots indicates that temporal and spatial chemical changes allowed precipitation of different minerals in different oreshoots as the fluid evolved and cooled.

Ore textures, gouge, phyllonitic shear zone rocks, alteration style, and isotopic and fluid-inclusion data (see also Hofstra, 1997; Hofstra and Rye, 1998) all point to a weakly to moderately saline fluid that ascended and cooled in the DDZ and participated in local deformation in this zone. Evidence for more than one fluid is generally lacking, although later influx of meteoric water in a waning, uplifted, collapsing system is possible. Changing conditions in the DDZ, such as wall-rock reactions, and declining P-T are responsible for fluid variation, and account for most metal deposition. Changes to the deposition sites of ore and alteration minerals in the Betze orebody occurred both prior to ore formation and during dynamic interaction of the gold-bearing fluid with the wall rock. All of these processes promoted oreshoot growth and zoning.

\section{ACKNOWLEDGMENTS}

We would like to thank Barrick Goldstrike Mines Inc. for permission to publish the results of our studies. Ferdock also would like to thank the U.S. Geological Survey, Barrick Goldstrike Mines Inc., and the Ralph J. Roberts Center for Research in Economic Geology, Geological Sciences Department, Mackay School of Mines, University of Nevada, Reno for funding of field and laboratory work. Access to Barrick Goldstrike property and was facilitated by Keith $\mathrm{H}$. Bettles, Eric A. Lauha, and Jeff A. Volk who also provided discussion and support. XRD of some clay minerals was performed by Ali Ucruum at Mackay School of Mines; other XRD analyses were conducted at the Barrick Goldstrike laboratory. SEM photographs are by Robert L. Oscarson, USGS Menlo Park. Help with photography was provided by Mall J. Hibbard and Zhiping Li. Reviews of early drafts of the manuscript by Howard J. McCarthy Jr. , David A. John, Dennis P. Cox and Ted G. Theodore are much appreciated.

\section{REFERENCES}

Arehart, G. B., 1996, Characteristics and origin of sediment-hosted gold deposits: a review: Ore Geology Reviews, v. 11, p. 383-403.

Arehart, G.B., Chryssoulis, S.L., and Kesler, S.E., 1993a, Gold and arsenic in iron sulfides from sediment-hosted disseminated gold deposits: Implications for depositional processes: Economic Geology, v. 88, p. 171-185.

Arehart, G.B., Eldridge, C.S., Chryssoulis, S.L., Kesler, S.E., 1993a, Ion microprobe determination of sulfur isotope variations in iron sulfides from the Post/Betze sediment-hosted gold deposit, Nevada, USA: Geochemica et Cosmochimica Acta, v. 57, p. 1505-1519.

Arehart, G.B., Foland, K.A., Naeser, C.W., and Kesler, S.E., 1993c, ${ }^{40} \mathrm{Ar} /{ }^{39} \mathrm{Ar}, \mathrm{K} / \mathrm{Ar}$, and fission track geochronology of sediment-hosted disseminated gold deposits at PostBetze, Carlin trend, northeastern Nevada: Economic Geology, v. 88, p. 622-646. 
Armstrong, A.K., Theodore, T.G., Kotlyar, B.B., Lauha, E.G., Griffin, G.L., Lorge, D.L., and Abbott, E.W., 1997, Preliminary facies analysis of Devonian authochthonous rocks that host gold along the Carlin trend, Nevada, in Vikre, Peter, Thompson, T.B., Bettles, K., Christensen, Odin, and Parratt, R., eds., Carlin-type Gold Deposits Field Conference: Economic Geology Guidebook Series, vol. 28, p. 53-74.

Bakken, B.M., and Einaudi, M.T., 1986, Spatial and temporal relations between wall-rock and gold mineralization, main pit, Carlin gold mine, Nevada, in MacDonald, A.J., Gold '86, Willowdale, Ontario: Konsult International Inc., p. 388-403.

Bakken, B.M., Hochella, M.R., Jr., Marshall, A.F., and Turner, A.M., 1989, High resolution microscopy of gold in unoxidized ore from the Carlin mine, Nevada: Economic Geology, v. 84, p. 171-179.

Bateman, A. M., 1942, Economic Mineral Deposits: John Wiley and Sons, New York, 898 p.

Beach, A., 1977, Vein array, hydraulic fractures and pervasive flysch sequence, S.W. England: Techtonophysics v. 40, p. 201-225.

Bell, T.H., 1981, Foliation development-The contribution, geometry and significance of progressive, bulk, inhomogeneous shortening: Tectonophysics, v. 75, p. 273-296.

Berger, B.R. and Bethke, P.M. 1985, Geology and Geochemistry of Epithermal Systems: Reviews in Economic Geology v. 2, Society Economic Geology, 298 p.

Berry, A.R., 1992, A geological study of the Betze gold deposit, Eureka County, Nevada: M.S. Thesis, University of Nevada, Reno, 173 p.

Bettles, K.H., 1989, Gold deposits of the Goldstrike Mine, Carlin Trend, Nevada: Society of Mining Engineers Preprint, 89-158, 14 p.

Bettles, K.H., and Lauha, E.A., 1991, Gold deposits of the Carlin Trend, Nevada: World Gold '91, Forum on Technology and Practice, Second Australian Institute of Mining and Metallurgy-Society of Mining and Metallurgy Joint Conference, 21-26 April, Cairns, Australia, p. 251-257.

Blanchard, R., 1931, Use of ore guides: Engineering Mining Journal, v. 131, p. 174.

Bodnar, R.J., Reynolds, T. J. and Kuehn, C.A., 1985, Fluid-inclusion systematics in epithermal systems, in Berger, B.R., and Bethke, P.M., eds., Geology and Geochemistry of Epithermal Systems, Society Economic Geology Reviews, v. 2, p. 73-98.

Brace, W.F., 1980, Permeability of crystalline and argillaceous rocks: International Journal Rock Mechanics Mineral Science, v. 1, p. 241-251.

Byerlee, J.D. and Brace, W.F., 1972, Fault stability and pore pressure: Bulletin Seismology Society of America, v. 62, p. 656-660.

Campbell, B.C., 1994, The geology of the Post oxide deposit, Goldstrike Mine, Eureka County, Nevada: Colorado State University, M.S. thesis, 111 p.

Christensen, O. D., 1993, Carlin trend geologic overview, in Christensen, O.D., ed., Gold Deposits of the Carlin Trend, Nevada: Society of Economic Geologists Guidebook Series, v. 18, p. 3-26.

1996, Carlin trend geologic overview, in Green, S.M., and Strusacker, E., eds., Geology and ore deposits of the American Cordillera Road Trip B, Structural Geology of the Carlin Trend: Geological Society of Nevada Field Trip Guidebook Compendium, 1995, Reno/Sparks, Nevada, p. 147-156. 
Clode, C.H., 1993, Breccias of the Deep Star gold deposit, Eureka County, Nevada, in Williams, C., ed., Symposium on Northeastern Nevada Breccia Bodies: Geological Society of Nevada-Elko Chapter, unpaginated.

Cluer, J. K, Cellura, B.R., Keith, S.B, Finney, S.C., and Bellert, S.J., 1997, Stratigraphy and structure of the Bell Creek Nappe (Antler Orogen), Ren Property, Northern Carlin Trend, Nevada, in Perry, A.J, and Abbott, E.W., eds., The Roberts Mountains Thrust, Elko and Eureka Counties, Nevada: Nevada Petroleum Society 1997 Field Trip Guidebook, Reno, Nevada, p. 41-54.

Dazhi, Jiang, and White, J.C., 1995, Kinematics of rock flow and the interpretation of geological structures, with particular reference to shear zones: Journal Structural Geology, v., 17, no. 9, p. 1249-1265.

Drews-Armitage, S.P., Romberger, S.B., Whitney, C.G., 1996, Clay alteration and gold deposition in the Genesis and Bluestar Deposits, Eureka County, Nevada: Economic Geology, v. 91, p. 1383-1393.

Emsbo, Poul, Hutchinson, R.W., Hofstra, A.H., Volk, J.A., Bettles, K.H., Baschuk, G.J., Collins, T.M., Lauha, E.A., and Borhauer, J.L., 1997, Newly discovered Devonian sedex-type base and precious metal mineralization, northern Carlin trend, Nevada, in Vikre, P, Thompson, T.B., Bettles, K., Christensen, O., and Parrat, R., eds., CarlinType Gold Deposits Field Conference: Society of Economic Geology, Guidebook Series v. 28, p. 109-118.

Engelder, J.T., 1974, Cataclasis and the generation of fault gouge: Geological Society America. Bulletin, v. 85, p. 1515-1522.

Etheridge, M.A., Wall. V.J., and Vernon, R. H., 1983, The role of the fluid phase during regional metamorphism and deformation: Journal Metamorphic Geology, v. 1, p. 205-226.

Evans, J.G., 1974a, Geologic Map of the Rodeo Creek NE Quadrangle, Eureka County, Nevada: U.S. Geological Survey, Geologic Quadrangle Map, GQ-1116, scale $1: 24,000$.

1974b, Geologic map of the Welches Canyon quadrangle, Eureka County, Nevada: U.S. Geological Survey Geol. Quad. Map GQ-1117, scale 1:24,000 1980, Geology of the Rodeo Creek NE and Welches Canyon quadrangles, Eureka County, Nevada: U.S. Geological Survey Bulletin 1473, 81 p.

Evans, J.G., and Cress, L.D., 1972, Preliminary geologic map of the Schroeder Mountains Quadrangle, Nevada: U.S. Geological Survey Miscellaneous Field Studies Map MF-324, 1 sheet, scale 1:24,000.

Evans, J.G., and Mullens, T.E., 1976, Bootstrap window, Elko and Eureka Counties, Nevada: U.S. Geological Survey Journal of Research, v. 4, no. 1, p. 119-125 .

Evans, J.G., and Theodore, T.G., 1978, Deformation of the Roberts Mountains allochthon in north-central Nevada: U.S. Geological Survey Professional Paper 1060, 18 p.

Ferdock, G.C., Peters, S. G., Leonardson, R.W., and Larson, L.T., 1996, Alteration geochemistry at the Goldstrike Mine, Eureka County, Nevada [abs.]: Geological Society of America Abstracts with Programs, 1996 Annual Meeting, p. A-94.

Ferdock, G.C., Castor, S.B., Leonardson, R.W., and Collins, T., 1997, Mineralogy and paragenesis of ore stage mineralization in the Betze gold deposit, Goldstrike Mine, Eureka County, Nevada, in Vikre, Peter, Thompson, T.B., Bettles, K., Christensen, 
Odin, and Parratt, R., eds., Carlin-type Gold Deposits Field Conference, Economic Geology Guidebook Series, v. 28, p. 75-86.

Fleet, M.E., and Mumin, Hamid, 1997, Gold-bearing As-rich pyrite and marcasite and arsenopyrite from Carlin Trend gold deposits and laboratory studies: American Mineralogist, v. 82, p. 182-187.

Fyfe, W.S., Price, W.J., and Thompson, A.B., 1978, Fluids in the Earth's Crust: Elsevier, New York, $383 \mathrm{p}$.

Fyfe, W.S., and Kerrich, R., 1984, Gold natural concentration processes, in Foster, R.P., ed., Gold '82. The Geology. Geochemistry and Genesis of Gold Deposits: Geological Society Zimbabwe Special Publication 1, p. 99-127.

Gamond, J. F., 1987, Bridge structures as a sense of displacement criteria in brittle fault zones: Journal Structural Geology, v. 9, p. 609-620.

GŽraud, Yves, Caron, Jean-Michel, and Favre, Pierre, 1995, Porosity network of a ductile shear zone: Journal of Structural Geology, v. 17, no. 12, p. 1757-1769.

Griffin, G., Lauha, E, and Volk, J., 1993, The breccias of the Meikle deposit, in Williams, C., ed., Symposium on Northeastern Nevada Breccia Bodies: Geological Society of Nevada-Elko Chapter, unpaginated.

Groff, J., 1996, ${ }^{40} \mathrm{AR} /{ }^{39} \mathrm{Ar}$ Geochemistry of gold mineralization and origin of auriferous fluids for the Getchell and Twin Creeks Mines, Humboldt County, Nevada: New Mexico Institute of Mining and Technology, Ph.D. dissertation, $290 \mathrm{p}$.

Hausen, D.M., and Kerr, P.F., 1966, Fine gold occurrence at Carlin, Nevada: Economic Geology, v. 61, no. 8, p. 1468-1469.

1968, Fine gold occurrence at Carlin, Nevada, in Ore deposits of the United States, 1933-1967 (Graton-Sales Volume): American Institute of Mining, Metallurgy and Petroleum Engineers, New York, v. 1., p. 908-940.

Henley, R.W., 1973, Some fluid dynamics and ore genesis: Transactions Institute Mining Metallurgy, v. 82, p. B1-B8.

Henley, R.W., and Ethridge, M.A., 1994, Syn-deformational gold transport and deposition in brittle-ductile shear zones-some chaotic thoughts, in Hickman, Stephen, Sibson, Richard, and Bruhn, Ronald, eds., Proceedings of Workshop LXIII, The Mechanical Involvement of Fluids in Faulting: 6-10 June, 1993: U.S. Geological Survey OpenFile Report 94-228,p. 204-215.

Hickman, Stephen, Sibson, Richard, and Bruhn, Ronald, eds., 1994, Proceedings of Workshop LXIII, The Mechanical involvement of fluids in Faulting: 6-10 June, 1993: U.S. Geological Survey Open-File Report 94-228, 615p.

Hofstra, A.H., 1997, Isotopic composition of sulfur in Carlin-type gold deposits: implications for genetic models, in Vikre, Peter, Thompson, T.B., Bettles, K., Christensen, Odin, and Parratt, R., eds., Carlin-type Gold Deposits Field Conference, Economic Geology Guidebook Series, vol. 28, p. 119-131.

Hofstra, A.H., Leventhal, J.S., Northrop, H.R., Landis, G.P., Rye, R.O., Birak, D.J., and Dahl, A.R., 1991, Genesis of sediment-hosted disseminated-gold deposits by fluid mixing and sulfidization: chemical-reaction-path modeling of ore-depositional processes documented in the Jerritt Canyon district, Nevada: Geology, v. 19, p. 3640. 
Hofstra, A.H., and Rye, R.O., 1998, $\delta \mathrm{D}$ and $\delta^{18} \mathrm{O}$ data from Carlin-type gold depositsImplications for genetic models, in Tosdal, R.M., ed., Contributions to the Gold Metallogeny of Northern Nevada: U.S. Geological Survey Open-File Report 98-338, p. 202-210.

Hulin, C.D., 1929, Structural control of ore deposits: Economic Geology, v. 24, p. 15-49.

Hull, J., 1988, Thickness-displacement relationship for deformation zones: Journal Structural Geology, v. 10, p. 431-435.

Hyndman, R.D., 1994, Widepread fluids in the lower crust: a source to crystal penetrating faults, in Hickman, Stephen, Sibson, Richard, and Bruhn, Ronald, eds., Proceedings of Workshop LXIII, The Mechanical Involvement of Fluids in Faulting: 6-10 June, 1993: U.S. Geological Survey Open-File Report 94-228,p. 178-189.

Ilchick, R.P., and Barton, M.D., 1997, An amagmatic origin of the Carlin-type gold deposits: Economic Geology, v. 92, no. 3, p. 269-288.

Ketner, K.B., 1987, Post-Early Triassic, pre-middle Eocene folds and thrust faults, northern Adobe Range, Nevada: Geological Society of American Centennial FieldCordilleran Section, no. 21, p. 91-94.

1998, The nature and timing of tectonism in the Western Facies terrane of Nevada and California-An outline of evidence and interpretation derived from geologic maps of key areas: U.S. Geological Survey Professional Paper 1592, 19 p.

Ketner K.B., and Alpha, A.G., 1992, Mesozoic and Tertiary rocks near Elko, Nevadaevidence for Jurassic to Eocene folding and low-angle faulting: U.S. Geological Survey Bulletin 1988-C, 13 p.

Ketner, K.B., Murchey, B.L., Stamm, R.G., and Ardlaw, B.R., 1993, Paleozoic and Mesozoic rocks of Mount Icabod and Dorsey Canyon, Elko County, Nevada-evidence for Post-early Triassic emplacement of the Roberts Mountains and Golconda allochthons: U.S. Geological Survey Bulletin 1988-D, 12 p.

Kisch, H.J., 1991, Illite crystallinity: recommendations on sample preparation, x-ray diffraction settings, and interlaboratory samples: Journal Metamorphic Geology, v. 9, p. 665-670.

Kuehn, C.A., 1989, Studies of disseminated gold deposits near Carlin, Nevada: Evidence for a deep geologic setting of ore formation: Ph.D. dissertation, Pennsylvania State University, $395 \mathrm{p}$.

Kuehn, C.A., and Rose, A.W., 1992, Geology and geochemistry of wall rock alteration at the Carlin gold deposit, Nevada: Economic Geology, v. 87, p. 1697-1721.

1995, Carlin gold deposits, Nevada: Origin in a deep zone of mixing between normally pressured and over pressured fluids: Economic Geology, v. 90, p. 17-36.

Lahren, M.M., Schweickert, R.A., Connors, K.A., and Luddington, S., 1995, Allochthonous tectonic units of the central and western Great Basin: Geology and Ore Deposits of the America Cordillera, Reno/Sparks, Nevada, 1995, Program with Abstracts, p. A45.

Lajtai, E.Z., 1969, Mechanics of second order faults and tension gashes: Geological Society American Bulletin, v. 80, p. 2253-2272.

Lamb, J.B., 1995, A petrographic and fluid inclusion study of the Purple Vein and Post-Betze orebodies, Carlin, Nevada: University of Nevada, Las Vegas, M.S., thesis, 161 p.

Lamb, J.B., and Cline, J., 1997, Depths of Formation of the Meikle and Betze/Post deposits, in Vikre, Peter, Thompson, T.B., Bettles, K., Christensen, Odin, and Parratt, R., eds., 
Carlin-type Gold Deposits Field Conference, Economic Geology Guidebook Series, vol. 28, p. 101-108.

Lauha, E.A., and Bettles, K.H., 1993, A geologic comparison of the Post/Betze and Purple vein deposits of the Goldstrike and Meikle Mines, Nevada: Society for Mining, Metallurgy, and Exploration, Preprint 93-170, 20 p.

Leach, B.R., 1993, Breccia characteristics of the Lower Post Orebody, Eureka County, Nevada: in Williams, C., ed., 1993, Symposium on North Eastern Nevada Breccia Bodies: Geological Society of Nevada-Elko Chapter, unpaginated.

Leonardson, R.W., and Rahn, J.E., 1996, Geology of the Betze-Post gold deposits, Eureka County, Nevada, in Coyner, A.R., and Fahey, eds., Geology and Ore Deposits of the American Cordillera: Geological Society of Nevada, Symposium Proceedings, Reno/Sparks, Nevada, April, 1995, p. 61-94.

Logan, J.M., and Decker, C.L., 1994, Cyclic fluid flow along faults, in Hickman, Stephen, Sibson, Richard, and Bruhn, Ronald, eds., Proceedings of Workshop LXIII, The Mechanical Involvement of Fluids in Faulting: 6-10 June, 1993: U.S. Geological Survey Open-File Report 94-228, p. 190-203.

Madrid, R.J., 1987, Stratigraphy of the Roberts Mountains allochthon in north-central Nevada: Stanford University, Ph.D. dissertation, 341 p.

Madrid, R.J., and Bagby, W.C., 1986, Vein paragenesis in selected sediment hosted gold deposit in north-central Nevada: Geological Society of America, Abstracts with Programs, 18, p. 393.

1988, Gold occurrence and its relation to vein and mineral paragenesis in selected sedimentary rock hosted, Carlin-type deposits in Nevada, in Goode, A.D.T., Bosma, L.I., eds., Bicentennial Gold 88: Geological Society of Australia, 22, p. 161-166.

Madrid, R.J., R.J., Poole, F.G., and Wrucke, C.T., 1992, Rocks of the Antler orogen-The Roberts Mountain allochthon, in Burchfiel, B.C., Lipman, P.W., and Zoback, M.L., eds., The Cordilleran Orogen: Conterminous us: Geological Society of America, The Geology of North America, Vol. G-3, p. 28-34.

McClay, K.R., 1977, Pressure solutions and cobble creep in rocks and minerals: a review: Journal Geological Society London, v. 134, p. 570.

McKinstry, H. E., 1941, Structural control of ore deposition in fissure veins: Transactions American Institute Mining Metallurgy Technical Publication 1267, v. 144, p. 65-88. 1955, Structure of hydrothermal ore deposits: Fiftieth Anniversary Volume: Society Economic Geology, p. 170-225.

Moore, D.E., Summers, R., and Byerlee, J. D., 1989, Sliding behavior and deformation textures of heated illite gouge: Journal Structural Geology, v. 11, p. 329-342.

O'Hara, K., 1988, Fluid flow and volume loss during mylonitization: an origin for phyllonite in an overthrust setting, North Carolina, USA. Techtonophysics, v. 156, p. 21-36.

Penrose, R.A.F., Jr., 1910, Some causes of oreshoots: Economic Geology, v. 5, p. 913-933.

Peters, S. G., 1993a. Formation of oreshoots in mesothermal gold-quartz vein deposits, in Haynes, S.J., (ed.), Vein-type ore deposits, Special Vol., Ore Geology Reviews, v. 8, p. 277-301.

1993b, Nomenclature, concepts and classification of oreshoots in vein deposits: Ore Geology Reviews, v. 8, p. 3-22.

1996, Definition of the Carlin trend using orientation of fold axes and applications to ore control and zoning in the central Betze orebody, Betze-Post Mine, in Green, S.M., 
and Struhsacker, E., eds., Geology and ore deposits of the American Cordillera, Trip B-Structural Geology of the Carlin Trend: Geological Society of Nevada Field Trip Guide Compendium, 1995, Reno/Sparks, NV, p. 203-239.

1997a, Structural transect across the north-central Carlin Trend, Eureka County, Nevada: U.S. Geological Survey Open-File Report 97-83, 41 p. 6 sheets, [scale $1: 500]$.

1997b, Structural transect across the southern Carlin Trend, Elko and Eureka Counties, Nevada: U.S. Geological Survey Open-File Report 97-0347, 27 p. 2 sheets, [scale 1:500].

1997c, Structural transect across the central Carlin Trend, Eureka County, Nevada: U.S. Geological Survey Open-File Report 97-55, 40 p., 2 sheets, [scale 1:6,000]. 1997d, The nature of some upper- and lower-plate rocks near the Roberts Mountains thrust, Carlin Trend, in Perry, A.J, and Abbott, E.W., eds., The Roberts Mountains Thrust, Elko and Eureka Counties, Nevada: Nevada Petroleum Society 1997 Field Trip Guidebook, Reno, Nevada, p. 35-40.

1998, Evidence for the Crescent Valley-Independence Lineament, north-central, Nevada, in Tosdal, R.M., ed., Contributions to the Gold Metallogeny of Northern Nevada: U.S. Geological Survey Open-File Report 98-338, p. 106-118.

Peters, S.G., Nash, J.T., John, D.A., Spanski, G.T., King, H. D., Connors, K.A., Moring, B.C., Doebrich, J. L., McGuire, D.J., Albino, G.V., Dunn, V.C., Theodore, T.G., and Ludington, Steve, 1996, Metallic mineral resources in the us Bureau of Land Management's Winnemucca District and Surprise Resource Area, northwest Nevada and northeast California: U.S. Geological Survey Open-File Report 96-712, 147 p., 11 sheets, [scale 1:1,100,000].

Peters, S.G., Leonardson, R.W., Ferdock, G.C., and Lauha, E.A., 1997, Breccia types in the Betze orebody, Goldstrike Mine, Eureka County, Nevada, in Vikre, Peter, Thompson, T.B., Bettles, K., Christensen, Odin, and Parratt, R., eds., Carlin-type Gold Deposits Field Conference: Society Economic Geology Guidebook Series, v. 28, p. 87-100.

Phillips, J.W., 1972, Hydraulic fracturing and mineralization: Journal Geologic Society London, v. 128, p. 337-359.

1986, Hydraulic fracturing effects in the formation of mineral deposits: Transactions Institute Mining Metallurgy, v. 95, p. B17-B24.

Pollastro. R.M., 1993, Considerations and applications of the illite/smectite geothermometer in hydrocarbon-bearing rocks of Miocene to Mississipian age: Clays and Clay Minerals, v. 41, no. 2, p. 119--133.

Poulsen, K.H., and Robert, F., 1989, Shear zones and gold: practical examples from the southern Canadian shield, in Bursnall, J.T., ed., Mineralization and Shear Zones, Geological Association Canada, Short Course Notes, v. 6 p. 239-266.

Prihar, D.W., Peters, S.G., Bourns, F.T., and McKee, E.A., 1996, Geology and gold potential of the Goat Ridge window, Shoshone Range, Lander County, Nevada, in Coyner, A.R., and Fahey, P.L., eds., Geology and Ore Deposits of the American: Geological Society of Nevada Symposium Proceedings, Reno/Sparks, Nevada, April, 1995, p. 485-504.

Radtke, A.S., 1985, Geology of the Carlin gold deposit, Nevada: U.S. Geological Survey Professional Paper 1267, 124p. 
Radtke, A.S., Dickson, F.W, 1975, Carlinite, $\mathrm{Tl}_{2} \mathrm{~S}$, A new mineral from Nevada, American Mineralogist, v. 60, nos. 7-8, p. 559-565.

Radtke, A.S., and Scheiner, B.J., 1970a, Influence of organic carbon on gold deposition at the Carlin and Cortez deposits, Nevada: Geological Society of America, Abstract, v. 2, no. 7, p. 660 .

1970b, Studies of hydrothermal gold deposition (I) , Carlin gold deposit, Nevada: The role of carbonaceous materials in gold deposition: Economic Geology, v. 65, no. 2, p. 87-102.

Radtke, A.S., Heropoulos, C., Fabbi, B.P., Scheiner, B.J., Essington, M., 1972a, Data on major and minor elements in host rocks and ores, Carlin Gold Deposit, Nevada: Economic Geology, v. 67, no. 7, p. 975-978.

Radtke, A.S., Taylor, C.M., Christ, C.L., 1972b, Chemical distribution of gold and mercury at the Carlin Deposit, Nevada: Geological Society of America Annual Meeting, Abstract, v. 4, no. 7, p. 632.

Radtke, A.S., Taylor, C.M., Heropoulos, C., 1973, Antimony bearing orpiment, Carlin gold deposit: Nevada, U.S. Geological Survey Journal of Research, v. 1, no. 1, p. 85-87.

Radtke, A.S., Taylor, C.M., Dickson, F.W., Heropoulos, C., 1974a, Thallium bearing orpiment, Carlin gold deposit, Nevada: U.S. Geological Survey Journal of Research, v. 2, no. 3, p. 341-342.

Radtke, A.S., Taylor, C.M., Erd, R.C., Dickson, F.W., 1974b, Occurrence of lorandite $\mathrm{TlAsS}_{2}$, at the Carlin gold deposit, Nevada: Economic Geology, v. 69, no. 1, p. 121123.

Radtke, A.S., Dickson, F.W., Slack, J.F., Brown, K.L., 1977, Christite, A new thallium mineral from the Carlin gold deposit, Nevada: American Mineralogist, v. 62, nos. 56, p. 421-425.

Ramsay, J.G., 1980a, Shear zone geometry: a review: Journal Structural Geology, v. 2, p. 83-99.

1980b, The crack seal mechanism of rock deformation: Nature, London, v. 284, p. 135-139.

Reid, R.R., Cadday, S.W., and Rankin, T.W., 1975, Primary refraction control of oreshoots, with examples from the Coeur d'Alene district, Idaho: Economic Geology, v. 70, p. 1050-1061.

Resnell, Ricardo, 1990, An anticline trapping model for Carlin-type disseminated gold deposits, in Hausen, D.M., Halbe, D.N., Petersen, E.U., and Tafuri, W.J., eds., Gold '90: Proceedings of the Gold 90 Symposium, Salt Lake City Utah, February 26 to March 1, 1990, p. 21-23.

Roberts, R.J., 1960, Alignment of mining districts in north-central Nevada: U.S. Geological Survey Professional Paper 400-B. p. 17-19.

1966, Metallogenic provinces and mineral belts in Nevada: Nevada Bureau of Mines Report 13, pt. A, p. 47-72.

Roberts, R.J., Hotz, P.E., Gilluly, J., and Ferguson, H.G., 1958, Paleozoic rocks of northcentral Nevada: American Association of Petroleum Geologists Bulletin, vol. 42, no. 12, p. 2813-2857.

Robertson, E.C., 1983, Relationship of fault displacement to gouge and breccia thickness: Mining Engineering, v. 35, p. 1426-1432. 
Robinson, D., Warr, L.N., and Bevins, R.E., 1990, The illite 'crystallinity' technique: a critical appraisal of its precision: Journal Metamorphic Geology, v. 8, p. 33-344.

Rudnicki, J.W., and Hsu, T-C, 1988, Pore pressure changes induced by slip on permeable and impermeable faults: Journal Geophysical Research, v. 93, p. 3275-3285.

Rytuba, J.J., 1985, Geochemistry of hydrothermal transport and deposition of gold and sulfide minerals in Carlin type gold deposits, in Tooker, E.W., ed., Geologic characteristics of sediment and volcanic hosted disseminated gold deposits: Search for an occurrence model: U.S. Geological Survey Bulletin 1646, p. 35-42.

Sampson, T.R., 1993, Alteration and structural paragenetic relations; with emphasis on Mesozoic imbricate thrust faults, Goldstrike Mines area, Eureka County Nevada: Washington State University, M.S. Thesis, 179 p.

Saucier, A.E., 1997, The Antler thrust system in northern Nevada, in Perry, A.J, and Abbott, E.W., eds., The Roberts Mountains Thrust, Elko and Eureka Counties, Nevada: Nevada Petroleum Society 1997 Field Trip Guidebook, Reno, Nevada, p. 1-16.

Scholz, C.H., and Anders, M.H., 1994, The permeability of faults, in Hickman, Stephen, Sibson, Richard, and Bruhn, Ronald, eds., Proceedings of Workshop LXIII, The Mechanical Involvement of Fluids in Faulting: 6-10 June, 1993: U.S. Geological Survey Open-File Report 94-228,p. 247-253.

Schvarov, Y.V., 1976, Calculation of equilibrium composition in a multicomponent heterogeneous system: Academia Nauk SSSR Doklady, v. 229, no. 6, p. 223-225 (in Russian).

Secor, D.T., 1965, Role of fluid pressure in jointing: American Journal Science, v. 263, p. 633-646.

Seedorff, Eric, 1991, Magmatism, extension, and ore deposits of Eocene to Holocene age in the Great Basin - mutual effects and preliminary proposed genetic relationships, in Raines, G.L., Lisle, R.E., Schafer, R.W., and Wilkinson, W.H., eds., Geology and Ore Deposits of the Great Basin, Geologic Society of Nevada Symposium Proceedings, Reno/Sparks, Nevada, April, 1990, p.133-178.

Sibson, R.H., 1977, Fault rocks and fault mechanisms: Journal Geological Society London, v. 133, p. 191-213.

1990, Faulting and fluid flow, in Nesbitt, B.E., ed., Fluids in Tectonically Active Regimes of the Continental Crust: Mineralogical Association Canada Short Course Notes, v. 18, p. 93-109.

Sibson, R.H., Robert. F., and Poulsen, K.H., 1988, High-angle reverse faults, fluid-pressure cycling, and mesothermal gold-quartz deposits: Geology, v. 16, p. 551-555.

Silberling, N.J., 1975, Age relationships of the Golconda thrust fault, Sonoma Range, northcentral Nevada: Geological Society of America Special Paper 163, 28p.

Silberling, N.J., and Roberts, R.J., 1962, Pre-Tertiary stratigraphy and structure of northwestern Nevada: Geological Society of America Special Paper 72, 58p.

Smith, M.R., and Sharon, R.P., 1994, Engineering geology of Barrick Goldstrike Mines' Betze Pit: Mining Engineering, p. 29-33.

Stenger, D.P., Kesler, S.E., Peltonen, D.R., and Tapper, C.J., 1998, Deposition of gold in Carlin-type deposits: the role of sulfidation and decarbonation at Twin Creeks, Nevada: Economic Geology, v. 93, no. 2, p. 216-223.

Stewart, J.H., and Carlson, J.E., 1976, Geologic map of north-central Nevada: Nevada Bureau of Mines and Geology, Map 50, [scale 1:250,000]. 
Tanaka, Hidemi, 1992, Cataclastic lineations: Journal of Structural Geology, v. 14, no. 10, p. 1239-1252.

Teal, Lewis, and Jackson, Mac, 1997, Geologic overview of the Carlin trend gold deposits and descriptions of recent deep discoveries, in Vikre, Peter, Thompson, T.B., Bettles, K., Christensen, Odin, and Parratt, R., eds., Carlin-type Gold Deposits Field Conference: Society Economic Geology Guidebook Series, v. 28, p. 3-38.

Theodore, T.G., Armstrong, A.K., Harris, A.G., Stevens, C.H., and Tosdal, R.M., 1998, Geology of the northern terminus of the Carlin trend, Nevada: links between crustal shortening during the Late Paleozoic Humboldt orogeny and north-east-striking faults, in Tosdal, R.M., ed., Contributions to the Gold Metallogeny of Northern Nevada: U.S. Geological Survey Open-File Report 98-338, p. 69-105.

Thoreson, R.F., 1993, Geology of the Post Deposit, Eureka County, Nevada, in Christensen, O.D., ed., Gold Deposits of the Carlin Trend, Nevada: Society of Economic Geologists Guidebook Series, v. 18, p. 50-66.

Thorman, C.H., and Christensen, Odin, 1991, Geologic settings of gold deposits in the Great Basin, western United States, in Ladeira, E.R., ed., Proceedings of Brazil Gold '91, An International Symposium on Geology of Gold: Belo Horizonte, 1991, A.A. Balkena, Rotterdam, p. 65-76.

Thorman, C.H., Ketner, K.B., Brooks, W.E., Snee, L.W., and Zimmerman, R.A., 1991a, Late Mesozoic-Cenozoic tectonics in northeastern Nevada, in Raines, G.I., Lisle, R.W., Schafer, R.W., and Wilkinson, W.H., eds., Geology and Ore Deposits of the Great Basin, Symposium Proceedings: Geological Society of Nevada, Reno/Sparks, p. 2545.

Thorman, C.H., Ketner, K.B., Snoke, A.W., Brooks, W.E., and Mueller, K.J., 1991b, Evidence for the involvement of the Roberts Mountains allochthon in Mesozoic tectonics and its effect on mineral deposit and petroleum accumulation models in northeast Nevada, Field Trip 13, in Buffa, R.H., and Coyner, A.R., eds., Geology and Ore Deposits of the Great Basin-Field Trip Guidebook Compendium-Great Basin Symposium, April, 1990: Geological Society of Nevada, Reno/Sparks, p. 869-905.

Tomlinson, A,J., 1990, Biostratigraphy, stratigraphy, sedimentary petrology, and structural geology of the upper Paleozoic Golconda allochthon, north-central Nevada: Ph.D dissertation, Stanford University, Stanford California, 492p.

Tosdal, R.M., ed., 1998, Contributions to the Gold Metallogeny of Northern Nevada: U.S. Geological Survey Open-File Report 98-338, 290 p.

Treagus, S.H., 1988, Strain refraction in layered systems: Journal Structural Geology, v. 10, p. 517-527.

Vikre, Peter, Thompson, T.B., Bettles, K., Christensen, Odin, and Parratt, R., eds., 1997, Carlin-type Gold Deposits Field Conference, Economic Geology Guidebook Series, vol. 28, 287 p.Volk, J.A., and Lauha, E.A., 1993, Structural controls on mineralization at the Goldstrike property, Elko and Eureka Counties, Nevada: Geological Society of America Abstracts with Programs, v. 23, no. 2, p. 106.

Volk, J.A., Lauha, E., Leonardson, R.W., and Rahn, J.E., 1996, Structural geology of the Betze-Post and Meikle deposits, Elko and Eureka Counties, in Green, S.M., and Struhsacker, E., eds., Geology and Ore Deposits of the American Cordillera, Trip BStructural Geology of the Carlin Trend, Field Trip Guidebook Compendium, 1995: Geological Society of Nevada, Reno/Sparks, NV, p. 180-194. 
Walck, C.M., 1989, Petrology and petrography of the metamorphic aureole associated with the Deep Post orebody, Eureka County, Nevada: Missouri School of Mines, M.S. thesis, $48 \mathrm{p}$.

Walsh, J.J., and Watterson, J., 1988, Analysis of the relationship between displacements and dimensions of faults: Journal Structural Geology, v. 10, p. 239-247. 1989, Displacement gradients on fault surfaces: Journal Structural Geology, v. 11, p. 307-316.

Wang, C-Y, and Mao, N., 1979, Shearing of saturated clays in rock joints at high confining pressures: Geophysical Research Letters, v. 6, p. 825-828.

Wang, C., Mao, N., and Wu, F.T., 1979, The mechanical property of montmorillonite clay at high pressure and implications on fault behavior: Geophysical Research Letters, v. 6, p. 476-478.

Wells, J.D., and Mullens, T.E., 1973, Gold-bearing As-rich pyrite determined by microprobe analysis, Cortez and Carlin gold mines, Nevada: Economic Geology, v. 68, p. 187201.

White, S.H., Bretan, P.G., and Ruter, E.H., 1986, Fault-zone reactivation: kinematics and mechanisms: Philosophical Transactions Royal Society London, v. A317, p. 81-97.

Williams, C.L., 1992, Breccia bodies in the Carlin Trend, Elko and Eureka Counties, Nevada: Classification, interpretation and roles in ore formation: M.S., thesis, Colorado State University, 213 p.

-ed., 1993, Symposium on North Eastern Nevada Breccia Bodies: Geological Society of Nevada-Elko Chapter, unpaginated.

Woitsekhowskaya, M., and Peters, S.G., 1998, Geochemical modeling of alteration and gold deposition in the Betze deposit, in Tosdal, R.M., ed., Contributions to the Gold Metallogeny of Northern Nevada: U.S. Geological Survey Open-File Report 98338 , p. $211-222$. 